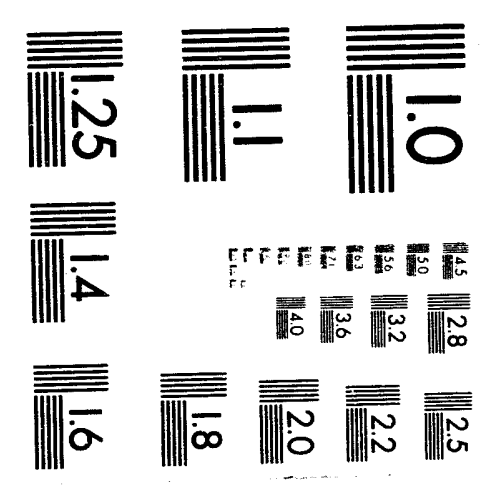



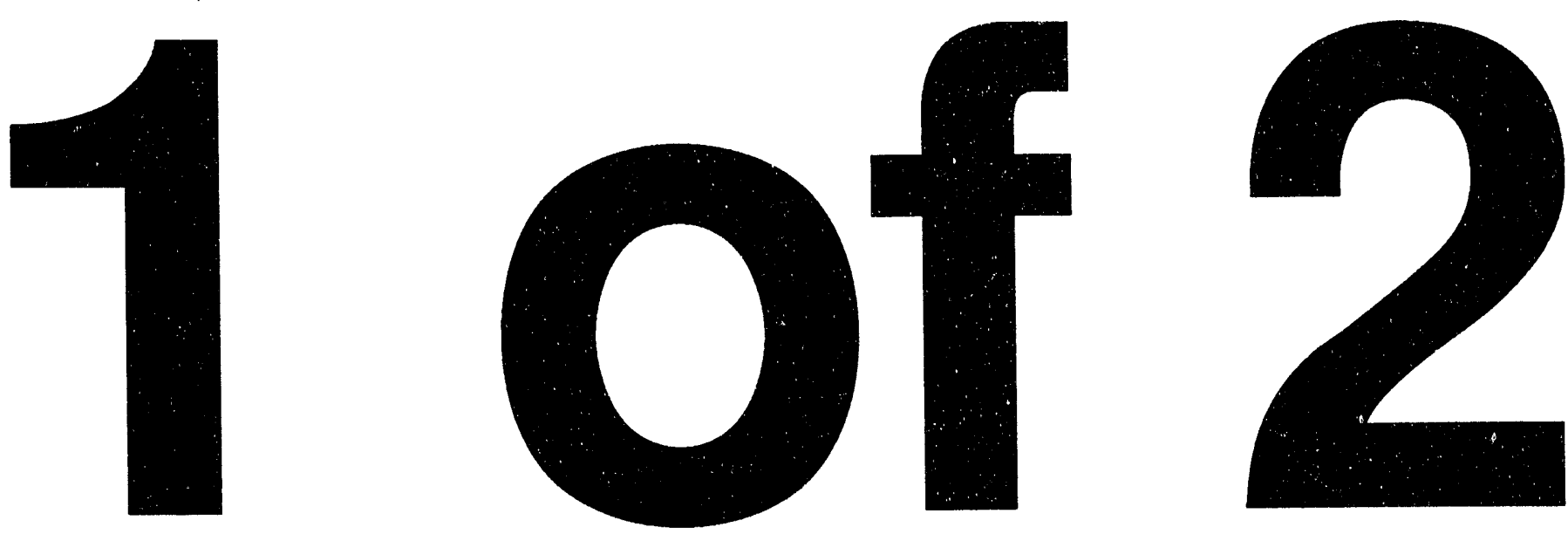


\section{EnVironmental Assessment For}

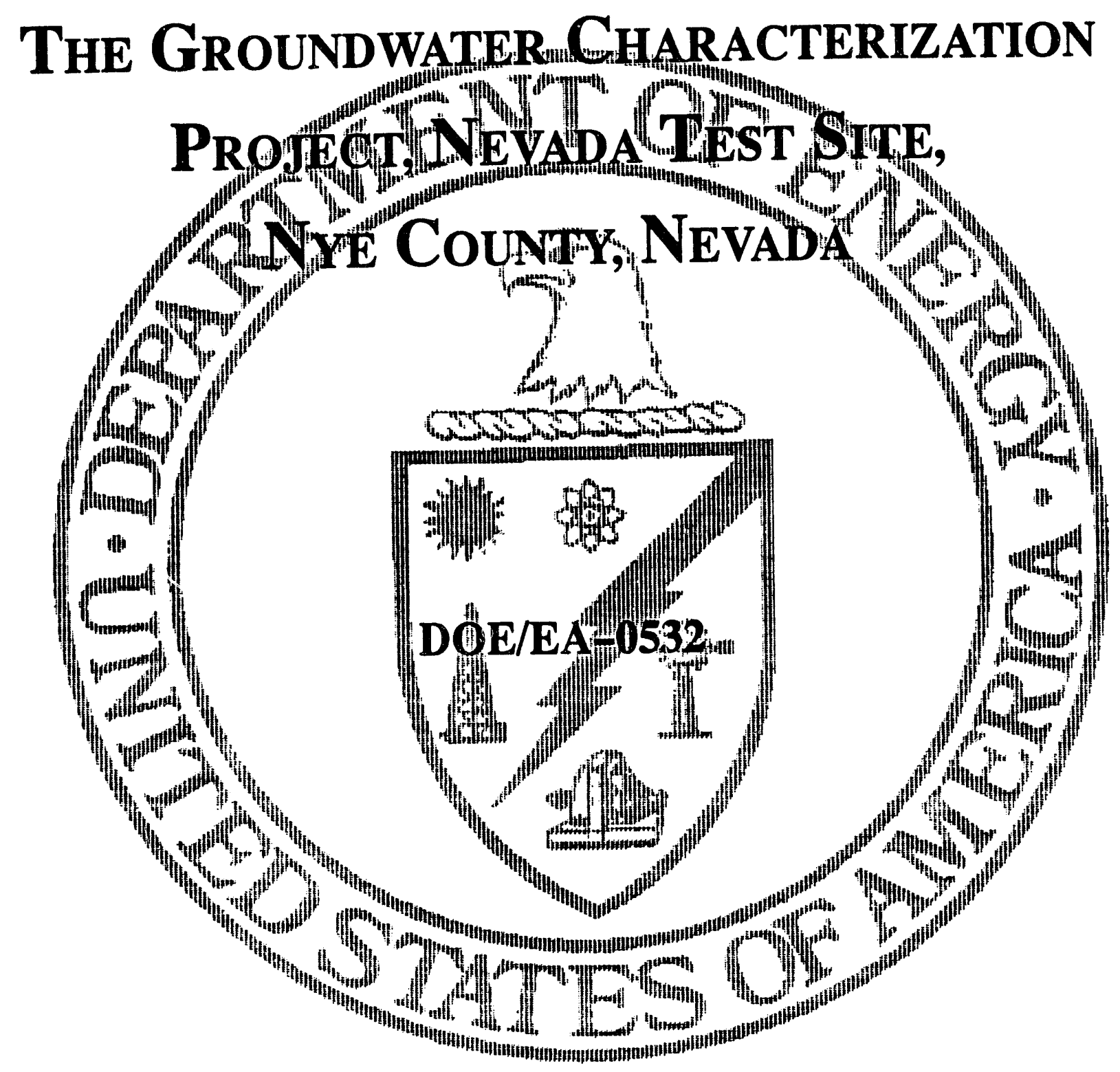

\section{AUGUST 1992}

Rev. 1 


\section{Department of Energy \\ Nevada Operations Office \\ P.O. Box 98518 \\ Las Vegas, NV 89193-8518}

Ron Sparks

Nevada State Clearinghouse

Capitol Complex

Department of Administration

123 West Nye Lane

Carson City, NV 89710

DOE NEVADA OPERATIONS OFFICE FINAL ENVIRONMENTAL ASSESSMENT FOR THE GROUNDWATER CHARACTERIZATION PROJECT, NEVADA TEST SITE, NYE COUNTY, NEVADA

Enclosed for your information are 10 copies of the subject document, Finding of No Significant Impact, and Mitigation Action Plan for the project. Per request, these documents are being provided to the Nevada Agency for Nuclear Projects by this letter.

If you have any questions or concerns regarding this project or the Environmental Assessment or require additional copies of the documents, please contact Frank Maxwell, Environmental Restoration Division, at (702) 295-1050. If you have any questions concerning the National Environmental Policy Act process, please let me know at (702) 295-1433.

EPD:BGG-260

Enclosures:

As stated

cc w/encls:

L. M. Franks, BHPS,

Las Vegas, NV

P. J. Liebendorfer, NDEP, Carson City, NV

Richard Serdoz, NDEP,

Las Vegas, NV

Bill Quinn, NDWR,

Carson City, NV

R. R. Loux, Nuclear Projects,

Carson City, NV

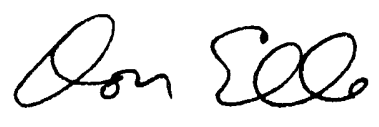

Donald R. Elle, Ph.D., Director

NEPA Compliance Officer 
U.S. FWS, Desert National

Wildlife Range,

Las Vegas, NV

Eloise Hopper, WTC/EM, Nellis AFB, NV

cc w/o encls:

D. W. Rasner, BHPS, Carson City, NV

E. A. Tinney, BHPS,

Las Vegas, NV

Stanley Marshal, BHPS,

Carson City, NV

bcc w/encls:

C. M. Borgstrom, DOE/HQ

(EH-25) FORS (5 copies)

T. P. Longo, DOE/HQ

(EM-452) GTN

L. E. Harris, DOE/HQ

(EM-431) TREV

S. M. Sohinki, DOE/HQ

(DP-43) FORS

bcc w/o encls:

Wendy Dixon, POCD, DOE/YMPO,

Las Vegas, NV

S. R. Mellington, ERD, DOE/NV, Las Vegas, NV 


\author{
DEPARTMENT OF ENERGY \\ FINDING OF NO SIGNIFICANT IMPACT \\ FOR THE GROUNDWATER CHARACTERIZATION PROJECT \\ NEVADA TEST SITE, NYE COUNTY, NEVADA
}

AGENCY: Department of Energy

ACTION: Finding of No Significant Impact (FONSI)

SUMMARY: The U.S. Department of Energy (DOE) proposes to conduct a program to characterize groundwater at the Nevada Test Site (NTS), Nye County, Nevada, in accordance with a 1987 DOE memorandum stating that all past, present, and future nuclear test sites would be treated as Comprehensive Environmental Response, Compensation, and Liability Act (CERCLA) sites (Memorandum from Bruce Green, Weapons Jesign and Testing Division, June 6, 1987). DOE has prepared an environmental assessment (DOE/EA-0532) to evaluate the environmental consequences associated with the proposed action, referred to as the Groundwater Characterization Project (GCP). This proposed action includes constructing access roads and drill pads, drilling and testing wells, and monitoring these wells for the purpose of characterizing groundwater at the NTS. Long-term monitoring and possible use of these wells in support of CERCLA, as amended by the superfund Amendments and Reauthorization Act, is also proposed. The GCP includes measures to mitigate 
potential impacts on sensitive biological, cultural and historicai resources, and to protect workers and the environment from exposure to any radioactive or mixed waste materials that may be encountered. DOE considers those mitigation measures related to sensitive biological, cultural and historic resources as essential to render the impacts of the proposed action not significant, and DOE has prepared a Mitigation Action Plan (MAP) that explains how such mitigations will be planned and implemented.

Based on the analyses presented in the EA, DOE has determined that the proposed action is not a major Federal action significantly affecting the quality of the human environment, within the meaning of the National Environmental Policy Act of 1969 (NEPA). Therefore, preparation of an environmental impact statement is not required and the Department is issuing this FONSI.

FOR FURTHER INFORMATION CONCERNING THE PROPOSED ACTION, OR TO REQUEST COPIES OF THE EA OR MAP, CONTACT:

Leslie A. Monroe Environmental Protection Division Nevada Field office

P.O. Box 98518

Las Vegas, NV 89193-8518

(702) 295-1744 
FOR FURTHER INFORMATION ON THE DOE NEPA PROCESS CONTACT:

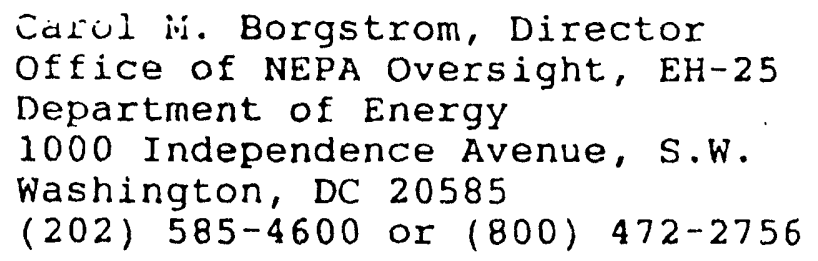

BACKGROUND: Groundwater characterization at the NTS is needed to assess the impacts of past underground nuclear testing on the site's groundwater resources. Testing has produced residual radioactive and hazardous materials in and adjacent to test shot cavities that occur above and within the zone of saturation. The proposed action would provide DOE with valuable data to be used in determining the effects on groundwater of past nuclear weapons testing at the NTS. In addition, these data could be used to assist in future remedial actions. In 1987, DOE determined that all past, present, and future nuclear test sites will be treated as CERCLA sites. (Memorandum from Bruce Green, weapons Testing Division, June 6, 1987). Plans for remedial investigations and feasibility studies (RI/FS) for the NTS are currently being prepared in accordance with regulations (40 CFR 300.61-91) promulgated under CERCLA. RI/FS plans include characterization of the NTS groundwater system.

Because of underground testing programs and the need to ensure geologic containment of test events, the NTS geology has been 
extensively studied and mapped. Geologic data from these studies would be used to determine well sites for the GCP.

PROPOSED ACTION: The proposed action is to drill and sample approximately 100 (90-120) characterization wells at the NTS over the course of 5 to 10 years. The location of each well would be decided upon by a working group of multidisciplinary specialists composed of representatives from the U.S. Geological survey, Lawrence Livermore National Laboratory, Desert Research Institute, DOE, DOE's environmental support services contractor (IT), and Los Alamos National Laboratory. The well sites would be chosen based on a number of factors: hydrogeological information, gaps in current hydrologic knowledge, geologic uncertainty, and regulatory requirements for a groundwater monitoring system. It is anticipated that 3 to 17 wells would be drilled each year for the duration of the project.

The proposed action would provide needed data for estimating groundwater transportation rates and pathways in the groundwater flow systems beneath the NTS. In addition, it would provide data to determine the extent of groundwater contamination, if any. Activities would include: archeological and environmental preconstruction surveys of drill pad and access road sites; improvements or construction of arill site access roads (typical road width would be approximately 7 meters [24 feet]), which would range from less than $1 \mathrm{kilometer}$ to over 10 kilometers 10.6 
miles to over 6 miles]); construction of drill pads measuring approximately 61 meters x 61 meters [200 x 200 feet] with lined sump pits and borrow areas; drilling of wells typically ranging from 760 to 1,200 meters $[2,490$ to 3,940 feet $]$ in depth, and installation of tanks for handling any water that is found to be contaminated during GCP activities. Well casings would be installed in accordance with all applicable CERCLA requirements.

Only 10 of the 100 well sites have been identified. These well sites were identified based on the factors described above and on a critical analysis of the conceptual models of groundwater flow at the NTS. These and all other well sites must satisfy two criteria: 1) maximize data acquisition in the areas identified to be important for understanding regional and local groundwater flow in and around underground test areas; and 2) optimize placement to act as up- or down-gradient monitoring wells. The EA addresses the environmental effects of the GCP by assessing 4 of the 10 characterization well sites and extrapolating the results to the full complement of planned well sites. The EA demonstrates that the 4 well sites are representative of the currently identified and proposed future well sites (locations to be determined) with the exception of those that might be sited in potential desert tortoise habitat.

Consultation with the U.S. Fish and wildlife service is required as a result of the listing of the desert tortoise as a threatened 
species under the Federal Endangered species Act (ESA). In 1991 , DOE prepared a biological assessment (BA) which covers all NTS activities through Fiscal Year 1995 with the exception of the Yucca Mountain Project. In May 1992, a Biological Opinion was obtained from the U.S. Fish and Wildlife Service, which concluded that DOE activities, including the proposed GCP, are not likely to jeopardize the continued existence of the desert tortoise.

If preactivity surveys indicate that GCP well construction would impact the desert tortoise or sensitive species, then measures to move an individual well site would be taken, provided that the scientific requirements of the GCP are not unacceptably compromised by the site relocation. DOE expects that both scientific and environmental requirements could be met by relocating wells.

Drilling returns of fluids and cuttings and fluids produced during pump tests would be continuously monitored for radiation levels. Samples would be taken hourly for tritium. Tritium generally would be the first radionuclide to be detected where contaminants have migrated from an underground nuclear test site. Therefore, hourly tritium monitoring would provide information to detect trends and is expected to give ample warning of an approaching contaminated plume. This early warning would allow crews to avoid personal exposure and allow implementation of provisions to control contaminated materials. All fluids 
produced during the operation of the wells would be discharged to lined sumps. If contamination is encountered, then pumping would be minimized and contaminated fluids would be transported from the lined sumps by truck or pipeline to steel tanks, centrally located to groups of drill sites. Fluids in the steel tanks would be evaporated and solids disposed of in accordance with all applicable environmental requirements, including established NTS procedures for radioactive waste. Although not expected, if hazardous waste is encountered, it would be disposed of off-site In accordance with all Resource Conservation and Recovery Act requirements. Mixed wastes (wastes containing both radioactive and hazardous constituents) would be managed at the NTS Area 5 waste management facility in accordance with all applicable requirements. All produced uncontaminated water would be discharged to nearby natural drainages in accordance with established procedures in a manner that would minimize erosion.

The proposed aquifer testing is expected to last approximately 24 to 72 hours per site with pumping rates ranging from $0.9 \mathrm{l} / \mathrm{sec}$ [15 gal/min] to $25 \mathrm{l} / \mathrm{sec}$ [ $400 \mathrm{gal} / \mathrm{min}$ ] and total water production of $82 \mathrm{~m}^{3}[21,600 \mathrm{gal}]$ to $7,650 \mathrm{~m}^{3}[2,000,000 \mathrm{gal}]$. Long-term llength of time to be determined when the initial results of the program are available) sampling at the well sites is anticipated, with samples being taken at intervals determined by the results of the initial drilling and sampling. Present estimates are that quarterly samples would be obtained for long-term sampling. 
Air quality impacts would be minimized by routine dust and emission controls during construction. Upon completion of the proposed action, disturbed areas would be mitigated through reclamation activities.

If preactivity surveys identify the presence of historic and/or archaeological resources at a proposed well site, measures would be taken to move the well site or conduct a data recovery program. A Programmatic Agreement (PA) among the DOE, the state of Nevada Historic Preservation officer (SHPO), and the Advisory Council on Historic Preservation (ACHP) covers the areas of Pahute and Rainier Mesas. DOE will take no action in the remaining areas of the NTS until they are governed by a PA. Currently, a PA is being negotiated which would cover the non-mesa areas. DOE has consulted with the SHPO regarding additional non-mesa drill sites. DOE will comply with the provisions of the final non-mesa PA to avoid significant adverse impacts to archaeological sites.

Consultations regarding Native American burial sites would be conducted and completed in accordance with Nevada Revised Statutes (NRS 383.170). 
In the unlikely event that sensitive plant populations are found at a needed GCP site, every effort would be made to avoid or minimize the impacts to individual plants or habitat.

\begin{abstract}
All mitigation measures identified in DOE/EA-0532 are integral elements of the proposed action and are committed aspects of this project for DOE. DOE considers those mitigation measures related to protecting sensitive biological, cultural and historic resolices as essential to render the impacts of the proposed action not significant. A MAP explaining how such mitigations will be planned and implemented has been completed. The MAP may be revised as more detailed and specific information becomes available.
\end{abstract}

ENVIRONMENTAL IMPACTS: The proposed action would not affect the following resources because they are not present on the NTS: Areas of Critical Environmental Concern regulated under the Federal Land Policy Management Act of 1977 (ELPMA); farmlands regulated under the Surface Mining Control and Reclamation Act of 1977; floodplains as specified by E.O. 11988; wetlands and riparian zones regulated under the wild and Scenic Rivers Act; and wilderness regulated under FLPMA and the Wilderness Act of 1964.

The GCP would result in minor local modification to site topography due to pad and sump preparation, access road 
construction and improvements, and development of borrow areas. Cunstruction activities associated with the proposed action are not expected to have any adverse effects on site topography or physiography.

Air emissions from construction and operational activities would include: dust from vehicular traffic and wind erosion of exposed surface areas (water trucks would be used to moisten exposed surface areas to reduce airborne particulates); and emission of pollutants $\left(\mathrm{CO}, \mathrm{SO}_{\mathbf{x}}\right.$, and $\mathrm{NO}_{\mathrm{x}}$ ) from construction vehicles, diesel engines used with drills, pumps, air compressors, generators, and other drilling and testing equipment. No release of toxic or hazardous materials is anticipated as a result of the proposed action because there is little chance that significant amounts of these materials occur naturally in the soil at the drill sites. There is, however, a possibility that radioactive materials exist at water table depths due to extensive underground nuclear testing. If radioactive materials are encountered they would be diverted to steel tanks so there would be virtually no chance of release to the surface environment.

Modelling results indicate that ambient air quality standards are unlikely to be exceeded. It is not anticipated that the GCP would have any adverse effect on geologic or mineral resources. 
There would be no adverse effect on regional hydrology or on the NTS water supply. Drawdown and aquifer impact would be minimal and transitory. To prevent interaquifer communication or contamination following well completion, producing zones would be isolated from each other through design and construction requirements. Uncontaminated water discharge from aquifer testing may lead to minor local erosion during the test period and would add water to the near-surface unsaturated zone.

The preparation of 100 well sites would include the removal of approximately 32 hectares (79 acres) of vegetation, with an additional 370 hectares (914 acres) of vegetation removed for access road construction and improvement. The four well sites analyzed in the EA were located away from vegetation considered unique or sensitive. DOE expects that, for the total number of wells that would be needed, the total disturbance for any vegetation type would be small in comparison to the overall land area coverage at the NTS. Therefore, these land disturbances are not expected to result in a significant adverse environmental impact. Loss of vegetation is expected to have only localized minor effects on wildlife.

Sensitive plant and animal species would be protected, to the extent practical, by moving any drilling sites that may conflict with them. All activities would be consistent with the requirements of the Endangered Species Act. Despite stringent 
measures to avoid impacts to the threatened desert tortoise, there remains a risk of injury or death to individual tortoises. DOE expects that such a risk would be minimal, and the continued existence of the desert tortoise would not be affected. Similarly, there would be a potential for incidental impact on individuals of sensitive species. Preactivity surveys and avoidance and minimization policies would preclude significant impacts. The four existing well sites are not located in the area of the desert tortoise habitat.

All activities would be consistent with applicable PAs between DOE, the Nevada SHPO, and the Advisory Council for Historic Preservation. Preactivity surveys, avoidance, and/or data recovery would ensure compliance with legally mandated historic preservation requirements.

Project activities would intermittently affect visual resources by interrupting the natural wide open expanses. However, extensive or significant effects on visual resources are not expected.

The GCP is not expected to have any adverse socioeconomic effects. The funds associated with the proposed action would add to the economic health of the region. Additional employees associated with this activity would not adversely affect housing, schools, or any other socioeconomic aspects of the region. 
Worker protection would be achieved through standard operating procedures for equipment, safety manuals, training, and use of required safety equipment. Noise levels are expected to be high during drilling, but hearing protection equipment, required for all personnel, would ensure worker protection. During drilling operations, there is a minimal potential for radiation exposure to drilling crews and GCP staff because monitoring would detect contamination before it could increase to harmful levels, and because areas of significant surface contamination would be avoided. Administrative controls would ensure that the extent of any exposure to radiation would be limited within DOE health standards.

Significant cumulative impacts on geologic, hydrologic and soil resources are not expected to result from the the GCP. Cumulative impacts on biological resources including vegetation, wildife, and sensitive species are anticipated to be minor. Cumulative impacts on air resources, cultural resources, visual resources, noise levels, and worker safety and health are expected to be minor. Cumulative socioeconomic impacts are expected to be minor.

ALTERNATIVES CONSIDERED: Under the no action alternative, no new characterization wells would be drilled, and thus no construction of drill pads, sumps, and access roads for those wells would be conducted. With no drilling of wells, a groundwater modeling 
program might be used. A modeling program, however, would not aciequately characterize the NTS groundwater because, due to spatial and temporal deficiencies in avallable hydrogeologic parameters, the model would not provide the level of information needed to comply with applicable laws and regulations which address groundwater issues.

Other alternatives considered were to use less intrusive geophysical. methods, drilling additional or fewer wells, and using different drilling techniques. Less intrusive techniques would not provide critical hydrologic data for porosity, permeability, transmissivity, pressure gradients, or groundwater chemistry, and would not meet DOE's need to adequately characterize the groundwater system. Similarly, fewer wells may not provide sufficient spatial and temporal data to adequately characterize groundwater parameters. More wells or different technologies may provide sufficient data to meet DOE's needs. Environmental impacts under alternatives involving more wells than the proposed action would in principle have proportionately greater impacts. However, because the impact analysis used conservative estimates, the EA concludes that alternatives involving up to 20 wells more or fewer than the proposed action would have substantially the same environmental consequences.

DETERMINATION: Based on the analysis in the EA, the proposed groundwater characterization program is not a major Federal 
action significantly affecting the quality of the human environment within the meaning of NEP1. Therefore, an environmental impact statement for the proposed action is not required.

Issued at washington, D.C. this 1992.

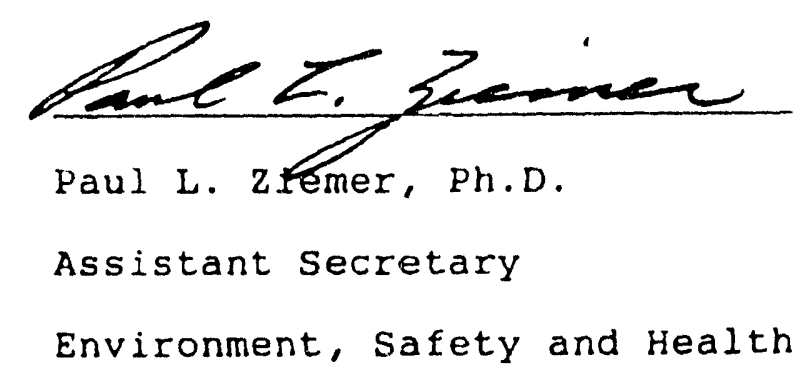




\title{
ENVIRONMENTAL ASSESSMENT FOR THE GROUNDWATER CHARACTERIZATION PROJECT, NEVADA TEST SITE, NYE COUNTY, NEVADA
}

\author{
U.S. Department of Energy \\ Nevada Operations Office \\ Environmental Restoration \& Waste Management Division \\ Las Vegas, Nevada 89193
}

DOE/EA-0532

AUGUST 1992

Rev. 1 


\section{CONTENTS}

LIST OF FIGURES $\quad$ v

LIST OF TABLES $\quad$ vi

ACRONYMS

1.0 INTRODUCTION 1-1

1.1 Proposed Action and Purpose of Proposed Action 1-1

1.2 Need for Proposed Action 1-1

1.3 Scope of Environmental Assessment 1 1-2

1.4 Background 1-5

1.4.1 History 1-5

1.4.2 Existing Operations and Site Conditions $1-11$

1.5 Land Use Policies and Plans for Affected Area 1-13

2.0 PROPOSED ACTION AND ALTERNATIVES 2-1

2.1 Proposed Action $2-1$

2.2 Alternative Actions $2-8$

2.2.1 No Action $2-8$

2.2.2 Other Alternatives $\quad 2-8$

3.0 AFFECTED ENVIRONMENT 3-1

3.1 Physiographic Setting 3-1

3.2 Climate and Meteorology 3-2

3.3 Air Quality 3-5

3.3.1 Ambient Air Quality Standards 3-5

3.3.2 Estimated Air Quality at GCP Well Sites 3-8

3.3.3 Visibility 3-8

3.3.4 Toxic/Hazardous and Radioactive Air Emissions 3-9

$\begin{array}{lr}3.4 \text { Geology and Minerals } & 3-10\end{array}$

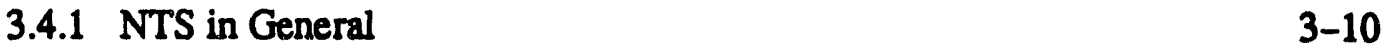

3.4.1.1 Geology 3-10

3.4.1.2 Minerals 3-12

3.4.2 Characterization Well Sites 3-13

3.4.2.1 Site ER-19-2 3-13

3.4.2.2 Site ER-EC-2 3-13

3.4.2.3 Site ER-12-1 3-14

3.4.2.4 Site ER-9-1 3-14 
3.5 Hydrology and Water Resources 3-14

3.5.1 NTS in General 3-14

3.5.1.1 Surface Water 3-14

3.5.1.2 Groundwater 3-15

3.5.1.3 Potential Groundwater Contamination 3-24

3.5.1.4 Water Supply 3-24

3.5.2 Characterization Well Sites 3-25

3.5.2.1 Site ER-19-2 3-25

3.5.2.2 Site ER-EC-2 3-25

3.5.2.3 Site ER-12-1 3-25

3.5.2.3 Site ER-9-1 3-28

3.6 Biological Resources 3-28

3.6.1 Vegetation 3-28

3.6.1.1 Characterization Well ER-19-2 3-29

3.6.1.2 Characterization Well ER-EC-2 3-29

3.6.1.3 Characterization Well ER-12-1 3-29

3.6.1.4 Characterization Well ER-9-1 3-29

3.6.2 Wildlife 3-29

3.6.3 Sensitive and Protected Species $\quad 3-30$

$\begin{array}{ll}\text { 3.6.3.1 Plants } & 3-30\end{array}$

3.6.3.1.1 Characterization Well ER-19-2 3-31

3.6.3.1.2 Characterization Well ER-EC-2 3-31

3.6.3.1.3 Characterization Well ER-12-1 3-31

3.6.3.1.4 Characterization Well ER-9-1 3-33

3.6.3.2 Wildlife 3-33

3.7. Historic and Cultural Resources 3-34

3.7.1 Previous Cultural Resource Sudies 3-35

3.7.1.1 Characterization Well ER-19-2 3-36

3.7.1.2 Characterization Well ER-EC-2 3-37

3.7.1.3 Characterization Well ER-12-1 3-37

3.7.1.4 Characterization Well ER-9-1 3-38

3.7.2 Reconnaissance Methods 3-38

3.7.3 Reconnaissance Results 3-39

3.7.3.1 Characterization Well ER-19-2 3-39

3.7.3.2 Characterization Well ER-EC-2 3-39

3.7.3.3 Characterization Well ER-12-1 3-40

3.7.3.4 Characterization Well ER-9-1 3-40

3.8 Visual Resources 3-41

3.9 Socioeconomics $3-41$ 
4.0 ENVIRONMENTAL CONSEQUENCES

4.1 Topography and Physiography $4-1$

4.2 Climate and Meteorology 4-3

4.3 Air Quality Impacts 4 4-3

4.3.1 Nature of Atmospheric Emissions 4-3

4.3.1.1 Construction Activities 4-3

4.3.1.2 Operational Activities 4-3

4.3.2 Assessment of the Air Quality Impact of Atmospheric Emissions 4-3

4.3.2.1 Method 4-3

4.3.2.2 Total Emissions $\quad$ 4-4

4.3.2.3 Short-Term Concentrations (Construction) 4-9

4.3.2.4 Annual Average Concentrations 4-11

4.3.2.5 Conclusions 4-11

4.4 Geology and Minerals $\quad$ 4-12

4.5 Hydrology and Water Resources 4-12

4.6 Biological Resources $\quad$ 4-14

$\begin{array}{lll}\text { 4.6.1 Vegetation } & \text { 4-14 }\end{array}$

\begin{tabular}{lr} 
4.6.2 Wildlife 4-14 \\
\hline
\end{tabular}

$\begin{array}{ll}\text { 4.6.3 Sensitive Species } & \text { 4-15 }\end{array}$

4.7 Historical and Cultural Resources 4-16

4.8 Visual Resources $\quad$ 4-17

4.9 Socioeconomics 4-17

4.10 Occupational Hazards, Noise and Worker Safety 4-17

4.11 Cumulative Impacts $\quad$ 4-18

5.0 REFERENCES 5-1

6.0 PREPARERS 6-1

7.0 OTHER AGENCIES AND ORGANIZATIONS CONSULTED 7-1

APPENDICES

A. Design Concepts and Construction of the Characterization Wells A-1

B. Sensitive Species Preactivity Survey Plan for GCP Well Sites B-1

C. Archaeological Preactivity Survey Plan for GCP Well Sites C-1

D. DOE/NV Radiation Exposure Standards $\quad$ D-1

E. Methods and Calculations for Air Quality Environmental Assessment E-1 


\section{LIST OF FIGURES}

1.1 Location of the 10 Potential Drilling Sites for the Groundwater

Characterization Project as of August 1991.

1.2 General Location Map of the Nevada Test Site.

1.3 Principal Features and Operating Areas of the Nevada Test Site.

1.4 Location of Underground Shaft Tests Conducted Beneath the Water Table on the Nevada Test Site.

1.5 Areas of Potential Groundwater Contamination on the Nevada Test Site.

2.1 Proposed Design of Drill Pad and Sump for the Groundwater Characterization Project.

3.1 Physiographic Entities of the Nevada Test Site.

3.2 Annual Wind Rose for Frenchman Flat. Wind Speeds are in Miles Per Hour.

3.3 Geologic Terrains and Mining Districts, Nevada Test Site.

3.4 Boundaries of Basins and Directions of Surface Drainage, Nevada Test Site, Mercury, Nevada.

3.5 Natural Surface Water at the Nevada Test Site, Mercury, Nevada.

3.6 Composite Potentiometric Contours of the Nevada Test Site.

3.7 Composite Potentiometric Surface for the Nevada Test Site.

3.8 Major Rock Types on the Nevada Test Site.

3.9 Generalized Groundwater Flow Beneath Frenchman Flat and Vicinity.

3.10 Water Supply System on the Nevada Test Site. 


\section{LIST OF TABLES}

1-1 Biogeophysical Attributes of 10 Potential GCP Sites, Including 4

Evaluated Sites.

1-2 Schedule for Projected Numbers of GCP Wells to be Drilled in Geographic Areas.

1-3 Probable Biogeophysical Attributes for any Specific Location Within Six Geographic Areas of NTS.

3-1 Physiographic Features and Elevations at NTS.

3-2 Humidity, Evaporation and Precipitation Conditions of the Frenchman Flat Area, Nevada Test Site.

3-3 Ambient Air Quality Standards (micrograms per cubic meter).

3-4 Hydrostratigraphic Classification of Principal Lithologic Units Encountered on the NTS.

3-5 Hydrogeologic Properties of Major Hydrostratigraphic Units at NTS.

3-6 Groundwater Use Summary For NTS, 1984-1988.

3-7 Water Chemistry for Representative NTS Water Supply Wells.

3-8 Plant Candidates to the Federal Threatened and Endangered List Occurring on the NTS.

4-1 Total Disturbed Area by the Projected 100 Wells According to Geographic Area.

4-2 TSP Emissions (tons) from Construction Activities.

4-3 Heavy Equipment Emissions (tons) During Construction Activities.

4-4 TSP Emissions (tons) from Operational Activities.

4-5 Total Emissions (tons) From Diesel-Fueled Drilling and Testing Equipment During Operational Phase.

4-6 Total Annual Post-Operations Particulate Emissions from Exposed Access Road and Sump Pit Areas.

4-7 Incremental Total Controlled Emissions for 100-Well Program.

4-8 Maximum Contributions to Short-Term Ambient Concentrations.

4-9 Estimated Drawdowns ( $(\mathrm{s})(\mathrm{m})$ for Two Radii in the Carbonate. Welded Tuff, and Alluvial Aquifers for Bounding Ranges of Transmissivity ( $T$ ) and Storage Coefficients (S).

4-10 Summary of Overall Impacts of the Groundwater Characterization Project. 


\section{ACRONYMS}

\begin{tabular}{ll} 
AAQS & Ambient Air Quality Standards \\
ac & Acres \\
ACEC & Area of Critical Environmental Concern \\
ACHP & Advisory Council on Historic Preservation \\
AQCR & Air Quality Control Region \\
ARC & Archaeological Research Center (UNLV) \\
BA & Biological Assessment \\
BLM & Bureau of Land Management \\
C1 & Candidate, Category 1 for listing as threatened or endangered \\
C2 & Candidate, Category 2 for listing as threatened or endangered \\
CERCLA & Comprehensive Environmental Response, Compensation and Liability Act \\
CFR & Code of Federal Regulations \\
DRI & Desert Research Institute \\
DOE & Department of Energy \\
DOE/NV & Department of Energy/Nevada Operations Office \\
DOE/TDB & Department of Energy/Technology Development Branch \\
EA & Environmental Assessment \\
EIS & Environmental Impact Statement \\
EPA & Environmental Protection Agency \\
ERC & Environmental Research Center (UNLV) \\
ESA & Endangered Species Act \\
FLPMA & Federal Land Policy and Management Act \\
FS & Feasibility Studies \\
ft & Feet \\
GCP & Groundwater Characterization Project \\
H\&N & Holmes \& Narver \\
ha & Hectares \\
HP & Horse Power \\
IMACS & Intermountain Antiquities Computer System \\
ISCST & Industrial Source Complex Short Term \\
LANL & Los Alamos National Laboratory \\
LGF & Liquified Gaseous Fuels \\
LRSP & Long Range Study Plan \\
m & Meters \\
MSL & Mean Sea Level \\
NACHP & National Advisory Council on Historic Preservation \\
\hline
\end{tabular}




$\begin{array}{ll}\text { NAFR } & \text { Nellis Air Force Range } \\ \text { NDEP } & \text { Nevada Division of Environmental Protection } \\ \text { NDHPA } & \text { Nevada Division of Historic Preservation and Archaeology } \\ \text { NDOW } & \text { Nevada Department of Wildlife } \\ \text { NEPA } & \text { National Environmental Policy Act } \\ \text { NHPA } & \text { National Historic Preservation Act } \\ \text { NNWSI } & \text { Nevada Nuclear Waste Storage Investigation } \\ \text { NPL } & \text { National Priorities List } \\ \text { NRC } & \text { National Response Center } \\ \text { NRS } & \text { Nevada Revised Statutes } \\ \text { NTS } & \text { Nevada Test Site } \\ \text { NTSO } & \text { Nevada Test Site Operations } \\ \text { NTU } & \text { Nephelometric Turbidity Unit } \\ \text { PA } & \text { Programmatic Agreement } \\ \text { PLO } & \text { Public Land Order } \\ \text { PMM } 10 & \text { Particulate Matter } \leq 10 \text { microns mean aerodynamic diameter } \\ \text { QSC } & \text { Quaternary Sciences Center (DRI) } \\ \text { RCRA } & \text { Resource Conservation and Recovery Act } \\ \text { REECo } & \text { Reynolds Electrical and Engineering Company } \\ \text { RI } & \text { Remedial Investigations } \\ \text { RSN } & \text { Raytheon Services of Nevada } \\ \text { RWMS } & \text { Radioactive Waste Management Site } \\ \text { SARA } & \text { Superfund Amendments and Reauthorization Act } \\ \text { SHPO } & \text { State Historic Preservation Officer } \\ \text { TSP } & \text { Total Suspended Particulates } \\ \text { TLV-TWA } & \text { Threshold Limit Value-Time Weighted Average } \\ \text { UNLV } & \text { University of Nevada, Las Vegas } \\ \text { USFWS } & \text { United States Fish and Wildlife Service } \\ \text { USGS } & \text { United States Geological Survey } \\ \text { WSMO } & \text { Weather Service Meteorological Observatory } \\ & \end{array}$




\subsection{INTRODUCTION}

\subsection{PROPOSED ACTION AND PURPOSE OF PROPOSED ACTION}

The proposed action is to construct roads and pads, and to drill and monitor approximately 100 deep wells for the purpose of characterizing the groundwater system at the Nevada Test Site (NTS). The data derived from the Groundwater Characterization Project (GCP) would be used to delineate the groundwater flow system on a local (intrabasin) and regional (interbasin) scale and determine transport parameters (i.e., rates, pathways, etc.). The resulting information would be used to quantify the NTS hydrologic regime and evaluate the effects of past activities at NTS, including underground nuclear weapons tests conducted at NTS since 1962, on groundwater. The GCP would focus upon areas of potential groundwater contamination. Most GCP wells would be located on the NTS, although some would be located immediately adjacent to the NTS on lands withdrawn from public use by the U.S. Air Force.

\subsection{NEED FOR PROPOSED ACTION}

Underground nuclear testing at NTS has resulted in residual radioactive materials in, and adjacent to, shot cavities, both beneath and above the water table. The GCP would provide key data the Department of Energy (DOE) needs to determine effects of past activities at NTS on groundwater and to assess the characteristics of groundwater for purposes of future remedial action. DOE determined in 1987 that all past, present, and future nuclear test sites would be treated as Comprehensive Environmental Response, Compensation and Liability Act (CERCLA) sites (Memorandum from Bruce (ireen, Weapors Design and Testing Division, June 6, 1987). In accordance with this decision, certain steps have or will be taken consistent with the CERCLA, as amended by the Superfund Amendments and Reauthorization Act (SARA). These steps include: 1) discovery or notification of a release of hazardous substance(s); 2) preliminary assessment and evaluation of the release site; 3) remedial investigation and feasibility study; 4) removal of threat, if any, to public health, welfare or the environment; and 5) remedial action.

The National Response Center (NRC) and Nevada Division of Environmental Protection (NDEP) have been notified of CERCLA release(s) at the NTS and a preliminary assessment of the site has been prepared (DOE, 1988a). Plans for remedial investigations and feasibility studies for the NTS are currently being prepared. Remedial investigations and feasibility study plans include a characterization of the NTS groundwater system. This course of action is proposed by the Environmental Restoration and Waste Management Division of DOE as a method to gather data to evaluate the extent of possible groundwater contamination resulting from underground nuclear testing and various remeciial strategies for containment or cleanup. 


\subsection{SCOPE OF ENVIRONMENTAL ASSESSMENT}

The overall GCP program will result in construction of 90 to 120 wells. Preliminary indications suggest that approximately 100 wells will be needed, thus the analysis in this EA is centered on 100 wells. As of August 1991, only 10 of the 100 potential GCP well sites had been identified. These initial 10 wells were sited based on a critical analysis of the conceptual models of groundwater flow on the NTS. The approximate locations of these 10 wells were chosen by DOE to satisfy two conditions: 1) acquire data in the areas identified to be important for understanding regional and local groundwater flow in and around underground test areas; and 2) optimize placement (in light of the current conceptual models) to act as up- or down-gradient monitoring wells. The exact locations for the wells were refined by the U.S. Geological Survey (USGS), national labs, and other DOE contractors to optimize hydrogeologic and geologic information. This EA addresses the effects of the GCP by evaluating 4 of the 10 drilling sites which were planned and located as of August 1991 (Figure 1.1) and extending the results and findings to the full complement of GCP wells. With the exception of desert tortoise habitat, these four sites are located in environmental conditions approximately representative of those expected to occur in the vicinity of all GCP wells.

The four sites were selected for evaluation in this EA to provide an analysis of the effects of well construction on various physical, biological, and other environmental features and conditions occurring on NTS. Roads constructed to two of these sites would be nearly the longest built to any GCP site; the other two are intermediate in length. There are many hydrogeological and biological attributes that define the broad biogeophysical environments of the NTS. These features, in turn, determine the presence of other features such as cultural resources and sensitive species. The four sites selected for the detailed analysis varied, to the extent possible, in terms of their overall geographic, biological, and physical environment, and most of the biogeophysical attributes found in the NTS are represented in the four sites (Table 1-1).

Construction at each site may result in localized effects on the hydrogeological and biological attributes of the site, from road grading, pad excavation, construction, and drilling activities on 7.7 ha $(18 \mathrm{ac})$. Significant adverse impacts on these resources are not anticipated given the limited nature of the proposed action. Preactivity surveys for biological and archaeological resources will ensure that important resources are identified and evaluated. Mitigation measures that are both consistent with executed agreements with the cognizant agencies and appropriate to the findings of the preactivity surveys will ensure that significant adverse actions are avoided.

The four Characterization Well sites selected for analysis are ER-19-2, ER-EC-2, ER-12-1, and ER-9-1. Characterization Well ER-19-2 is located at the extreme northeast corner of Area 19, beyond where Kawich Canyon opens into Kawich Valley. Characterization Well ER-EC-2 is west of NTS on the Nellis Air Force Range (NAFR) along the south rim of Pahute Mesa. Characterization Well ER-12-1 is located on the approach to the E Tunnel portal, about midway along the base 


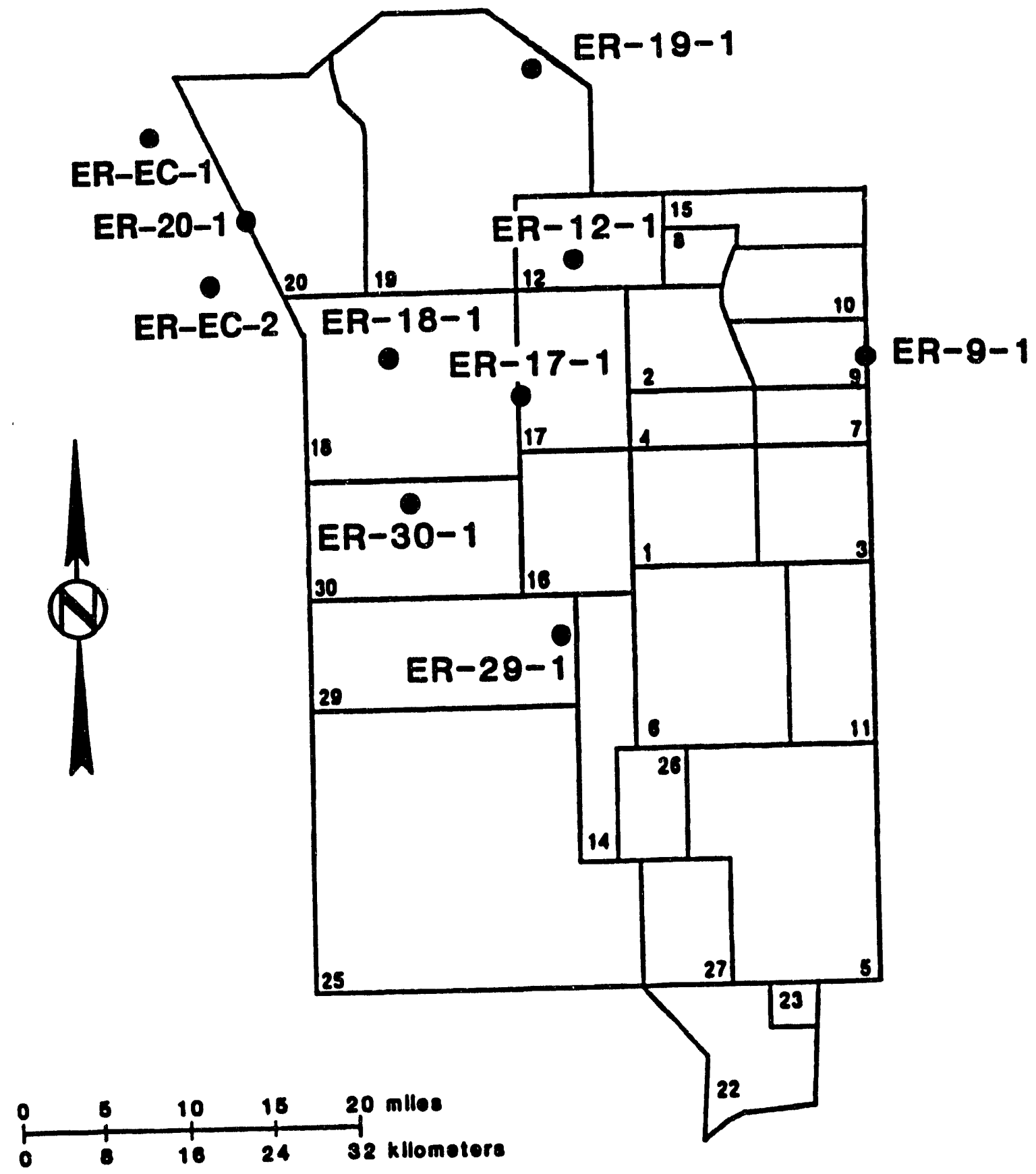

FIGURE 1.1 Location of the 10 Potential Drilling Sites for the Groundwater Characterization Project as of August 1991. 
TABLE 1-1 BIOGEOPHYSICAL ATTRIBUTES OF 10 POTENTIAL GCP SITES, INCLUDING 4 EVALUATED SITES.

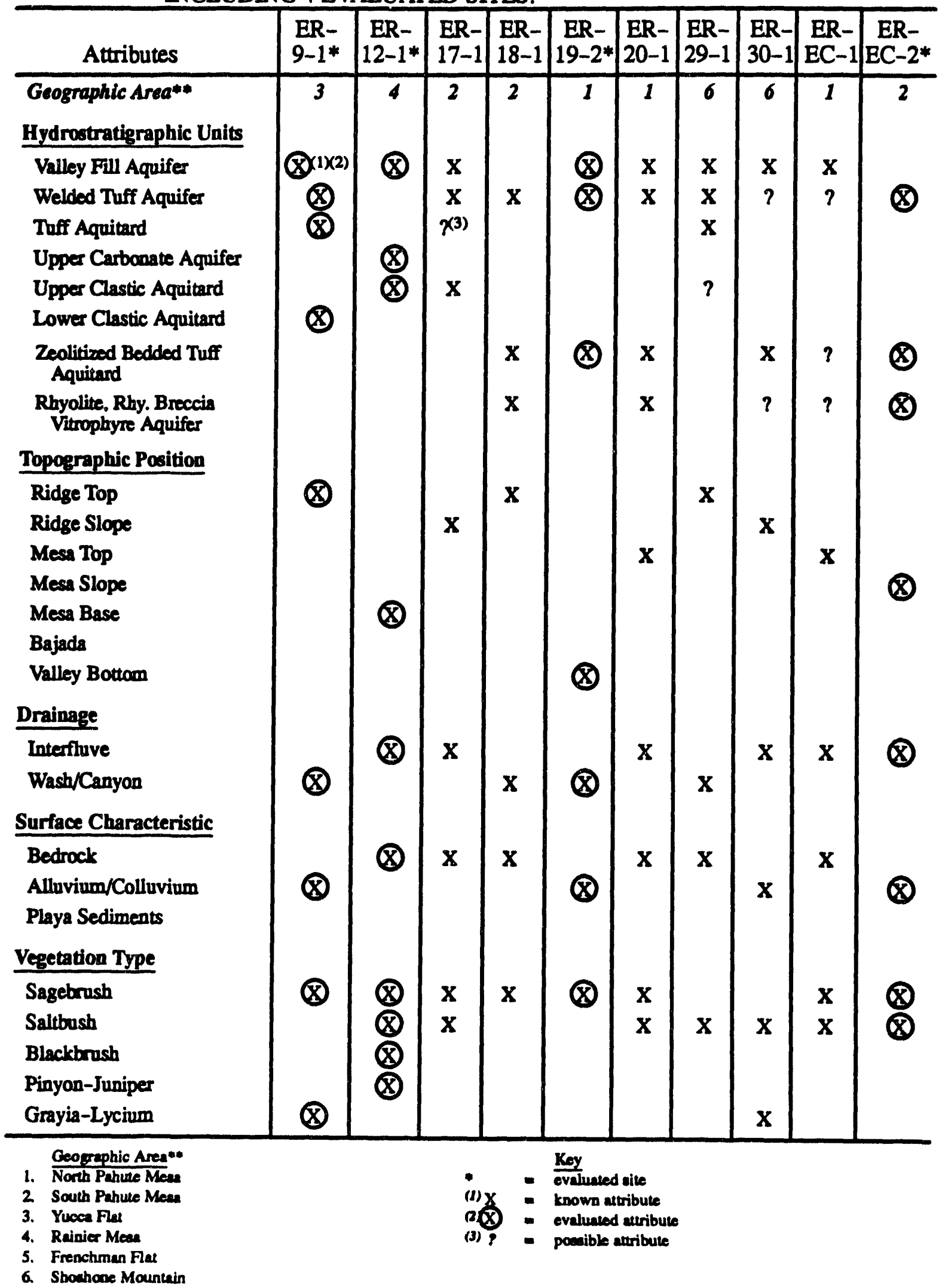


of the eastern side of Rainier Mesa in Area 12. Characterization Well ER-9-1 is located to the east of Yucca Flat in the Halfpint Range between the Slanted Buttes and Cockeyed Ridge in Area 9. The approximate number of GCP wells to be located in six geographic areas of the NTS has been tentatively identified as shown in Table 1-2. The specific sites within each area have not, however, been determined. The probability of occurrence of the biogeophysical attributes shown in Table 1-1 are listed for each area in Table 1-3. Whether or not any given attribute within an area would be encountered will be determined by the specific and individual location of wells when they are sited. Activities conducted at each site would vary only with respect to restraints on construction resulting from the geographic and physical site characteristics. Preference will be given to locating sites in previously disturbed areas if consistent with GCP scientific requirements. Consequently, some selected sites will be in previously disturbed areas. At any given site, effects from activities will be highly localized. Therefore, the analysis of 4 sites is logically extrapolated to include the complete set of 100 well sites, thus providing the overall assessment of project implementation.

The $20 \mathrm{GCP}$ wells planned for the Frenchman Flat area would be constructed within potential habitat of the Mojave Desert population of the desert tortoise (Gopherus agassizii), a threatened species (Federal Register 55:12178-12191). Section 7(a)(2) of the Endangered Species Act of 1973 as amended requires the DOE to consult with the U.S. Fish and Wildlife Service (USFWS) to insure that actions taken by DOE do not jeopardize the continued existence of the desert tortoise. $A$ Biological Assessment (BA) of the effects of all NTS activities (including the GCP) on the desert tortoise has been prepared by DOE and submitted to the USFWS, in accordance with Section 7 of the Endangered Species Act. The BA includes most ongoing and planned DOE activities on NTS during Fiscal Years (FY) 1991 through 1995, including the GCP. Due to schedule adjustments as the GCP matures, no wells are presently planned for construction in the Frenchman Flat area during this five-year period. The first two well sites on Frenchman Flat are planned for 1996. Wells constructed in desert tortoise habitat after 1995 would be covered in subsequent BAs.

This EA was prepared as part of an ongoing effort by DOE to assess the effects of NTS programs on the natural and economic environment. In 1977, an EIS was completed for the NTS and the programs ongoing at that time (ERDA, 1977). Subsequent to that time, all new initiatives on NTS have been subjected to environmental analysis to determine whether major environmental consequences would result. This EA is prepared as part of that ongoing environmental effort.

\subsection{BACKGROUND}

\subsubsection{History}

The NTS is a DOE facility occupying nearly $3,500 \mathrm{~km}^{2}\left(1,351 \mathrm{mi}^{2}\right)$ in southern Nevada. approximately $105 \mathrm{~km}(65 \mathrm{mi})$ northwest of the City of Las Vegas. The NTS is bordered to the 
TABLE 1-2 SCHEDULE FOR PROJECTED NUMBERS OF GCP WELLS TO BE DRILLED IN GEOGRAPHIC AREAS (drilling of one additional GCP well began under Categorized Exclusion in 1991).

\begin{tabular}{lcccccccccc}
\hline & 1992 & 1993 & 1994 & 1995 & 1996 & 1997 & 1998 & 1999 & 2000 \\
\hline North Pahute Mesa & 5 & 4 & 3 & 6 & 0 & 0 & 0 & 0 & 0 \\
\hline South Pahute Mesa & 0 & 1 & 3 & 3 & 0 & 0 & 0 & 0 & 0 \\
\hline Yucca Flat & 1 & 3 & 2 & 6 & 8 & 0 & 0 & 0 & 0 \\
\hline Rainier Mesa & 0 & 0 & 0 & 2 & 6 & 4 & 8 & 0 & 0 \\
\hline Frenchman Flat & 0 & 0 & 0 & 0 & 2 & 4 & 6 & 8 & 0 \\
\hline Shoshone Mountain & 0 & 0 & 0 & 0 & 0 & 0 & 3 & 8 & 3 \\
\hline TOTALS & 6 & 8 & 8 & 17 & 16 & 8 & 17 & 16 & 3 \\
\hline
\end{tabular}


TABLE 1-3 PROBABLE BIOGEOPHYSICAL ATTRIBUTES FOR ANY SPECIFIC LOCATION WITHIN SIX GEOGRAPHIC AREAS OF NTS.

\begin{tabular}{|c|c|c|c|c|c|c|}
\hline Attributes & $\begin{array}{c}\text { North } \\
\text { Pahute } \\
\text { Mesa }\end{array}$ & $\begin{array}{c}\text { South } \\
\text { Pahute } \\
\text { Mesa } \\
\end{array}$ & $\begin{array}{l}\text { Yucca } \\
\text { Flat } \\
\end{array}$ & $\begin{array}{c}\text { Rainier } \\
\text { Mesa }\end{array}$ & $\begin{array}{c}\text { Frenchman } \\
\text { Flat }\end{array}$ & $\begin{array}{l}\text { Shoshone } \\
\text { Mountain } \\
\end{array}$ \\
\hline Maximum Well Depth (m)* & 1.676 & 1.372 & 1.676 & 1,067 & 1.219 & 914 \\
\hline \multicolumn{7}{|l|}{$\begin{array}{l}\text { HYDROSTRATIGRAPHIC } \\
\text { UNITS }\end{array}$} \\
\hline Valley Fill Aquifer & 1 & 4 & 4 & 1 & 5 & 1 \\
\hline Welded Tuff Aquifer & 5 & 2 & 3 & 1 & 5 & 2 \\
\hline Tuff Aquitard & 5 & 2 & 3 & 2 & 3 & 3 \\
\hline Upper Carbonate Aquifer & 1 & 1 & 2 & 1 & 1 & 2 \\
\hline Upper Clastic Aquitard & 1 & 1 & 3 & 3 & 1 & 3 \\
\hline Lower Clastic Aquitard & 1 & 1 & 2 & 1 & 1 & 1 \\
\hline $\begin{array}{l}\text { Zoolitized Bedded Tuff } \\
\text { Aquitard }\end{array}$ & 3 & 2 & 3 & 2 & 2 & 2 \\
\hline $\begin{array}{l}\text { Rhyolite, Rhy. Breccia } \\
\text { Vitrophyre Aquifer }\end{array}$ & 3 & 2 & 1 & 1 & 1 & 1 \\
\hline TOPOGRAPHIC POSITION & & & & & & \\
\hline Ridge Top & 1 & 2 & 2 & 1 & 2 & 4 \\
\hline Ridge Slope & 1 & 2 & 2 & 2 & 2 & 4 \\
\hline Mesa Top & 5 & 3 & 1 & 5 & 1 & 2 \\
\hline Mesa Slope & 4 & 4 & 1 & 3 & 1 & 1 \\
\hline Mesa Base & 3 & 2 & 1 & 2 & 1 & 1 \\
\hline Baiada & 1 & 1 & 3 & 1 & 3 & 2 \\
\hline Valley Bottom & 1 & 1 & 5 & 1 & 5 & 1 \\
\hline DRAINAGE & & & & & & \\
\hline Interfluve & 4 & 3 & 4 & 4 & 4 & 3 \\
\hline Wash/Canyon & 2 & 3 & 2 & 2 & 2 & 3 \\
\hline $\begin{array}{l}\text { SURFACE CHARACTERISTIC } \\
\text { Bedrock }\end{array}$ & 5 & 4 & 2 & 5 & 2 & $A$ \\
\hline Alluvium/Colluvium & 2 & 2 & 5 & 1 & 5 & 2 \\
\hline Playa Sediments & 1 & 1 & 4 & 1 & 4 & 1 \\
\hline $\begin{array}{l}\text { VEGETATION TYPE } \\
\text { Sagebrush }\end{array}$ & 5 & 5 & 2 & 5 & 1 & 4 \\
\hline Saltbush & 1 & 3 & 4 & 2 & 4 & 3 \\
\hline Blackbrush & 3 & 5 & 3 & 4 & 2 & 3 \\
\hline Pinyon-Juniper & 4 & 2 & 1 & 4 & 1 & 3 \\
\hline Grayia-Lycium & 2 & 1 & 3 & 1 & 2 & 2 \\
\hline Creosote Bush & 1 & 1 & 2 & 1 & 4 & 2 \\
\hline
\end{tabular}

* multiply meters by 3.281 to obtain depth in feet

Probability of Occurrence at a Specific Location
1. highly unlikely; near $0 \%$
2. possible
3. maybe; near $50 \%$
4. very likely
5. virtually assured; near $100 \%$ 
north, west, and east by NAFR, a restricted access area (Figure 1.2). Activities at the NTS include a variety of nuclear and non-nuclear projects and experiments.

In the years immediately following World War II, an extensive review was conducted to identify a suitable area within the continental United States in which to conduct nuclear weapons testing. Criteria for the area included low population density, safety, favorable year-round weather conditions, security, available labor sources, reasonable accessibility including transportation routes, and favorable geology (ERDA, 1977). That review identified an area of approximately $1.750 \mathrm{~km}^{2}\left(676 \mathrm{mi}^{2}\right)$ within the Nellis Air Force Bombing and Gunnery Range (now NAFR) as being suitable. In 1952, land corresponding to what is now roughly the eastern half of the NTS was withdrawn from the NAFR under Public Land Order 805 (PLO 805) and made a part of the NTS. Additional land withdrawals were made in 1958, 1961, and 1964. Finally, under a Memorandum of Agreement with Department of Defense in 1967, the NTS achieved its current size and configuration with the acquisition of Pahute Mesa. The principal features and operating areas of the NTS are shown in Figure 1.3.

Since it was established in 1952, the primary mission of the NTS has been to serve as a proving ground for the testing and development of nuclear weapons. Through 1989 there have been in excess of 700 announced nuclear detonations on the NTS or adjacent controlled lands. All tests conducted at the NTS since July 1962 have been below ground and only one of those tests (Baneberry in December, 1970) resulted in significant unanticipated release of radioactive materials to the atmosphere that left NTS boundaries. Prior to 1963, a total of 105 tests were conducted above ground. This extensive testing of nuclear weapons has resulted in creation of significant amounts of radioactive materials at depth beneath the land surface and some residual radioactive material at land surface. Most nuclear weapons testing has been conducted in Areas 2,3,4,7,9,10,12, 19 and 20, although some tests were conducted in Area 5. In addition, testing occurred at the Nuclear Rocket Development Station located in Area 25 (refer to Figure 1.3).

Of the approximately 600 underground tests at the NTS through 1989, over 120 were conducted beneath the zone of saturation, or closely enough above that zone for the blast cavity to intersect the saturated zone.

The NTS has also been used for a number of secondary programs, although most have been related to nuclear energy or studies of the effects of radioactivity. Such programs have included: the Nuclear Rocket Development Station in Area 25; an experimental dairy farm in Area 15 to study radioactive dose models; experiments in Area 26 involving a nuclear reactor for a ramjet engine; and a "Bare Reactor Experiment" in Area 25, to study radiation effects on shielding, electronic components and biological tissues. More recently, a Liquified Gaseous Fuels (LGF) Spill Test Facility was established in the Frenchman Flat portion of Area 5. The purpose of the LGF facility is 


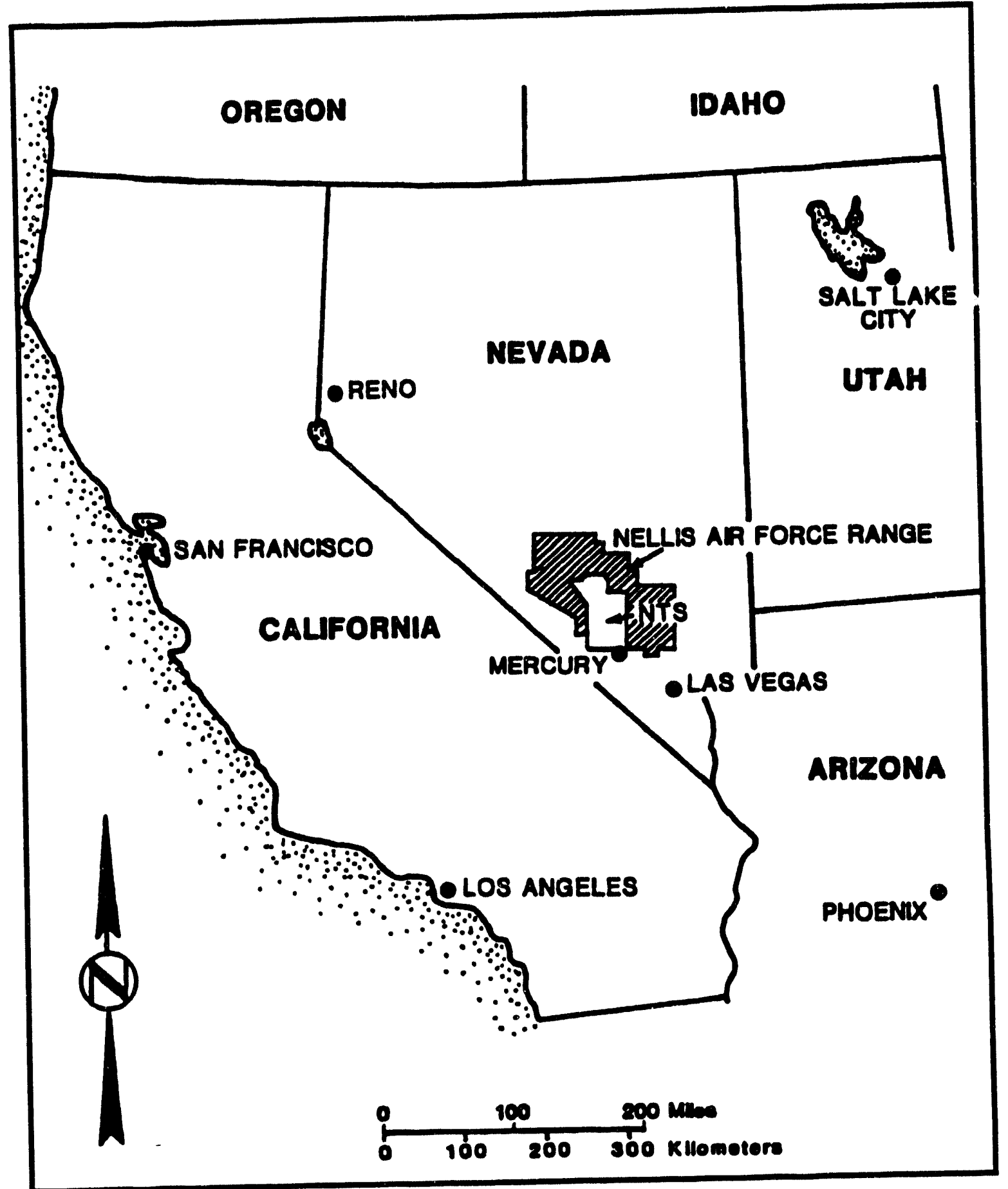

FIGURE 1.2 General Location Map of the Nevada Test Site. 


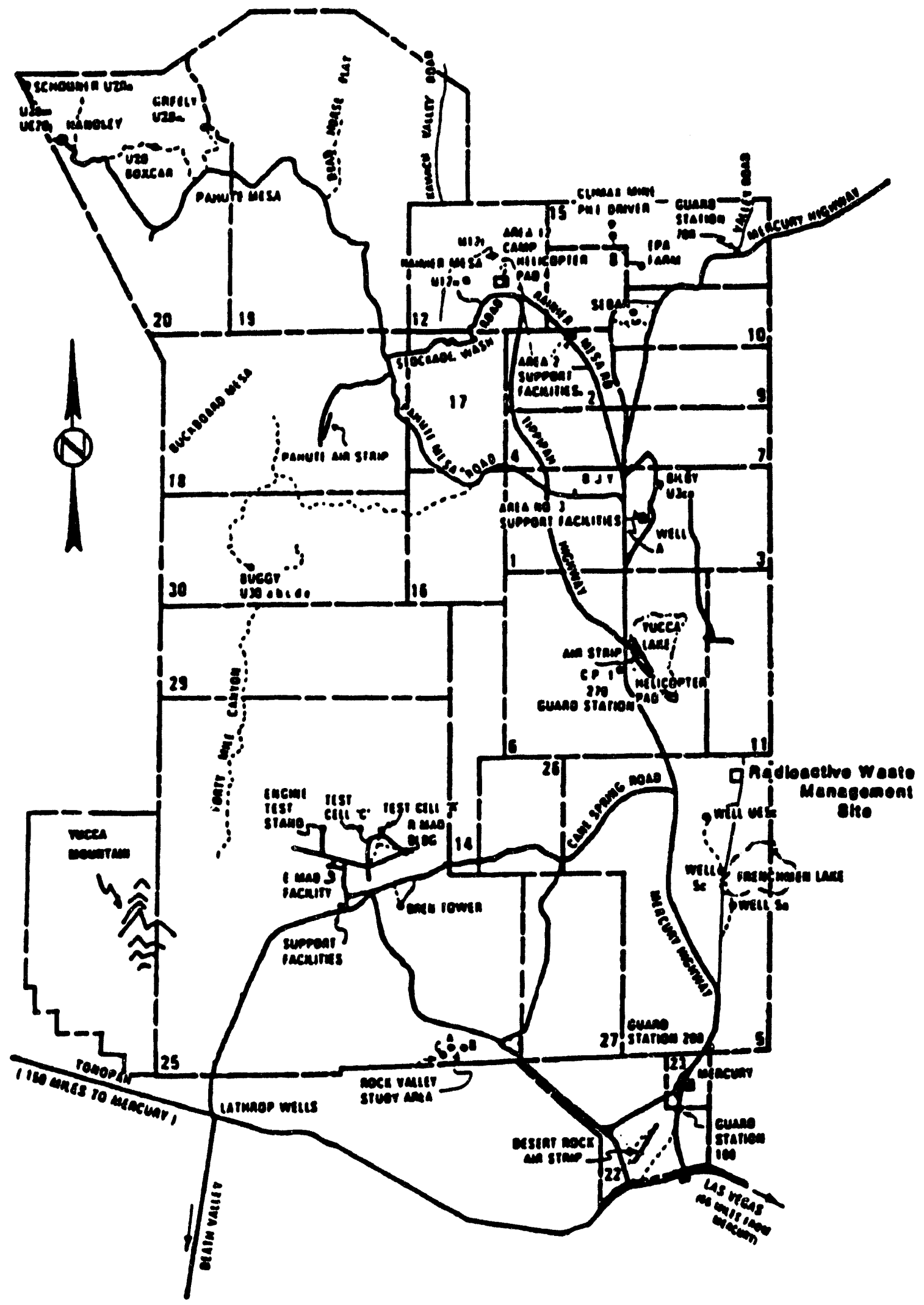

FIGURE 1.3 Principal Features and Operating Areas of the Nevada Test Site. 
to test the effects and behavior of accidental spills of liquified gaseous hazardous substances. Area 5 is also the location of the NTS' major Radioactive Waste Management Site (RWMS) for low-level and mixed waste disposal. A Hazardous Waste Accumulation Facility is located adjacent to the RWMS. Yucca Mountain, at the west edge of Area 25 , is currently being investigated as a potential location for disposal of high-level nuclear waste.

\subsubsection{Existing Operations and Site Conditions}

The current underground nuclear testing program uses only three areas of NTS: Yucca Flat (shaft tests in Areas 1, 2, 3, 4, 6, 7, 8, 9, 10,11, and 15); Rainier Mesa (tunnel tests in Area 12); and Pahute Mesa (shaft tests in Areas 19 and 20). The location of underground tests that have been conducted beneath the water table in these areas is shown in Figure 1.4. Also shown in this figure are four older tests conducted in Frenchman Flat (Area 5). Areas of potential groundwater contamination resulting from these and other tests and other activities are shown in Figure 1.5.

To support the nuclear testing program and other NTS activities, a substantial infrastructure has been developed, including housing, food service, water supply, wastewater treatment, offices and laboratories, roadways, and aircraft landing sites (fixed and rotary wing).

Permanent housing and food service facilities, together with offices, laboratories and equipment yards, are located at Mercury and at Area 12 Camp. Comparable facilities are located in Area 25 , but currently are largely unused. These facilities were built for the Nuclear Rocket Development Program. Permanent facilities that do not provide housing or food service are located at various sites around NTS; however, other than the RWMS, LGF Spill Test Facility and the Device Assembly Facility in Frenchman Flat, most are located in the vicinity of Yucca Flat and Jackass Flat. Temporary construction camps have been established on Pahute Mesa and elsewhere to support drilling activities, but do not include either housing or food service.

Water supplies for all NTS activities have been developed with wells in proximity to the major use areas. No springs or other surface water runoff are used for water supply purposes. There are only nine springs/seeps on all of NTS and they are low discharge. Water resource monitoring at NTS is conducted by DOE on a monthly basis. This program is basically "point of use" monitoring for radionuclides and ensures that water supplies, particularly domestic supplies, are safe for human consumption or other purposes. Only six wells are used for domestic purposes; the others supply construction water.

The road network on NTS is extensive and consists of primary paved roads; secondary paved roads; improved gravel roads; unimproved but maintained dirt roads; and unimproved, unmaintained dirt roads. The primary paved roads service the southern portion and eastern half of NTS and 


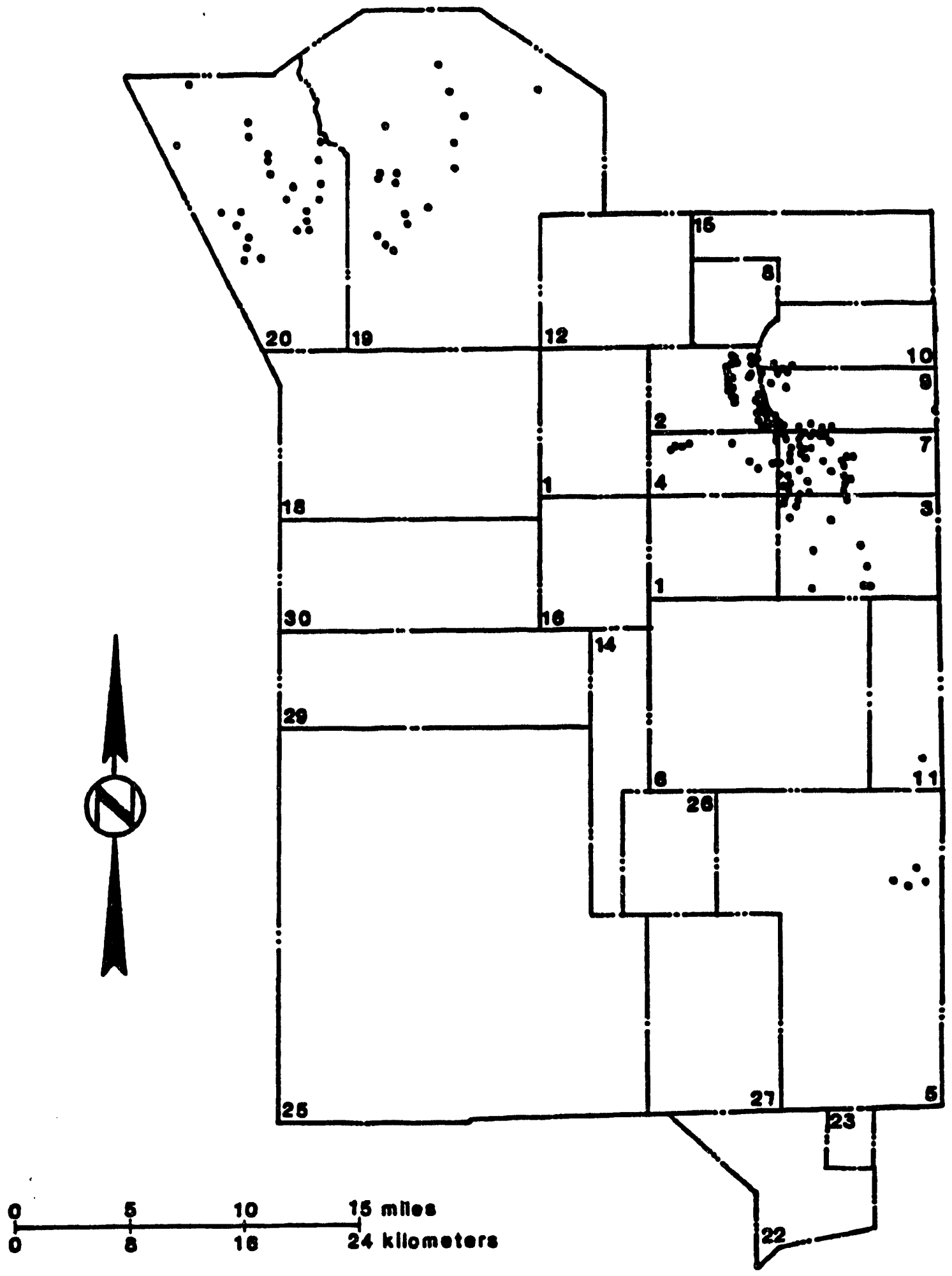

FIGURE 1.4 Location of Underground Shaft Tests Conducted Beneath the Water Table on the Nevada Test Site (DOE, 1988a). 


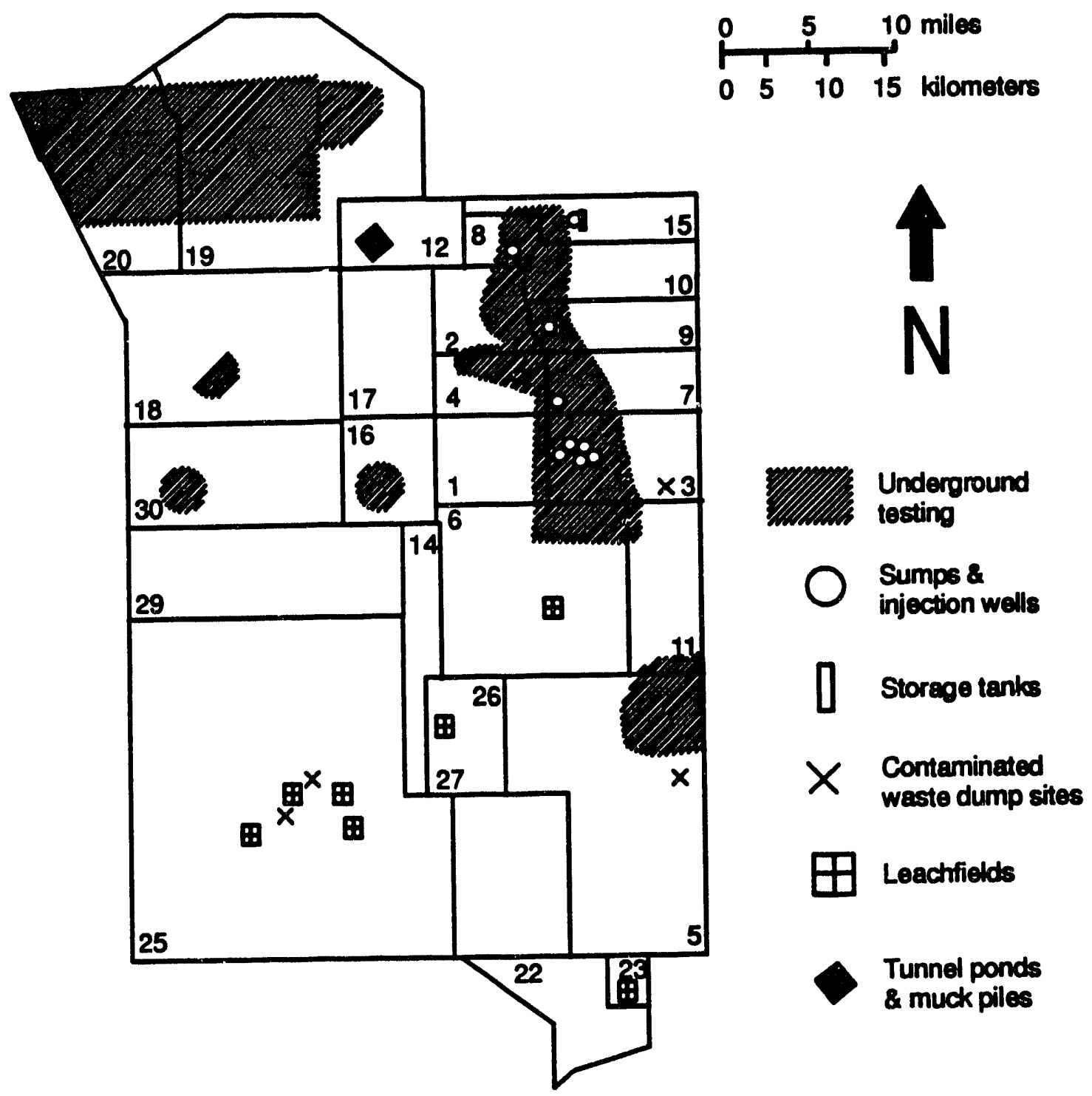

FIGURE 1.5 Areas of Potential Ground water Contamination on the Nevada Test Site (after Cullen and Russell, 1990).

extend into Pahute Mesa to the northwest. Improved and unimproved gravel roads provide access to most other areas of the NTS and to each specific nuclear test drill hole.

\subsection{LAND USE POLICIES AND PLANS FOR AFFECTED AREA}

The NTS is not open to public entry for purposes such as agriculture, mining, homestead, or recreation. Natural resources on NTS are managed under the Five-Party Cooperative Agreement 
among DOE, the Air Force, Nevada Department of Wildlife (NDOW), U.S. Bureau of Land Management (BLM), and the USFWS. Because of the nature of land use at the NTS over the last four decades, it is highly unlikely that the area will be returned to public use in the foreseeable future.

NAFR was withdrawn from public use originally in 1940 for training of World War II bomber pilots and crews. Those withdrawals were renewed by Congress in 1986 for a period of 15 years. Buildings, roads, and targets on the NAFR occur in limited locations, and thus most of the land is not actually used (i.e., there are no buildings, roads, or targets) by the AirForce, but simply provides a safety buffer between Air Force activities and adjacent public lands. No co-use of the lands for mining, grazing or other activities is currently allowed. The involved counties (Nye, Lincoln, and Clark) have no land use plans related to those lands. If, in the future, the NAFR is returned to public land status, the GCP wells would not interfere with mining, grazing or other public use of those lands. As with the NTS, NAFR natural resources are also managed under the Five-Party Agreement. 


\subsection{PROPOSED ACTION AND ALTERNATIVES}

\subsection{PROPOSED ACTION}

The proposed GCP would provide data needed for estimating groundwater transport rates and pathways in the regional groundwater flow systems located beneath the NTS. The proposed GCP would also provide groundwater quality data to determine the extent of groundwater contamination, if any. These data are needed to calculate the consequent risk of exposure to man and the environment. The GCP consists of approximately 100 characterization wells, proposed to be drilled, instrumented, and monitored on and adjacent to the NTS. The actual number of wells to be drilled during the program ( 90 to 120 ) would be determined by scientists associated with the project in consultation with regulatory agencies. This determination would be predicated upon incremental findings and interpretations as the GCP proceeds. Specific well sites would be selected to minimize adverse environmental effects. A range of 3 to 17 wells are anticipated to be drilled each year for the duration of the project. The depth of each well would typically be between 760 and 1,200 meters $(\mathrm{m})(2,500$ and 3,940 feet $[\mathrm{ft}])$. The maximum well depth would be $1,676 \mathrm{~m}(5,500 \mathrm{ft})$.

Driliing of the first GCP well began under Categorical Exclusion in FY91, primarily for purposes of technological evaluation. Drilling activities associated with the GCP would last approximately 5 to 10 years. Monitoring would be initiated at the completion of each well and continue through the life of the project. DOE/NV Environmental Restoration and Waste Management Division exercises direct control of the project. IT Corporation and Desert Research Institute (DRD), DOE contractors, in conjunction with a working group composed of representatives from USGS, Lawrence Livermore National Laboratory, and Los Alamos National Laboratory (LANL), would supply the scientific expertise and technical guidance for the program.

On a scientific basis, the preferred location for each well would be chosen as a result of a number of factors: hydrogeological information, gaps in current hydrologic knowledge, geologic uncertainty, research into transport phenomena, and legislated requirements for a groundwater monitoring system. As a result of the multifaceted characterization process, the wells would be placed in almost all broad environmental types on the NTS. Once scientific requirements are known, environmental factors would be considered to finally locate the wells. Biological and cultural resource preactivity surveys would be conducted prior to any surface-disturbing activity. Plans for these surveys are presented in Appendices B and C. It is not anticipated that either scientific or environmental constraints would be so limited as to preclude effective compromise locations which achieve both scientific and environmental requirements.

NVO54XC.1-30 provides guidance for protection of sensitive species under the Federal Endangered Species Act of 1973, as amended. This is to ensure that actions do not jeopardize the 
continued existence of endangered or threatened plants or animals, or result in the destruction or adverse modifications of critical habitat of any such species. In furtherance of this policy, biological preactivity surveys would be conducted on all proposed surface-disturbance sites except when previous disturbance has precluded all possibility of finding significant species. Even in such cases, an evaluation would be made concerning the possibility of pioneering species having established themselves in disturbed areas.

Because desert tortoises are found throughout the southern one-third of the NTS at a low to a very low abundance, a Biological Assessment (BA) of "The Effects of Activities of the U.S. Department of Energy Nevada Field Office, Nevada on The Threatened Desert Tortoise, July 1991 " has been prepared by DOE and submitted to the USFWS for formal Section 7 consultation. This BA addresses most ongoing and planned activities that will occur on the NTS through FY95, including the GCP, that may impact desert tortoises. This consultation is required because of the listing of the tortoise as a threatened species under the federal Endangered Species Act (ESA). A Biological Opinion (BO) containing a "no jeopardy" determination was obtained from the USFWS dated May 20, 1992.

The terms and conditions of this BO follow in condensed form ${ }^{1}$ as they would apply to the GCP.

All NTS workers shall complete a tortoise education program within 30 days of reporting to work. All personnel who conduct preactivity surveys or who will be on-site during preconstruction, construction, or maintenance activities related to projects identified in the BO shall fully understand the terms and conditions.

All vehicles shall be restricted to existing paved, graded, or utility access roads. Speeds shall be within posted limits or not to exceed $24 \mathrm{kph}$ (15 mph) within project boundaries.

Any tortoise within harm's way on a road shall be moved from the road in the direction that it is going. Before moving any vehicles or equipment, search the ground underneath to ensure that no tortoises are underneath.

No off-road vehicle driving in non-emergency situations is permitted unless authorized by DOE. Authorized use shall be so conducted as to minimize habitat destruction and the take of tortoises. Planned routes shall be surveyed for tortoises immediately prior to use. All tortoises and burrows shall be avoided. Shrubs shall be avoided as much as possible. Avoid grading of short-term project-related

The full text of the terms and conditions should be consulted for mitigation during field activities. Donot rely on this candensed version. 
roads. If damage is unavoidable, vegetation should be crushed rather than bladed. Processing of road surface materials for maintenance shall be done in previously disturbed areas only.

Flag or mark all project areas conspicuously and confine habitat disturbance thereto. Store all equipment and materials within project boundaries or in previously disturbed areas.

Complete $100 \%$ coverage surveys no more than 1 working day prior to any surface-disturbing activity. Flag burrows for avoidance or, if unavoidable, remove tortoises and eggs and crush the burrows. Use only qualified biologists to handle tortoises. Qualified biologist(s) shall be on-site whenever heavy equipment is being operated.

Release tortoises which must be moved from hazardous areas in safe areas $91 \mathrm{~m}$ to $305 \mathrm{~m}$ ( $300 \mathrm{ft}$ to $1000 \mathrm{ft}$ ) away.

Stop construction or maintenance activities if a tortoise is found in a project area following initial removal until it has moved from harm's way or until a biologist has removed it.

Trenches or excavations shall be inspected for entrapped tortoises and those with side slopes exceeding $0.3 \mathrm{~m}$ rise in $0.9 \mathrm{~m}$ length ( $1 \mathrm{ft}$ rise in $3 \mathrm{ft}$ ) shall be backfilled, covered, or tortoise-proof fenced prior to being left unattended. Such fences shall be monitored at least quarterly and maintained until the excavation has been backfilled.

Inspect open-ended pipes stored in tortoise habitat before moving to ensure that no tortoises are inside. Cap open-ended pipe segments during construction to bar tortoises.

Litter control shall be implemented during construction and maintenance activities so that ravens aren't encouraged.

Mitigation fees must be paid to the Habitat Conservation Fund to compensate for habitat loss at a rate of $\$ 324$ acre.

If preactivity surveys indicate that construction of any access road or well in the GCP would impact the desert tortoise, measures would be taken to avoid impacts by moving the location of the road or well site, provided that the scientific requirements of the GCP can still be achieved.

Due to schedule refinements since completion of the BA, no wells are expected to be drilled within tortoise range until 1996. Because of this, it is likely a new BO covering the activities subse- 
quent to FY95 would apply. For proposals outside the time frame or geographic scope covered by the present BO, no work that would risk a "take" or which would damage habitat would occur in tortoise habitat prior to completion of renewed consultation with the USFWS. Any project activities subject to the present or future BOs would be in strict compliance with the agreement reached during the consultation process. This would ensure that no jeopardy to the contimued existence of the species would result from this or other NTS programs discussed in the consultations.

Other sensitive animal or plant species occurring in the vicinity of GCP sites would be identified during preactivity surveys and efforts would be made to mitigate effects on those species to the extent possible.

NV054XD.1-29 provides guidance for compliance with the federal National Historic Preservation Act (NHPA) to ensure preservation of historic and archaeological resources of national significance. Activities on Pahute and Rainier Mesas have been covered by a Programmatic Agreement (PA) among the DOE, the Nevada State Historic Preservation Officer (SHPO), and the National Advisory Council on Historic Preservation (NACHP). The development of a Long Range Study Plan (LRSP) was agreed to in the PA. The resulting LRSP identified sample units within which data recovery is required. When GCP surface-disturbing activities are proposed in sample units, data recovery would be completed as required. Surveys outside of sample units would be conducted for historic sites. These surveys are required under the terms of the PA whenever an activity may affect a mesa site.

DOE has consulted with the SHPO regarding individual drill sites proposed outside of the mesa areas. With the exception of the Yucca Mountain Project for which a PA has been consummated between the Project Office and the NACHP, a PA now in progress addresses the treatment of cultural resources not on the two mesas for the remaining NTS programs. For off-NTS locations, coordination would include the appropriate land managing agency and the SHPO. On these offNTS locations, preactivity surveys would identify the nature and the extent of cultural resources present. DOE would avoid damage to any significant archaeological sites. This would be accomplished by relocation or redesign of roads or pads, by fencing, or other control measures. If this is impossible, then a data recovery plan would be developed and coordinated with the SHPO and the NACHP. Appropriate site-specific mitigation measures would be implemented.

Native American consultations regarding burial sites would be completed in accordance with Nevada Revised Statutes (NRS 383.160). Consultation with Native Americans is presently underway in accordance with the American Indian Religious Freedom Act. The terms of agreements reached through this process would be adhered to by the GCP.

As with the desert tortoise situation, no activities which would risk damage to cultural resources would take place in areas not covered by completed consultations or approved PAs. 
These activities and those in the areas covered by the draft PA would be in strict compliance with the agreed upon requirements.

A large variety of activities would be conducted in conjunction with each well site. Basically, these activities can be broken down into several categories. In addition to previously discussed archaeological and environmental preactivity surveys of pad and road sites, there would be construction of roads, drill pad, sump pit and burrow areas; drilling in the unsaturated zone; dry geophysical logging; drilling in the saturated zone; wet geophysical logging; hydrologic testing (including trace injector surveys); and well completion. Where feasible, considering factors such as soils, topography and aspect, reclamation will be applied to those portions of project areas not needed for long-term monitoring. These actions would include soil salvage, recontouring, ripping, seeding or other revegetation as appropriate. Erosion control will be an integral part of the project. The detailed well construction activities to be conducted at a typical well are presented in Appen$\operatorname{dix}$ A.

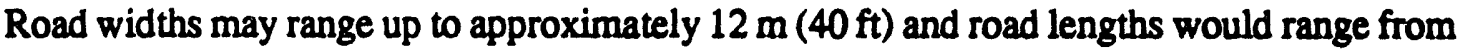
less than $1 \mathrm{~km}$ to over $10 \mathrm{~km}(0.6 \mathrm{mi}$ to over $6 \mathrm{mi})$ and average an estimated $6 \mathrm{~km}$ (3.7 mi). Drill pads and sumps would be constructed approximately as shown in Figure 2.1. Pads would measure approximately $61 \mathrm{~m} \times 61 \mathrm{~m}(200 \mathrm{ft} \times 200 \mathrm{ft})$ and are intended only to provide a stable, level working area for the drill rig and associated equipment. At some sites, their construction would entail cut and fill and at others, selected borrow material would be needed to build up the platform. The drilling fluid sum $_{2} \because$, would extend approximately $12 \mathrm{~m}$ (40 ft) into the drill pads toward the drill site. Where possible, the sumps would be excavated, but otherwise they would be a composite of excavation and built up sidewalls. All drilling fluid sumps would be lined with membrane to minimize infiltration losses of fluids.

Personnel exposure is possible due to proximity to contaminated materials, by inhalation, or ingestion, or by topical contact. Potential exposure or release pathways may be created by resuspension of contaminated surface soils during pad construction and through produced subsurface materials during drilling, testing, and operation of the wells. To obviate the risk of personnel exposure or risk of environmental release of contaminated materials, appropriate procedures would be followed. All well sites would be checked for radiation levels prior to commencement of earthwork at the location. No wells would be located in areas having radiation in excess of ten times background level. At or below this level, the risk of adverse effect with environmental release or personnel exposure would be minimal. It is not anticipated that wells would be necessary in areas of high surface contamination. However, if that should be necessary to obtain required data, the area would be cleaned to acceptable standards using standard NTS personnel protection procedures for clearance of radiation contaminated areas. 


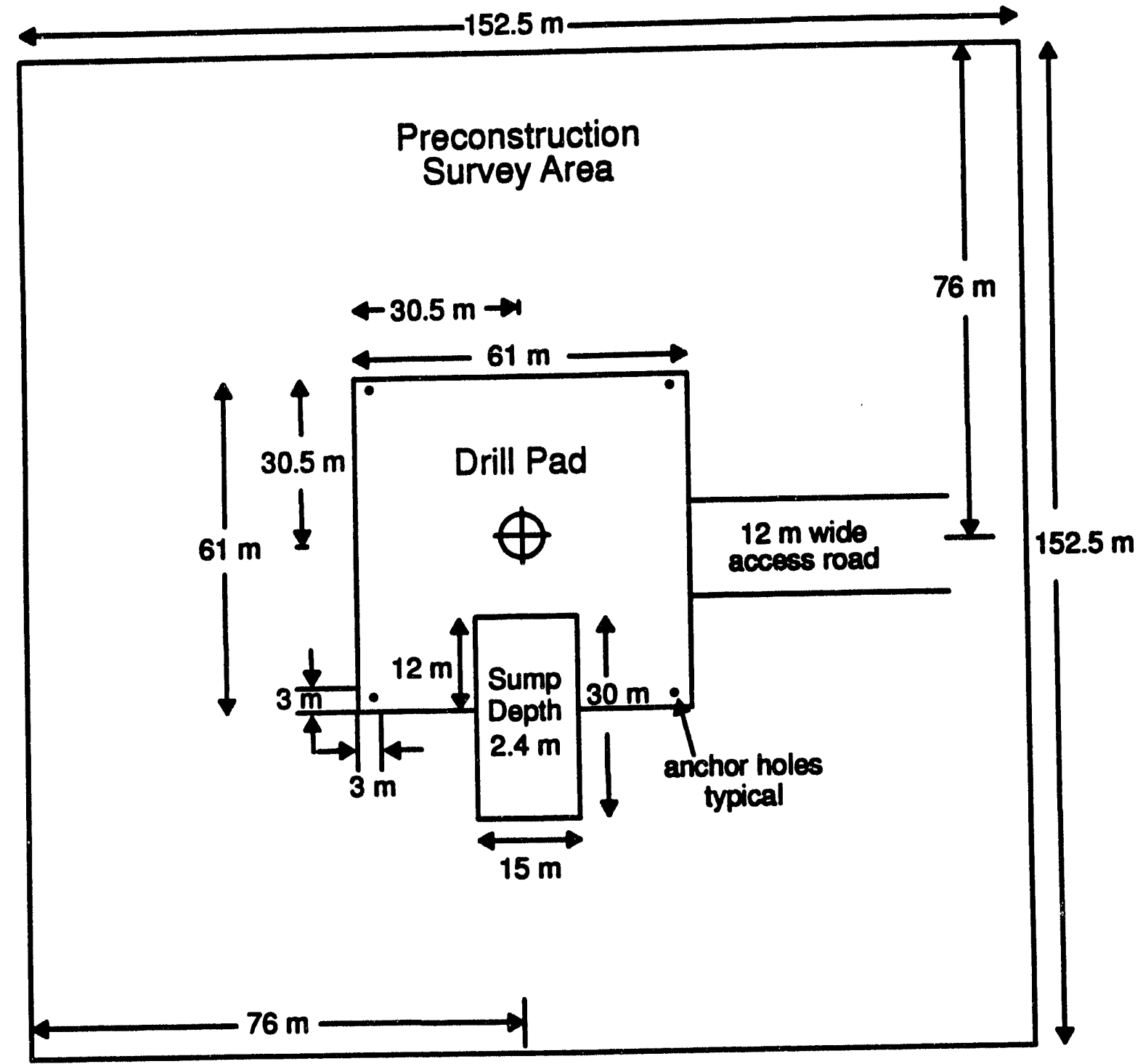

FIGURE 2.1 Proposed Design of Drill Pad and Sump for the Groundwater Characterization Project. 
For protection during drilling and pump testing, cuttings, muds, and produced fluids would be continuously monitored by an alarmed system for radioactivity in excess of DOE radiation protection standards (DOE 5480.11) (see Appendix D or other applicable standards). If present, radioactive or hazardous material contamination is expected to appear slowly, and to be preceded by tritium because of its mobility. Thus, the appearance of upward tritium trends would trigger increased monitoring frequency for other hazardous materials as well.

Samples would be taken hourly for tritium. If trends develop which indicate rising tritium levels are approaching the established limits, then sampling would be done at frequent intervals until upper limits are met. Immediately upon detection, contaminated materials would be shunted to holding tanks. It is not anticipated that any substances would be encountered in the initial wells which would result in classification of the water as a hazardous or mixed waste. However, should that occur, water would not be discharged outside of the lined sumps or tanks.

Limited pumping of contaminated wells may be necessary for the purpose of providing adequate data on the nature and extent of contamination. Operations would then cease until procedures have been completed, approved, ari implemented for handling and treating these liquids. Procedures are being developed to handle contaminated water found during the GCP project. Once implemented, operations at contaminated wells would resume and follow legal requirements and the approved procedures and treatment methods.

As the GCP progresses, the initial data would be examined in an effort to characterize the rates and directions of flow within the hydrogeological system in effort to determine possible sources of contamination. Based on this information, it would be necessary to drill closer to test shot areas in order to more precisely define the behavior of any contaminated groundwater plumes. This process of narrowing down sources of contamination would most likely occur towards the later portion of the program, e.8., FY96 or FY97. If contaminated water is encountered, whether in the initial or later GCP stages, it would be transported by truck to storage tanks recently approved by EPA for RCRA hazardous waste collection. These tanks would be open-topped, double walled, and equipped with leakage collection systems. Liquids would be treated by evaporation in these tanks in accordance with procedures now under development. It is anticipated that up to 10 wells could yield contaminated water requiring tank storage and treatment. Several sets of tanks would be erected in centrally located areas of about 1 to $2 \mathrm{ha} \mathrm{(} 2$ to $3 \mathrm{ac}$ ) in size. Sludge resulting from the evaporated water would be handled according to type. Radioactive fluids and materials would be disposed of in accordance with established procedures. While not expected, hazardous waste could be encountered. The sludge would be transported to the Area 5 RWMS facility for handling and storage, and would be disposed of off-NTS at a RCRA-licensed facility as with other NTS hazardous waste. Mixed wastes would be managed at the Area 5 waste management facility in accordance 
with approved procedures. If the water is determined to be non-RCRA waste, it would be handled in accordance with applicable standards.

After well completion, and prior to aquifer testing, water samples would be collected and analyzed for chemical constituent concentrations. Parameters analyzed for would include certain Nevada primary and secondary drinking water standards. Aquifer testing is anticipated to range from 24 to 72 hours. Pumping rates would range from $0.9 \mathrm{l} / \mathrm{sec}$ (15 gal/min) to $25 \mathrm{l} / \mathrm{sec}$ (400 gall $\mathrm{min})$. Total water produced would range from $82 \mathrm{~m}^{3}(21,600 \mathrm{gal})$ to $7,700 \mathrm{~m}^{3}(2,033,875 \mathrm{gal})$ and would be discharged to nearby natural drainages in a manner which minimizes erosion. As discussed previously, contaminated water would be transported to holding tanks. Pump testing of contaminated wells would be minimized.

Local erosion during pump tests would be addressed on a case-by-case basis through construction of rip-rapped discharge basins or laying of plastic sheeting. Discharge would not be allowed to free-fall from the discharge pipe or to form new channels, thereby creating erosion problems.

Non-pumping hydraulic testing will also be performed on GCP wills, including slug and injection tests. As a matter of comity, any water introduced into a well bore for testing purposes is expected to meet drinking water standards. If that is not possible because of logistical considerations, DOE will consult with the Nevada Division of Environmental Protection (NDEP).

Long-term monitoring would be performed at these wells. Samples would be taken at intervals which would be determined by the results of the initial drilling and sampling. Present estimates are that quarterly samples would be obtained. Final sampling methodology is still being determined, but basically would consist of setting up equipment over the well bore, lowering sampling equipment, collecting samples, and locking the well again. Water pumped during sampling would consist of a few liters per interval sampled.

The length of time these wells would remain in use would not be determined until the results of the program are available. If it is determined that they would be used as monitoring wells in support of CERCLA/RCRA remediation, then they would likely remain in use for decades.

With respect to the completed wells, a security system and plan would be developed to prevent access by unauthorized personnel who might purposely or accidentally contaminate the wells and aquifers. This plan would include an appropriate well head cover with locking device.

Well heads would be established in a manner to prevent entry of surface waters in order to protect the integrity of the aquifers as well as the quality of the data obtained from them. When no longer needed, sealing and permanent closure of wells to prevent interaquifer communication or surface contamination of aquifers is not expected to present unusual problems. This would be true even if the lands were returned to public use. 


\subsection{ALTERNATIVE ACTIONS}

\subsubsection{No Action}

Under the no-action alternative, no new characterization wells would be drilled, and thus there would be no construction of drill pads, sumps, and access roads for those wells. The no-action alternative might result in a program to model the groundwater flow system through the use of existing data. A modeling program would not adequately present environmental impacts to groundwater because no new information would be collected. The existing data are significantly deficient in terms of the spatial and temporal distribution of hydrogeologic parameters needed to develop an adequate model. The model developed thus would not provide the level of information needed for DOE/NV to comply with the provisions of CERCLA, SARA, Resource Conservation and Recovery Act (RCRA), and other authorities which address groundwater resources.

\subsubsection{Other Alternatives}

Alternatives to the proposed action (drilling of approximately 100 wells) include a range of strategies for program implementation involving fewer wells than the proposed action. For example, DOE considered drilling fewer wells and also employing less intrusive surface geophysical techniques (seismic and electrical). However, these non-intrusive techniques are incapable of providing hydrogeologic data needed (porosity, permeability, transmissivity, fluid energy gradients), or of providing data on formation water quality. Groundwater characterization data collection programs involving fewer wells would have proportionately less impacts than the proposed action, but they may not provide the spatial and temporal resolution needed to adequately characterize groundwater transport.

Alternatives involving more wells or different drilling technologies may provide the information required to comply with CERCLA and other environmental requirements. The proposed alternative for the GCP includes a reasonable strategy for drilling and associated activities over a 5 to 10-year period that would efficiently accomplish DOE/NV objectives. Impacts under alternatives involving more wells than the proposed alternative would in fact have proportionately greater impacts. However, because impact analysis uses conservative estimates, the analysis concluded that alternatives involving up to 20 wells more or fewer than proposed would have substantially the same environmental consequences. 


\subsection{AFFECTED ENVIRONMENT}

This section describes the environment for the areas to be affected by the alternatives under consideration. The proposed action would not affect the following resources since they are not present on the NTS: Areas of Critical Environmental Concern (ACECs) regulated under the Federal Land Policy Management Act of 1976 (FLPMA); farm lands regulated under the Surface Mining Control and Reclamation Act of 1977; floodplains as specified in EO 11988; wetlands and riparian zones regulated under the Wild and Scenic Rivers Act; and wilderness regulated under FLPMA and the Wilderness Act of 1964.

\subsection{PHYSIOGRAPHIC SETTING}

The NTS is located in the Great Basin portion of the Basin and Range Physiographic Province. The Province is characterized by a series of north-south trending mountain ranges separated by broad alluvial valleys. The Great Basin portion is characterized by its lack of external surface water drainage. Many of the valleys within the Great Basin are topographically closed and contain playas at the lower elevations. These playas are periodically flooded by precipitation and runoff from the surrounding mountains, but normally remain dry over a significant portion of most years. Playa elevations and basin floors increase in elevation from south to north across NTS as shown in Table 3-1 and Figure 3.1. This elevation change is accompanied by the northern boundary of the Mojave Desert and the southern boundary of the Great Basin Desert through a broadly defined transition zone. Bases of the mountains are situated at approximately 1,000 to $1,220 \mathrm{~m}(3,280$ to 4,000 $\mathrm{ft}$ ) mean sea level (MSL) elevation in the southem NTS, 1.220 to $1,520 \mathrm{~m}(4,000$ to 4,990 ft) in the central part, and 1,520 to $1,830 \mathrm{~m}(4,990$ to $6,005 \mathrm{ft})$ in the northern part. The highest elevation on NTS is $2,354 \mathrm{~m}(7,723 \mathrm{ft})$ at the southern end of the Belted Range.

Most of the GCP wells (greater than approximately 60 percent) would be located adjacent to areas where underground nuclear testing has been conducted. These areas are: Yucca Flat, Frenchman Flat, Pahute Mesa, and Rainier Mesa. Yucca and Frenchman Flat are topographically closed basins in the eastern and southem portion of NTS, with no outlets for surface runoff or gravitational flow of air at night. Each area is characterized by a large playa at the lowest elevation. Pahute and Rainier Mesa, located in the northwest portion of NTS, are the two highest mesas on the site. Of the four sample well sites, ER-EC-2 is located on the west end of Pahute Mesa, ER-9-1 is located directly east of Yucca Flat, ER-12-1 is located at the base of Rainier Mesa, and ER-19-2 is located north of Pahute Mesa in the Kawich Valley (refer to Figure 1.1). 
TABLE 3-1 PHYSIOGRAPHIC FEATURES AND ELEVATIONS AT NTS.

\begin{tabular}{|c|c|c|c|c|}
\hline \multirow[t]{2}{*}{ Physiographic Features } & \multicolumn{2}{|c|}{$\begin{array}{l}\text { Minimum Elevation, } \\
\text { mean sea level }\end{array}$} & \multicolumn{2}{|c|}{$\begin{array}{l}\text { Maximum Elevation, } \\
\text { mean sea level }\end{array}$} \\
\hline & m & $\mathrm{ft}$ & $\mathbf{m}$ & $\mathrm{ft}$ \\
\hline \multicolumn{5}{|l|}{ Basins } \\
\hline Yucca Flat & 1,200 & 3,937 & - & - \\
\hline Frenchman Flat & 1,000 & 3,280 & - & - \\
\hline Jackass Flat & 1,100 & 3,609 & - & - \\
\hline Mercury Valley & 1,000 & 3,280 & - & - \\
\hline \multicolumn{5}{|l|}{ Mesas } \\
\hline Pahute Mesa & - & - & 2,256 & 7,402 \\
\hline Rainier Mesa & - & - & 1,848 & 6,063 \\
\hline Buckboard Mesa & - & - & 2,324 & 7.625 \\
\hline \multicolumn{5}{|l|}{ Mountain Ranges } \\
\hline Pelted Range & - & - & 2,354 & 7.723 \\
\hline Mercury Ridge & - & - & 1,608 & 5,276 \\
\hline Halfpint Ridge & - & - & 1,539 & 5,049 \\
\hline \multicolumn{5}{|l|}{ Isolated Mountains } \\
\hline Sbull Mountain & - & - & 1,828 & 5,998 \\
\hline Shoshone Mountain & - & - & 2,154 & 7,067 \\
\hline Yucca Mountain & - & - & 1,930 & 6,332 \\
\hline
\end{tabular}

\subsection{CLIMATE AND METEOROLOGY}

This discussion of climate and meteorology is taken largely from an EA for the LGF Spill Test Facility on Frenchman Flat (Patton et al., 1986). The conditions referred to herein remain substantially the same as the conditions assessed in the $1986 \mathrm{EA}$.

Two major air-movement patterns affect the weather at the NTS. Pacific air flowing over the Sierra Nevada exerts its influence from fall through spring. As the Pacific high-pressure area dissipates in summer, the warm moist air mass in the Gulf of Mexico exerts its influence. Although the precipitation is highly variable, two peaks in annual precipitation can be detected, the larger in winter and the smaller in late summer. The July and August summer rainfall often comes in intense thunderstorms that can cause local flash floods. Table 3-2 shows precipitation (with a coefficient of variation), mean monthly humidity, and evaporation measurements from a standardized pan for the Frenchman Flat area. The average annual precipitation is largely a function of elevation within this region, with higher elevations receiving more than lower elevations. Valley floors average approximately $10 \mathrm{~cm}$ (4 in.) of precipitation per year. The higher mesas and mountains on NTS average 30 


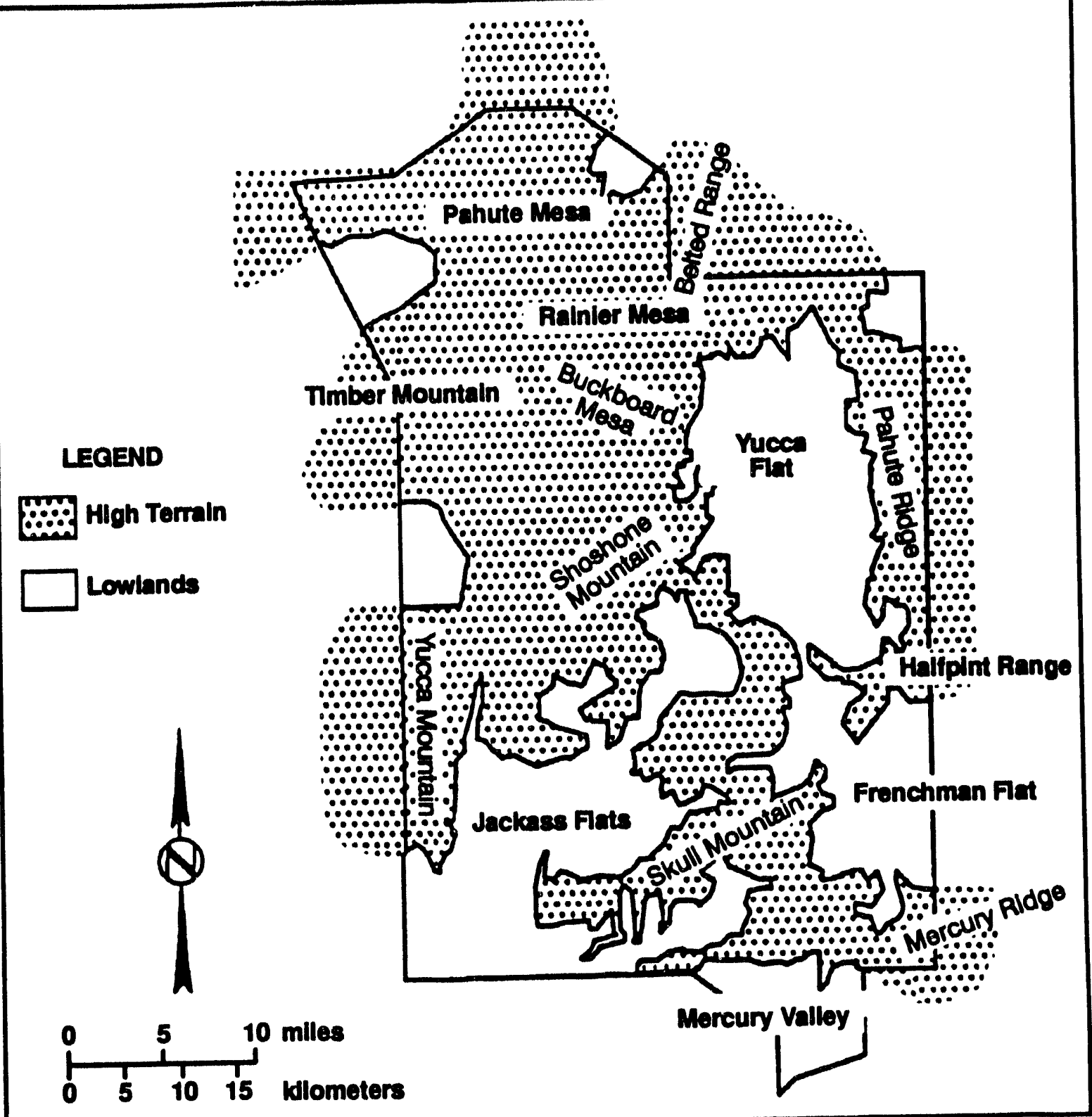

FIGURE 3.1 Physiographic Entities of the Nevada Test Site (Cullen and Russell, 1990).

$\mathrm{cm}$ (12 in.), with some precipitation falling as snow. Standing water on the valley floor is common in winter, with the possibility of a frozen surface.

Average daily temperatures range from $2^{\circ} \mathrm{C}\left(36^{\circ} \mathrm{F}\right)$ in January to $24^{\circ} \mathrm{C}\left(75^{\circ} \mathrm{F}\right)$ in August. Large daily fluctuations in temperature are common, especially on the valley floors. January temperatures at Frenchman Flat vary from $-3^{\circ} \mathrm{C}$ to $12^{\circ} \mathrm{C}\left(27^{\circ} \mathrm{F}\right.$ to $\left.54^{\circ} \mathrm{F}\right)$ during a 24-hour period. July temperatures range from $17^{\circ} \mathrm{C}$ to $36^{\circ} \mathrm{C}\left(63^{\circ} \mathrm{F}\right.$ to $\left.97^{\circ} \mathrm{F}\right)$. 
TABLE 3-2 HUMDITY, EVAPORATION AND PRECIPITATION CONDITIONS OF THE FRENCHMAN FLAT AREA, NEVADA TEST SITE.

\begin{tabular}{lcccc}
\hline Month & $\begin{array}{c}\text { Mean Humidity }{ }^{1} \\
\text { Vapor Pressure (mb) }\end{array}$ & $\begin{array}{c}\text { Pan Evaporation } \\
\text { (mm/day) }\end{array}$ & \multicolumn{2}{c}{ Precipitation $^{3}$} \\
(mm/day) & (c. var.) \\
\hline January & 3.9 & 1.0 & 0.45 & $(1.2)$ \\
February & 4.4 & 2.7 & 0.56 & $(1.4)$ \\
March & 4.5 & 6.1 & 0.40 & $(1.5)$ \\
April & 4.1 & 8.4 & 0.27 & $(1.3)$ \\
May & 3.5 & 11.8 & 0.20 & $(1.2)$ \\
June & 2.7 & 15.9 & 0.16 & $(1.6)$ \\
July & 2.1 & 16.3 & 0.29 & $(1.2)$ \\
August & 2.7 & 15.8 & 0.31 & $(1.2)$ \\
September & 4.0 & 11.8 & 0.28 & $(1.2)$ \\
October & 3.6 & 6.9 & 0.21 & $(1.4)$ \\
November & 2.3 & 3.4 & 0.36 & $(1.2)$ \\
December & 2.7 & 2.0 & 0.40 & $(1.3)$ \\
\hline
\end{tabular}

${ }^{1}$ Measured on Frenchman playa, 1978-1979, coefficient of variation between hourly averages was 0.4 across all months.

2 Pan evaporation as measured by Reynolds Electrical and Engineering $\mathrm{Co}$., Inc., on Frenchman Flat 1956-1958 and Jackass Flat 1967-1969.

${ }^{3}$ Precipitation at Well 5B (E 705,200 N 747,600), elevation $940 \mathrm{~m}$, from 1963-1979. Provided by Richard H. French, Desert Research Institute, Las Vegas, Nevada. Coefficients of variation in parentheses.

${ }^{4}$ Multiply mm/day by 0.03937 to get inches/day.

There are three main influences on the directional wind patterns at the NTS: 1) large-scale movement of major air-pressure systems; 2) intermediate-scale air movements due to regional topographic features; and 3) localized effects due to terrain (Quiring, 1968). As with rainfall, the Pacific air mass influences the winds from fall through spring, while the Gulf of Mexico air mass controls the summer wind pattern. Northerly winds predominate in winter and southerly winds in summer. Since there is a general topographic trend toward higher elevations in the northern portion of the NTS, the differential heating of the surface results in southerly (upslope) winds during the day and northerly (downslope) winds at night. This intermediate-scale effect is most pronounced during the summer; it frequently overrides the large-scale pattern. In turn, this regional pattern is strongly influenced by local terrain effects, especially by the orientation of valleys and ridges (ERDA, 1977).

The annual pattern of wind speeds on the NTS is marked by strong winds in the spring and mild winds in the fall. Ten years of wind data from Yucca Flat show highest monthly average wind 
speeds in April (4 m/s [13 ft/s]) and lowest monthly average wind speeds in November $(2.7 \mathrm{~m} / \mathrm{s}$ [9 $\mathrm{ft} / \mathrm{s}]$ ). Figure 3.2 is an annual wind rose from data collected at Frenchman Flat. It shows the prevalence of strong southwest winds, as well as a secondary peak from strong north winds.

These two peaks are caused by the seasonal patterns over the region which frequently dominate the diurnal pattern. Figure 3.2 was taken from the RCRA Part B Permit Application for the Area 5 RWMS Mixed Waste Management Unit. This document did not contain original hourly meteorological data that would permit seasonal wind roses. However, tabulated wind frequency distributions from 5 years of hourly data from Yucca Flat, collected by the National Oceanic and Atmospheric Administration from 1961-1964, show the same type of annual pattern. Yucca Flat is in a different basin, just north of Frenchman Flat, and seasonal trends are similar, although Yucca Flat data do show a more pronounced northerly component. During the winter (DecemberFebruary), wind patterns at Yucca Flat are dominated by north winds. Winds in the winter are between the northwest and north-northwest directions 58 percent of the time. In contrast, during the summer (June-August), winds are between the northwest and north-northwest directions only 32 percent of the time. Forty-three percent of the time summer winds are from the south-southeast through the southwest. The daily cycle shows little wind at night, increasing wind speeds from morning to afternoon, and declining wind speeds in the evening. Average hourly wind speed may reach $9 \mathrm{~m} / \mathrm{s}$ ( $30 \mathrm{ft} / \mathrm{s})$ on spring afternoons. Wind gusts often are much stronger than hourly averages. Gusts occur throughout the year, but are often recorded in conjunction with late summer thunderstorms. Gusts of $28 \mathrm{~m} / \mathrm{s}$ ( $92 \mathrm{ft} / \mathrm{s}$ ) are noted every few years; very rarely have wind speeds exceeded $45 \mathrm{~m} / \mathrm{s}$ (148 ft/s) (Quiring, 1968; Shinn and Cederwall, 1981).

Yucca Flat data appear to be most representative of GCP Well Sites ER-9-1 and ER-19-2 since both are located in well-exposed valley locations. Well Site ER-EC-2 is located on a mesa top and is more exposed to synoptic winds, but wind patterns are generally the same as for Yucca Flat. Well Site ER-12-1 is protected by a nearby cliff and nearby buildings, so that wind directions are considerably different, and wind speeds generally lower, than the other well sites considered in this EA.

\subsection{AIR QUALITY}

\subsubsection{Ambient Air Quality Standards}

State and National Ambient Air Quality Standards (AAQS) for criteria pollutants, or those pollutants specifically named for review in the Clean Air Act Amendments of 1977, and for which national air quality standards exist, are given in Table 3-3. 


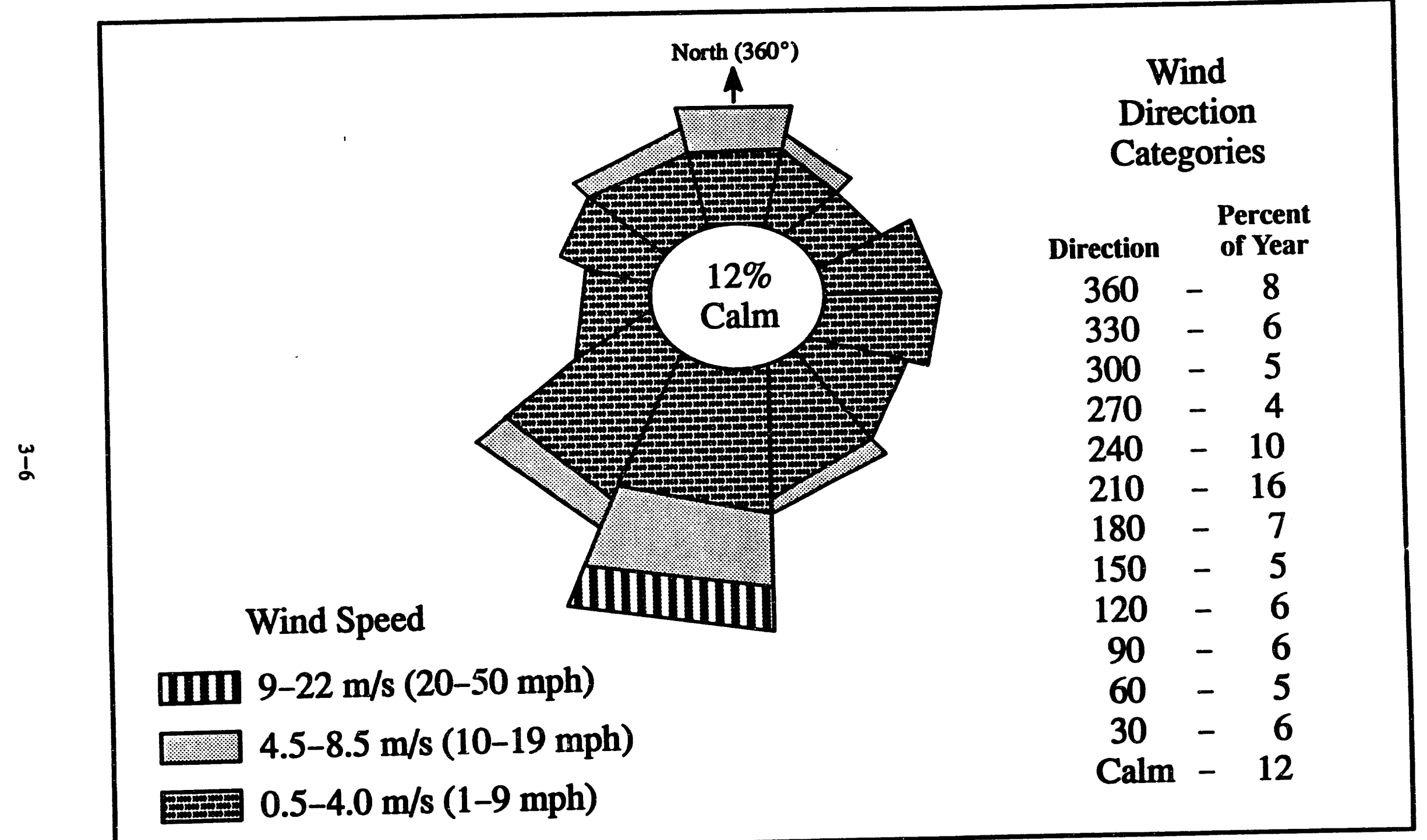

FIGURE 3.2 Annual Wind Rose for Frenchman Flat. Wind Speeds are in Miles Per Hour (from DOE, 1988. RCRA Part B Permit Application). 
TABLE 3-3 AMBIENT AIR QUALITY STANDARDS (MICROGRAMS PER CUBIC METER).

\begin{tabular}{|c|c|c|c|}
\hline \multirow{2}{*}{$\begin{array}{l}\text { Pollutant and } \\
\text { Averaging Time }\end{array}$} & \multicolumn{2}{|c|}{$\begin{array}{l}\text { National Ambient Air } \\
\text { Quality Standards }\end{array}$} & \multirow{2}{*}{$\begin{array}{l}\text { Nevada Ambient Air } \\
\text { Quality Standards }\end{array}$} \\
\hline & Frimary & Secondary & \\
\hline \multicolumn{4}{|l|}{ Sulfur Dioxide } \\
\hline $\begin{array}{l}\text { 3-Hour }{ }^{1} \\
\text { 24-Hour }{ }^{1}\end{array}$ & $\overline{205}$ & 1,300 & $\begin{array}{r}1,300 \\
365\end{array}$ \\
\hline $\begin{array}{l}\text { 24-Hour }{ }^{1} \\
\text { Annual Arithmetic Mean }\end{array}$ & $\begin{array}{r}365 \\
80\end{array}$ & - & $\begin{array}{r}365 \\
80\end{array}$ \\
\hline \multicolumn{4}{|l|}{ Particulate Matter as $\mathrm{PM}_{10}$ : } \\
\hline 24-Hour & 150 & 150 & 150 \\
\hline Annual Arithmetic Mean & 50 & 50 & 50 \\
\hline \multicolumn{4}{|l|}{ Nitrogen Dioxide ${ }^{2}$} \\
\hline Annual Arithmetic Mean & 100 & 100 & 100 \\
\hline \multicolumn{4}{|l|}{ Ozone } \\
\hline 1-Hour ${ }^{2}$ & 235 & 235 & 235 \\
\hline \multicolumn{4}{|l|}{ Carbon Monoxide } \\
\hline 1-Hour ${ }^{1}$ & 40,000 & 40,000 & $\begin{array}{l}40,000 \\
65570^{3}\end{array}$ \\
\hline 8-Hour ${ }^{1}$ & 10,000 & 10,000 & \\
\hline \multicolumn{4}{|l|}{ Lead } \\
\hline Quarterly Arithmetic Mean & 1.5 & 1.5 & 1.5 \\
\hline
\end{tabular}

${ }^{1}$ Short-term national standards ( 24 hours or less) not to be exceeded more than once per year, at any location.

2 Although there are no Nevada or National short-term $\mathrm{NO}_{2}$ standards. California has adopted a one-hour standard of $470 \mu \mathrm{g} / \mathrm{m}^{3}$.

${ }^{3}$ At elevations above $1,524 \mathrm{~m}(5,000 \mathrm{ft}) \mathrm{MSL}$. At lower elevations the Nevada eight-hour CO standard is $10,000 \mu \mathrm{g} / \mathrm{m}^{3}$.

The Environmental Protection Agency (EPA) and the State of Nevada have replaced Total Suspended Particulates (TSP) with $\mathrm{PM}_{10}$, or particulate matter less than or equal to 10 microns in aerodynamic diameter, as the indicator for particulate matter for ambient standards. Nevads adopted a PM 10 standard, which superceded the former TSP standard, on December 26, 1991. The National and State standards are $150 \mu \mathrm{g} / \mathrm{m}^{3}$ for a 24 -hour average and $50 \mu \mathrm{g} / \mathrm{m}^{3}$ for an anmual arithmetic mean. 
The GCP well sites are located within Nevada Intrastate Air Quality Control Region 147 (AQCR-147) and are located approximately between 25 and $75 \mathrm{~km}$ (16 and $47 \mathrm{mi}$ ) from the extreme northwest corner of AQCR-013, the Las Vegas Intrastate AQCR. The Las Vegas Valley Air Basin, in AQCR-013, has been designated a nonattainment area for carbon monoxide (CO). GCP proposed well sites are located in several valleys (air basins) within or adjacent to the NTS. The 1978 EPA review of States' attainment status of National AAQS, which is still applicable, indicates the following status for these air basins for criteria pollutants: Particulate matter $\left(P_{10}\right)$ and sulfur dioxide $\left(\mathrm{SO}_{2}\right)$ are lower than national standards; $\mathrm{CO}$, nitrogen oxides $\left(\mathrm{NO}_{x}\right)$, and ozone $\left(\mathrm{O}_{3}\right)$ are lower than standards or cannot be classified.

\subsubsection{Estimated Air Quality at GCP Well Sites}

DOE believes that present air quality on the NTS is good in most instances, although no data have been collected that give concentrations of the criteria pollutants. There are no significant sources of $\mathrm{SO}_{2}, \mathrm{NO}_{x}$, or $\mathrm{CO}$; the nearest source is Las Vegas, approximately $100 \mathrm{~km}$ (62 mi) to the southeast. $\mathrm{PM}_{10}$ and $\mathrm{O}_{3}$ probably have substantial peak concentrations at times. Measurements of $\mathrm{O}_{3}$ in remote areas of the southwest show increases in the spring and summer months. A late spring maximum 1-hour average $\mathrm{O}_{3}$ concentration of $173 \mu \mathrm{g} / \mathrm{m}^{3}, 74$ percent of the Nevada standard, was observed at a monitoring site $70 \mathrm{~km}$ (44 mi) northeast of Las Vegas. Instances of high particulate concentrations in remote areas are usually caused by high winds which raise amounts of soil particles into the air. These high winds can be either short term in whirlwinds and dust devils, or they can be longer term winds associated with frontal passages. Whatever the cause, the particles put into the air by wind are generally large compared to those produced by combustion, and thus fall out rather quickly when the wind subsides. A rural area in Nevada might typically have an annual average TSP concentration of $25 \mu \mathrm{g} / \mathrm{m}^{3}$ and $\mathrm{PM}_{10}$ typically constitutes 40 percent of TSP. One factor in the amount of $\mathrm{PM}_{10}$ is the degree of disturbance of the land. A natural, high desert area will have less windblown dust than areas where dirt roads have been built or where the soil has been disturbed by agriculture or mining.

\subsubsection{Visibility}

As with other air quality parameters, visibility in remote regions of the southwest is good, but variable. Measurements of visibility have been made to the east and south of the NTS in such areas as the Grand Canyon and southern California desert. Visibility has been found to range between 50 and $350 \mathrm{~km}$ ( 30 and $217 \mathrm{mi}$ ). Lower values are associated with southerly winds, while higher values occur with northerly and westerly winds. Visibility is better during winter than summer. During certain summer periods, most of the southwest United States has hazy conditions with relatively 
low visibility. While the causes of this haze are not completely clear, there is evidence that small particles, transported from urban areas or resuspended from soil surfaces, may contribute (Pitchford et al., 1981). There is also a seasonal effect from smoke particles originating from wild fires in the western United States.

\subsubsection{Toxic/Hazardous and Radioactive Air Emissions}

In addition to criteria pollutants discussed in Sections 3.3.1 and 3.3.2, National Emissions Standards for Hazardous Air Pollutants (NESHAPS) have been established under Section 112 of the Clean Air Act for which EPA has issued proposed or final emission standards for a number of sources: beryllium (Be), mercury ( $\mathrm{Hg}$ ), arsenic (As), vinyl chlorides, benzene, asbestos, and radionuclides. Nevada regulations (NAC 445.717-7205) define a substance as toxic or hazardous if it is listed in "Threshold Limit Values for Chemical Substances in the Work Environment" (ACGIH, 1986). The Nevada Regulation also specifies an "acceptable concentration" to be used as a screening tool, as 1/42 of the Threshold Limit Value, Time Weighted Average (TLV-TWA) where the TWA is for an eight-hour period. As applied to the NTS, the acceptable concentration, as defined in the Nevada regulations, is not to be exceeded at the point of the nearest public residence or public campground.

At present, airborne toxic or hazardous substances, excluding radionuclides, are not found in significant background amounts on the NTS, although some of these materials may be stored underground at the RWMS or may be periodically released locally at the LGF Spill Test Facility at Frenchman Flat.

Radioactivity measurements have been made throughout the NTS for a number of years. Gross beta analysis of air samples, the most useful analysis for detecting trends in gross radioactivity, has been measured at 47 locations around the NTS. Air samples were collected in three ways: 1) continuous particulate and halogen (radioactive) sampling via glass filters and charcoal cartridge to analyze gamma spectroscopy, gross beta, and plutonium; 2) low volume sampling and collection of tritiated water vapor (HTO) using silica gel drying columns to analyze for HTO activity; and 3) continuous low-volume sampling of air, separation, and collection of noble gases (krypton, xenon) using cryogenic-gas chromatographic techniques, to analyze for $85 \mathrm{Kr}$ and $133 \mathrm{Xe}$. In 1985, the highest average from any of these stations was $1.9 \times 10^{-14} \mu \mathrm{Ci} / \mathrm{cc}$, which is about 0.002 percent of DOE's Concentration Guide according to Gonzales (1986). The site average for 47 stations was $1.7 \times 10^{-14} \mu \mathrm{Ci} / \mathrm{cc}$, considered to be normal background for the NTS. Highest average air concentrations of specific radionuclides (Pu-239, Tritium, $\mathrm{Kr}-85$, and $\mathrm{Xe}-133$ ) were much less than 1 percent of the Concentration Guide according to the 1985 monitoring report.

The average dose rate at most of the NTS stations in 1985 was 100 to 160 mrem/year. This is approximately 2 percent of the prospective annual limit for whole-body occupational exposure of 5 
rems in any one year, recommended by the National Council on Radiation Protection and Measurements (NCRP, 1971), and is comparable to the dose rate from ambient ionizing radiation experienced by the population as a whole (EPA, 1976).

\subsection{GEOLOGY AND MINERALS}

\subsubsection{NTS in General}

\subsubsection{Geology}

Because of the underground testing program and the need to ensure geologic containment of test events, the NTS has been subject to numerous geological studies and mapping efforts. The numerous drill holes to depths of $1,000 \mathrm{~m}(3,280 \mathrm{ft})$ and more have provided a rich harvest of geological data to these efforts. The geology of Yucra Flat has been mapped in detail by Barnes et al. (1963); Orkild (1963); Colton and Mckay (1966); Byres and Barnes (1967); Fernald et al. (1968); and McKeown et al. (1976). Frenchman Flat has been mapped by Poole et al. (1965); Poole (1965); and Barnes et al. (1982). Geologic maps of Jackass Flats were presented by McKay and Williams (1964); Ekren and Sargent (1965); and Maldonado (1985). The geology of Pahute Mesa has been mapped by Byers et al. (1966); Carr and Quinlivan (1966); and Orkild et al. (1969). Rainier Mesa has been mapped by Gibbons et al. (1963) and Sargent and Orkild (1973).

In broad tirms, the NTS geologic formations can be grouped in three major categories: 1) Paleozoic carbonate rocks; 2) Tertiary volcanics; and 3) Tertiary and Quaternary alluvium. The distribution of these categories are shown generalized in Figure 3.3. The carbonates are comprised of a series of complexly folded and faulted limestones and dolomites, which are overlain in most places by sequences of Tertiary volcanic tuffs and lava flows. Alluvial and colluvial materials cover most of the NTS, ranging in depth from a few centimeters on the higher areas and slopes to as much as $900 \mathrm{~m}(2,950 \mathrm{ft})$ in the basins. The carbonate rocks range in thickness from hundreds to thousands of meters and have interlayered clastic units. The aggregate thickness of the volcanic rocks is over $1,000 \mathrm{~m}(3,280 \mathrm{ft})$.

The Paleozoic rocks have undergone several deformational events, resulting in a series of north-south oriented thrust faults, accompanied by complex folding, and later normal faulting. The younger volcanic units appear to have been deformed to a much lesser degree. The volcanic rocks have been displaced downward in the basins and have been tilted along steeply dipping normal faults which developed in the late Tertiary.

The Tertiary volcanics are predominantly rhyolitic tuffs that have been ejected from caldera volcanic centers. However, erosion during periods of nondeposition and deposition over varied 


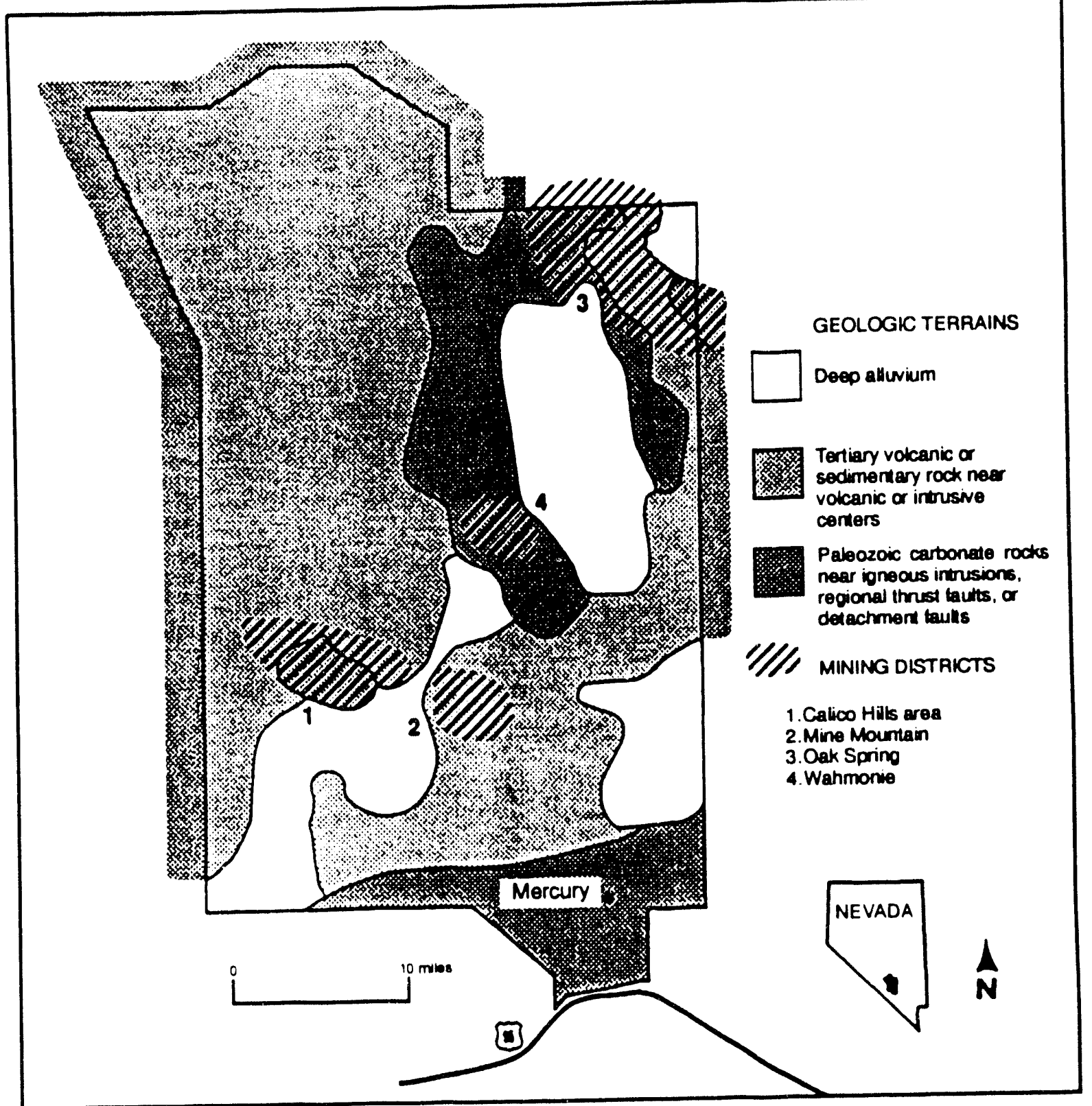

FIGURE 3.3 Geologic Terrains and Mining Districts. Nevada Test Site.

physiography has altered the thickness of most of the sections which have been studied. The majority of the tuffs appear to have originated from the Timber Mountain and Silent Canyon Caldera complexes in the northwestern portion of the NTS.

The alluvial and colluvial sediments appear to have been derived from the erosion of nearby mountains. Geologically, recent faulting has caused offsets in these materials, especially in Yucca Flat along the north-south trending Yucca Fault. Elsewhere, the alluvium appears to be relatively undeformed. 


\subsubsection{Minerals}

As withdrawn land, the NTS is not currently open to mineral exploration or mining. However, prior to the withdrawal several mining districts were established as shown in Figure 3.3. Part of the Calico Hills mining area and all of the Wahmonie mining district are areas of Tertiary volcanic or sedimentary rock cover near volcanic or intrusive centers. Part of the Calico Hills area is composed of Paleozoic carbonate rocks and is addressed separately.

Gold and silver are the only metals likely to have been produced or have potential for production within the volcanic terrain portions of these districts. Volcanic rocks in this portion of the Calico Hills area have not been examined in detail. Surface exposures of volcanic rock exhibit vivid coloration due to bleaching and iron-oxide staining; a sample of this material showed anomalous values in arsenic, antimony, molybdenum, tin, and boron.

The Wahmonie district covers an area of several square kilometers surrounding the old Hornsilver mine in the south-central portion of NTS. Rocks cropping out in the district consist of andesite and latite volcanic rocks that have been extensively hydrothermally altered. This zone of alteration forms an elliptically shaped halo around the old mine workings and can be traced on the surface for about $5 \mathrm{~km}$ ( $3 \mathrm{mi})$ to the northeast and $8 \mathrm{~km}(5 \mathrm{mi})$ to the southwest of the Hornsilver mine (Quade and Tingley, 1984: p. 31-34). Based on available geological, geochemical and geophysical data (Ekren and Sargent, 1965; Hoover et al., 1982; Quade and Tingley, 1984), the Wahmonie district is assessed as having high potential for the development of minable gold/silver resources.

All of two mining districts (Oak Spring and Mine Mountain) and part of one mining district (Calico Hills) are occupied by Paleozoic carbonate rocks associated with igneous intrusions or regional thrust faults (Figure 3.3).

The Oak Spring district covers a large area with a varied geologic environment. Mineralization within the district is related to Mesozoic granitic bodies that crop out at Oak Spring and about $10 \mathrm{~km}(6 \mathrm{mi})$ to the southeast at Twinridge Hill. The zone of alteration and mineralization associated with these plutons includes tungsten-bearing skam deposits contiguous to the Climax stock at Oak Spring and polymetallic vein/replacement deposits at the Michigan Boy and Rainstorm mines to the southeast, near the Twinridge pluton. Examination and reconnaissance sampling of these deposits in 1983 (Quade and Tingley, 1984) indicated that the district has high potential for the development of additional deposits of skarn tungsten mineralization and for discovery of porphyry molybdenum mineralization.

Tungsten-bearing skarn deposits on the east side of the Climax stock were developed in the 1930s and provided the only recorded mineral production from this district. These deposits have not been adequately evaluated, but are believed to contain high potential for the development of 
additional tungsten ore. In addition, there are extensive areas of skarn development on the west and northwest margins of the Climax stock that have high potential for the discovery of tungsten ore. Portions of the area are hidden under post-ore cover of Tertiary ash-flow tuffs. Deep excavations made in the central portion of the Climax stock for the Pile Driver. Tiny Tot, and Hard Hat nuclear tests encountered interesting amounts of molybdenum and copper mineralization associated with fracture-controlled, potassic alteration within the stock. Reconnaissance geochemical sampling in silicified areas of the stock and in the contact zone to the northwest revealed areas of anomalous (high) molybdenum values (Quade and Tingley, 1984).

The Mine Mountain district has historically been prospected for mercury, but the lithologies, structure, and the geochemistry of ores present in the district all strongly fit the generic model of a disseminated gold deposit (Quade and Tingley, 1984).

In the central part of the Calico Hills mining area, small-scale prospecting has been conducted in metamorphosed outcrops of carbonate rocks of the Eleana Formation. Rock outcrops have been altered to weak magnesian skarn and most of the prospecting has been for magnesite. A few small polymetallic vein deposits have also been prospected. Drilling conducted in the Fortymile Wash area by $D O E$ has revealed considerable thicknesses of metamorphic rock at depth, but neither a contact zone nor an intrusive body were found in the drill hole.

\subsubsection{Characterization Well Sites}

Based on regional subsurface geologic knowledge and surficial geology, there are expectations of geologic structure and mineralization to be found at each drill site.

\subsubsection{Site ER-19-2}

This site is located on the northern edge of NTS at the south end of Kawich Valley on valleyfill alluvium. The volcanic rocks of Rainier Mesa are just to the south of the site. There are no nearby drill holes in this area. Alluvium is expected for the first $150 \mathrm{~m}$ ( $490 \mathrm{ft}$ ) below which there will be Tertiary volcanics to a total depth of $914 \mathrm{~m}$ (3,000 ft). The nearest mining district is Oak Springs. located approximately $16 \mathrm{~km}(10 \mathrm{mi})$ to the southeast.

\subsubsection{Site ER-EC-2}

This site is located just to the west of the NTS western boundary on the Nellis Air Force Range. It is situated on the edge of Pahute Mesa within the Timber Mountain Caldera. Numerous deep holes have been drilled within this general area, most located 6 to $10 \mathrm{~km}(4$ to $6 \mathrm{mi})$ to the east. 
Available data indicate that this hole would be drilled entirely within volcanic rocks to a total depth of $1,160 \mathrm{~m}(3,806 \mathrm{ft})$. There are no nearby mining districts.

\subsubsection{Site ER-12-1}

This site is located at the base of Rainier Mesa within Tounge Wash in Area 12. Beneath a shallow mantle of colluvium, the drill hole should encounter Devonian carbonates to a depth of $425 \mathrm{~m}(1,394 \mathrm{ft})$, underlain by the Eleana Formation quartzites to a total depth of $1,070 \mathrm{~m}(3,510 \mathrm{ft})$. The hole would likely bottom in the Eleana Formation, however, the nearest drill hole is about $5 \mathrm{~km}$ (3 mi) distant. The closest mining district is Oak Springs, located approximately $10 \mathrm{~km}(6 \mathrm{mi})$ to the east and across Yucca Flat.

\subsubsection{Site ER-9-1}

This site is located near the summit of the Halfpint Range on the eastern edge of the NTS

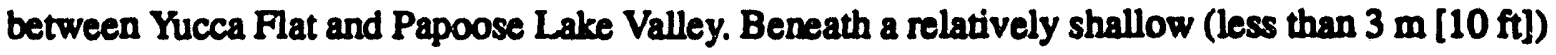
mantle of alluvium, this drill hole may encounter some ash fall tuff to a depth of $90 \mathrm{~m}(295 \mathrm{ft})$, followed by pre-Cambrian quartzite and silt stones to a total depth of $1,005 \mathrm{~m}(3,300 \mathrm{ft})$. There are no nearby drill holes to provide confirmation. This area has been extensively faulted and is geologically quite complex. This site is at the southern edge of the Oak Springs mining district and mineralization may be encountered.

\subsection{HYDROLOGY AND WATER RESOURCES}

Hydrologically, the NTS is a complex region dominated by the effects of aridity and large topographic relief. Perennial surface waters are limited to a small number of low discharge springs. Ephemeral runoff occurs seasonally as the result of springtime snowmelt from the higher mesas and as a result of intense thunderstorms, primarily during the summer. Groundwater beneath the NTS occurs as local perched water tables or regional flow systems. At specific locations, due to material heterogeneity, groundwater conditions can show wide departure from regional trends and relationships.

\subsubsection{NTS in General}

\subsubsection{Surface Water}

Topography controls the direction and flows of surface water both on and from the NTS. Five of the major drainages within the NTS discharge to the Amargosa River and the Amargosa Desert to 
the west and south of the NTS (Figure 3.4). The other six major drainages all terminate in valleybottom playas.

None of the offsite flowing drainages regularly carry water off the NTS, though flash flood flows occasionally discharge from NTS, particularly from Fortymile Canyon. Few flood studies have been done on the NTS and there are no surface water gages. As a consequence, there are few data for flood flow estimates. A flood analysis is currently in progress for drainages from Rainier Mesa in Area 12 and one has been completed for the RWMS in Area 5. The RWMS study indicated potential 100-year flood flows from five Frenchman Flat watersheds ranging from approximately 18 to $260 \mathrm{~m}^{3} / \mathrm{sec}\left(635\right.$ to $\left.9,180 \mathrm{ft}^{3} / \mathrm{sec}\right)$ for watershed areas ranging from approximately 1 to 235 $\mathrm{km}^{2}\left(0.4\right.$ to $\left.90 \mathrm{mi}^{2}\right)$. For Fortymile Canyon, there have reportedly been substantial flood flows but no estimates of quantity have been made. While flood flows may be a concern to the safety of facilities and personnel at NTS, they have only limited relevance to the construction of GCP wells.

Spring flow on NTS is limited to nine low-discharge springs in the eastern and northern portions of the NTS (Figure 3.5). These discharges (ranging from approximately 0.014 to $2.2 \mathrm{l} / \mathrm{sec}$ [0.22 to $35 \mathrm{gpm}$ ]) are believed to be from local perched groundwater systems and show significant seasonal and year-to-year fluctuations. This discharge infiltrates and/or is evapotranspired shortly downstream of the discharge points. These waters are not utilized as supply sources.

\subsubsection{Groundwater}

Occurrence and movement of groundwater at NTS is controlled by the regional geologic structure and by three major geologic classifications (Paleozoic carbonates, Tertiary volcanics and Quaternary valley fill) that have been categorized into several hydrogeologic units (Table 3-4). Groundwater occurs in local perched systems above the regional water table and in broad regional flow systems that flow generally southward beneath the NTS. The local perched systems are fed by locally infiltrated precipitation and they discharge as springs at relatively high topographic elevations near geologic contacts, or by gradually percolated water downward through the underlying unsaturated zone to the regional water table. The regional flow systems are fed by precipitation on higher topographic regions both on and north of the NTS, and they discharge at springs and by evapotranspiration in the Amargosa Desert-Death Valley region south of NTS.

As geologic and hydrologic knowledge of the NTS has increased over the years in association with the testing program, the understanding and description of the regional flow systems has changed. Winograd and Thordarson (1975) produced a potentiometric map for regional flow as shown in Figure 3.6. This surface indicates flow from the Yucca Flat region moving southward through Frenchman Flat, with discharge from the NTS occurring through Mercury Valley to the Amargosa Desert area. In a regional analysis focusing on NTS, Waddell et al. (1984) produced the 


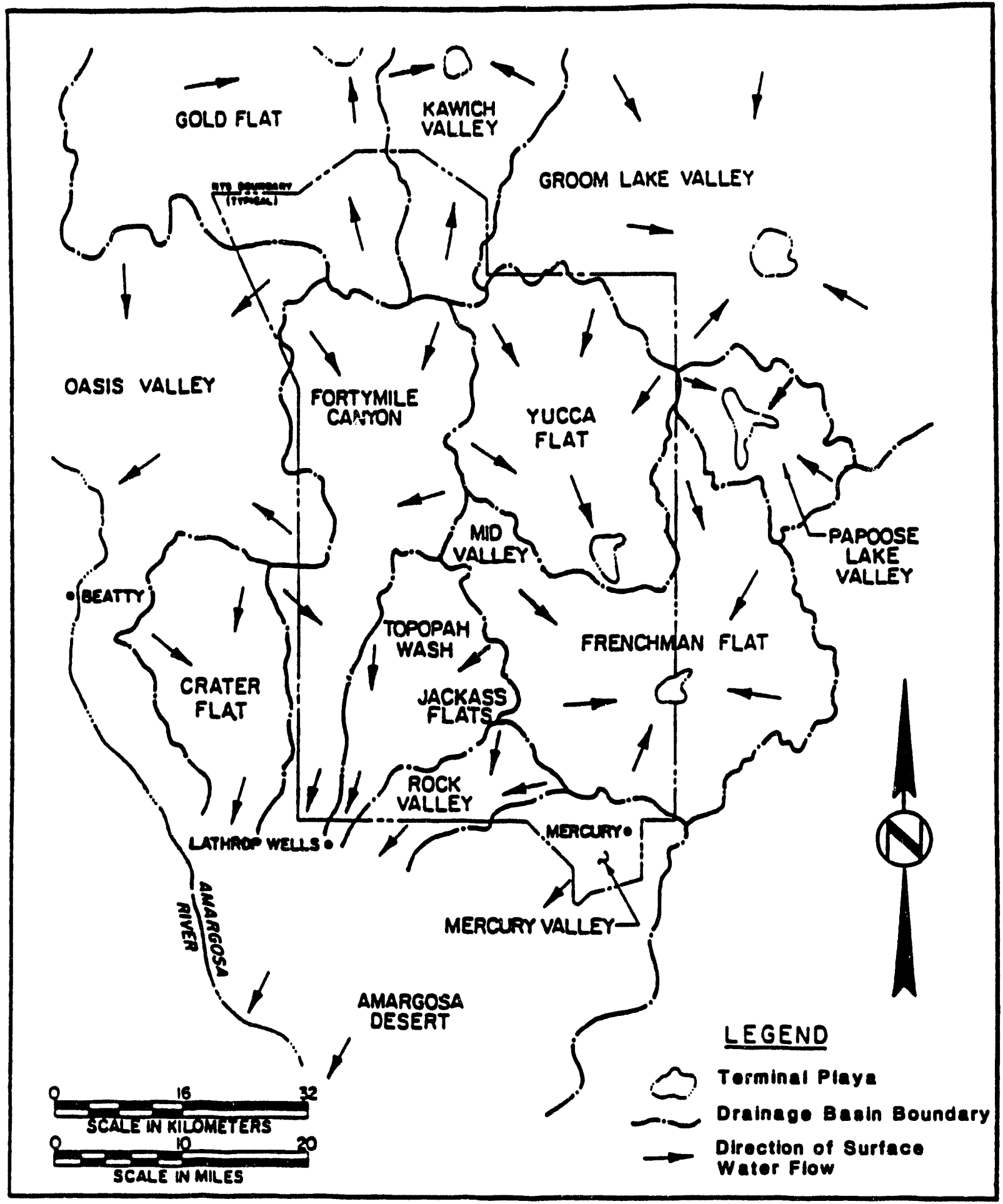

FIGURE 3.4 Boundaries of Basins and Directions of Surface Drainage, Nevada Test Site, Mercury, Nevada (ERDA, 1977). 


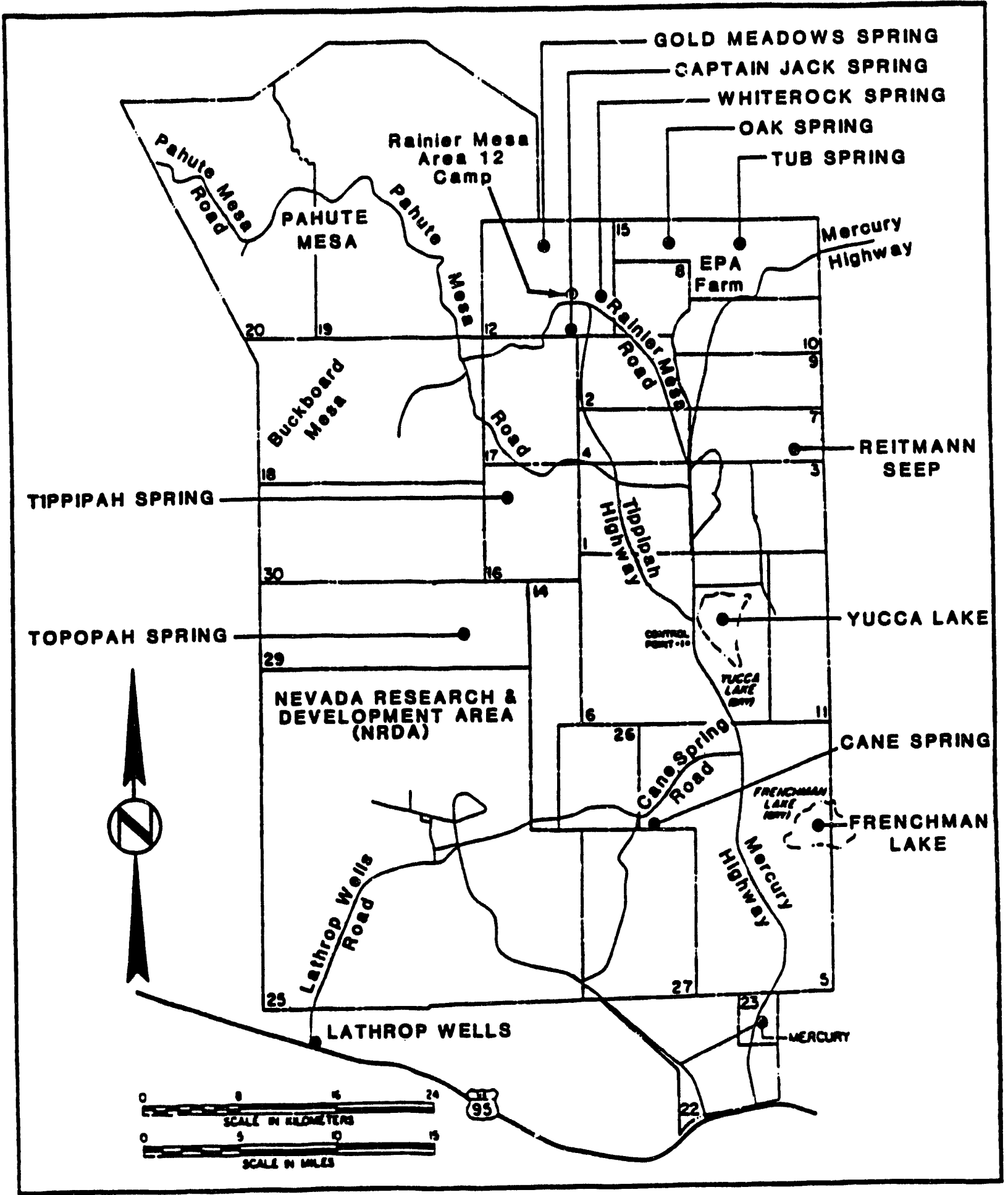

FIGURE 3.5 Natural Surface Water at the Nevada Test Site, Mercury, Nevada (DOE, 1988a). 
TABLE 3-4 HYDROSTRATIGRAPHIC CLASSIFICATION OF PRINCIPAL LITHOLOGIC UNITS ENCOUNTERED ON THE NTS (after Winograd and Thordarson, 1975).

\begin{tabular}{|c|c|c|}
\hline $\begin{array}{l}\text { Geologic Time } \\
\text { Period }\end{array}$ & Stratigraphic Unit & Hydrogeologic Unit \\
\hline \multirow[t]{8}{*}{ Cenozoic } & Valley Fill & Valley-Fill Aquifer \\
\hline & $\begin{array}{l}\text { Basalt of Kiwi Mesa } \\
\text { Rhyolite of Shoshone Mountain } \\
\text { Basalt of Skull Mountain }\end{array}$ & I.ava Flow Aquifer \\
\hline & $\begin{array}{l}\text { Timber Mountain Tuff } \\
\text { Paintbrush Tuff }\end{array}$ & Welded Tuff Aquifer \\
\hline & Informal Bedded Tuff & Bedded Tuff Aquifer \\
\hline & Wahmonie Formation & $\begin{array}{l}\text { Lava-Flow Aquitard/ } \\
\text { Tuff Aquitard }\end{array}$ \\
\hline & $\begin{array}{l}\text { Salyer Formation } \\
\text { Belted Range Tuff } \\
\text { Local Informal Units }\end{array}$ & Tuff Aquitard \\
\hline & $\begin{array}{l}\text { Rhyolite Flow and Tuffaceous } \\
\text { Beds of Calico Hills } \\
\text { Tuff or Crater Flat }\end{array}$ & \\
\hline & $\begin{array}{l}\text { Lithic Ridge Tuff } \\
\text { Rocks of Pavits Spring } \\
\text { Horse Spring Formation }\end{array}$ & \\
\hline Mesozoic & Granitic Stocks & A Minor Aquitard \\
\hline \multirow[t]{3}{*}{ Paleozoic } & Tippipah Limestone & Upper Carbonate Aquifer \\
\hline & Eleana Formation & Upper Clastic Aquitard \\
\hline & $\begin{array}{l}\text { Devils Gate Limestone } \\
\text { Nevada Formation } \\
\text { Undifferentiated Dolomite } \\
\text { Ely Springs Dolomite } \\
\text { Eureka Quartzite } \\
\text { Pogonip Group } \\
\text { Nopah Formation } \\
\text { Bonanza King Formation } \\
\text { Carrera Formation }\end{array}$ & Lower Carbonate Aquifer \\
\hline Pre-Cambrian & $\begin{array}{l}\text { Zabriskie Quartzite } \\
\text { Wood Canyon Formation } \\
\text { Stirling Quartzite } \\
\text { Johnnie Formation }\end{array}$ & Lower Clastic Aquitard \\
\hline
\end{tabular}


TABLE 3-5 HYDROGEOLOGIC PROPERTIES OF MAIOR HYDROSTRATIGRAPHIC UNITS AT NTS (after Winograd and Thordarson, 1975).

\begin{tabular}{lcccccc}
\hline $\begin{array}{c}\text { Hydrostratigraphic } \\
\text { Unit }\end{array}$ & $\begin{array}{c}\text { Transmissivity } \\
\mathrm{m}^{2} / \text { day }(1)\end{array}$ & \multicolumn{2}{c}{$\begin{array}{c}\text { Porosity } \\
\text { Range Median }\end{array}$} & \multicolumn{2}{c}{$\begin{array}{c}\text { Permeability, m/d } \\
\text { Range }\end{array}$} & Median \\
\hline $\begin{array}{l}\text { Lower Carbonate } \\
\text { Aquifer }\end{array}$ & 7 to $>10,000$ & 0 to 9 & 1.1 & $8 \times 10^{-7}$ to $4 \times 10^{-3}$ & $3 \times 10^{-6}$ \\
Wislded Tuff Aquifer & 2.5 to 1,240 & 36 to 50 & - & - & $8 \times 10^{-3}$ \\
Alluvial Aquifer & 10 to 420 & 25 to 50 & - & $2 \times 10^{-1}$ to $2.9 \times 10^{0}$ & - \\
Tuff Aquitard & $<.5$ & 10 to 39 & - & $2 \times 10^{-6}$ to $2 \times 10^{-4}$ & - \\
\hline
\end{tabular}

(1) multiply T[m²/day] $\times 80.94$ to get T[gpd/ft]

potentiometric map shown in Figure 3.7. This portrayal goes well beyond the NTS boundaries and defines three regional flow sub-systems, all discharging to the south and southwest of NTS. These three sub-systems are defined as part of a larger Death Valley regional groundwater flow system. While Waddell et al.'s (1984) work further refines Winograd and Thordarson's (1975) work, the boundaries butween sub-systems are poorly defined due to the sparseness of adequate data.

While these regional flow system descriptions provide a conceptual framework from which to view groundwater movement and the potential transport of contaminants, they belie the hydrogeologic complexity to be found at any given point. Figure 3.8 displays the surface distribution of major rock types at NTS. This region has been complexly folded and faulted and subject to major volcanic activity. As can be seen by comparing Figures 3.7 and 3.8, in general terms, the Ash Meadows Subbasin incorporates primarily the surficial carbonate rocks with some volcanics and alluvium, while the Alkali Flat-Furnace CreekSubbasin incorporates primarily the surficial volcanic rocks with some alluvium. Rociz distribution at depth does not precisely match the surficial expressions but is similar, especially with respect to the mesa volcanics. The hydrogeologic properties of these aquifer and aquiclude materials are very different, but also vary significantly within a unit from point-to-point. Of the major hydrostratigraphic units in Table 3-4, the most important are the lower carbonate aquifer, the welded tuff aquifer, the tuff aquitard and the valley-fill alluvium aquifer (Winograd and Thordarson, 1975). Available hydrogeologic properties of these units are summarized in Table 3-5.

Behavior of these aquifers varies with location on the NTS and can be visualized for the eastern portion of NTS as shown in Figure 3.9. That cross section extends from the central portion of Yucca Flat southward through Frenchman Flat and Mercury Valley. In Yucca and Frenchman Flat, the water table occurs in the alluvium and volcanic rocks overlying the lower carbonate aquifer. In this area, the welded tuff aquifer is believed to overlie the lower carbonate aquifer and, is itself, overlain by the non-welded ash fall tuff aquitard. This aquitard impedes movement of water 


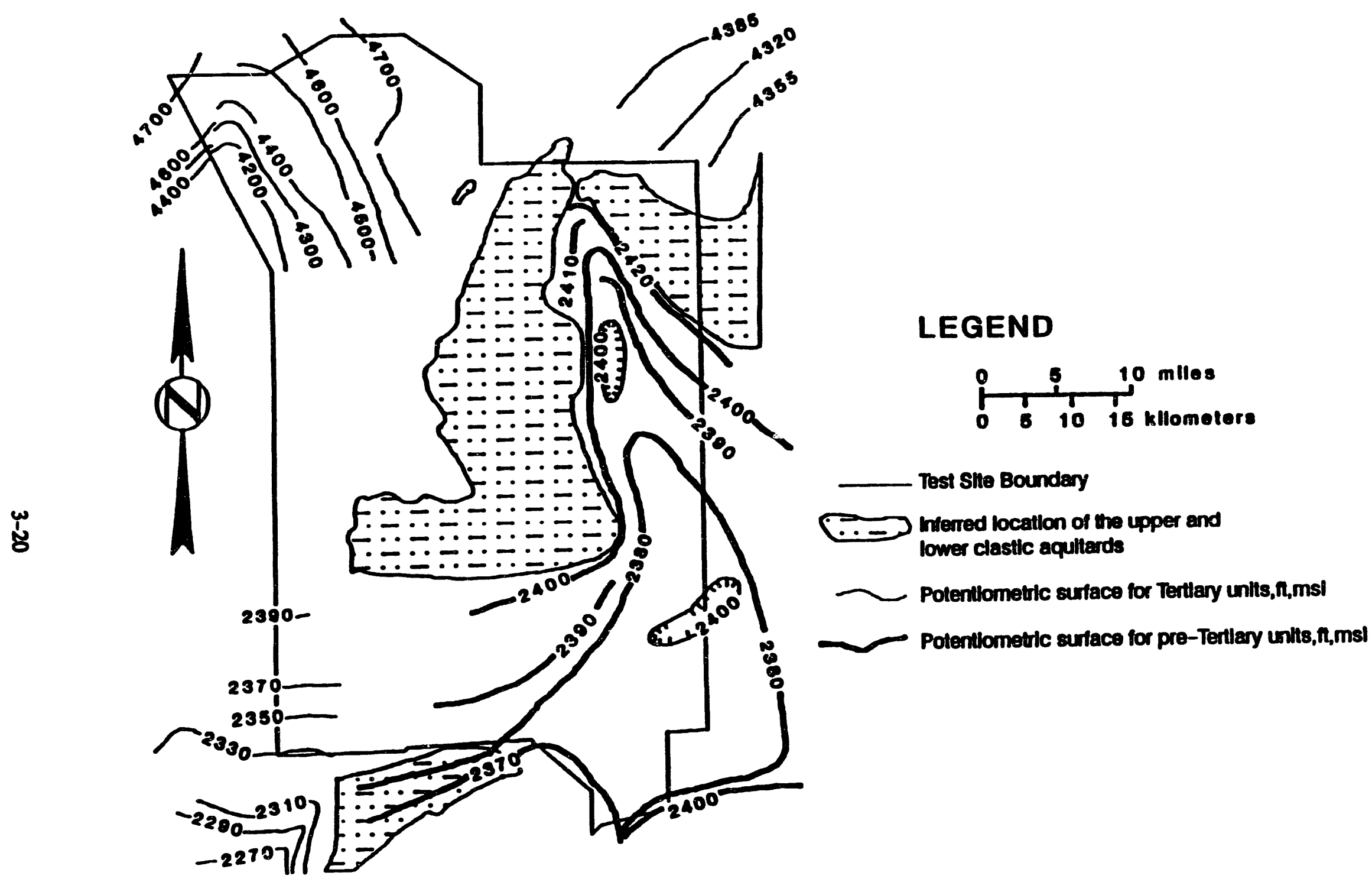

FIGURE 3.6 Composite Potentiometric Contours of the Nevada Test Site (Winograd and Thordarson, 1975). 


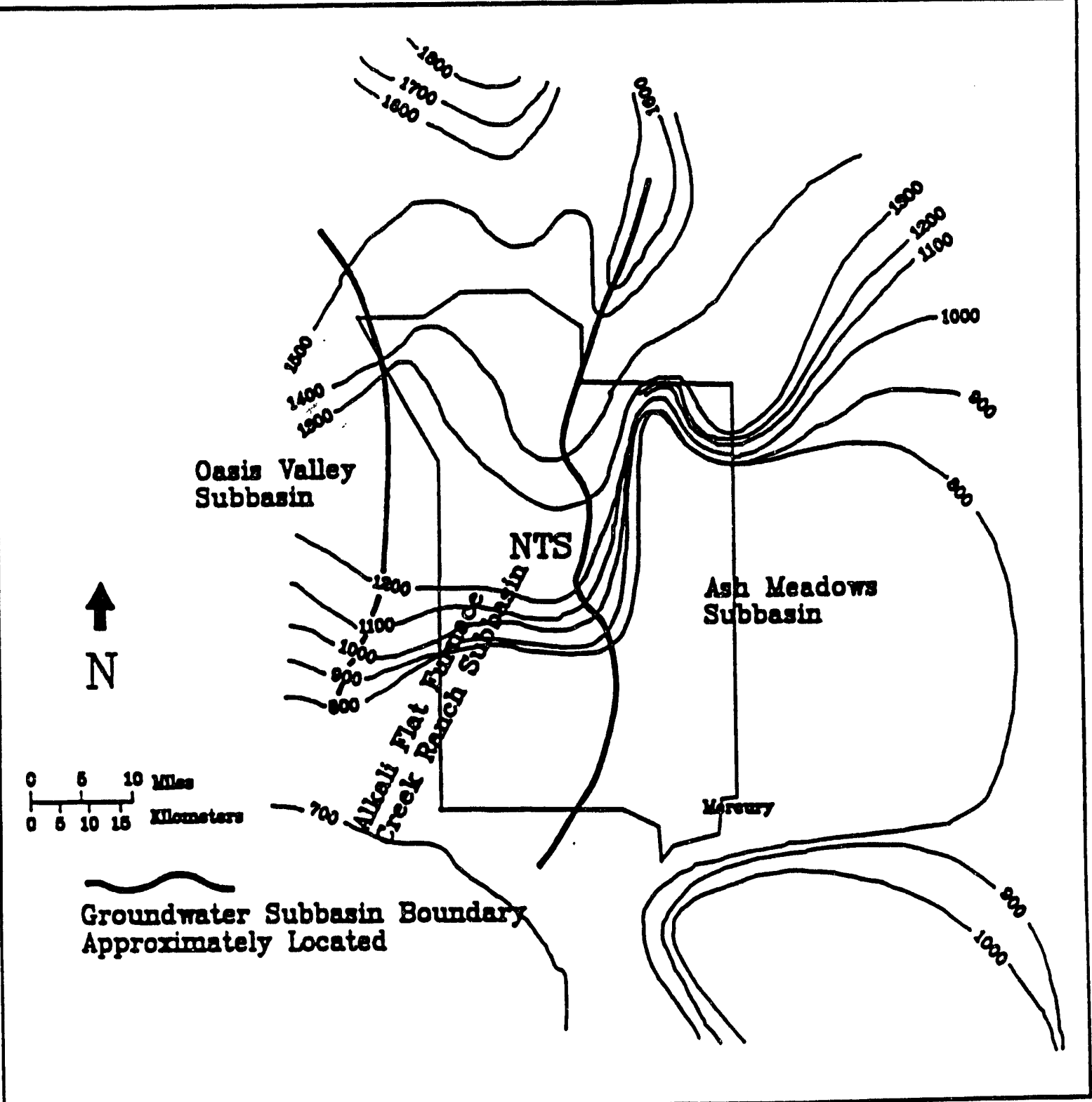

FIGURE 3.7 Composite Potentiometric Surface for the Nevada Test Site (Waddell et al., 1984). 


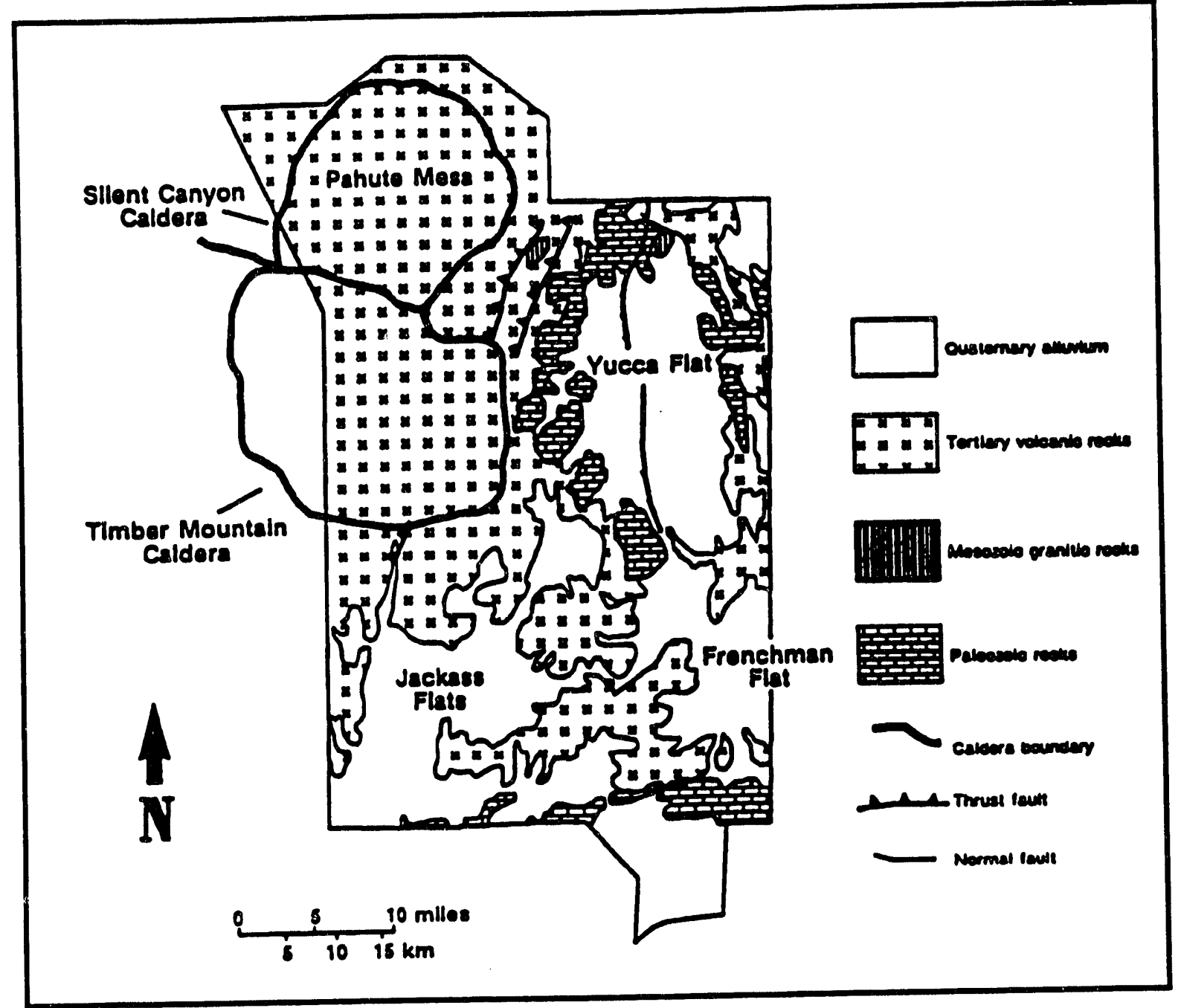

FIGURE 3.8 Major Rock Types on the Nevada Test Site (Cullen and Russell, 1990).

from the alluvium into the underlying aquifers. Low permeability older rocks surrounding the sides of the alluvium restrict horizontal flow in that medium, and thus force slow movement downward into the underlying volcanic and carbonate aquifers and southward. Flow velocities in the lower carbonate aquifer are estimated to be 2 to $180 \mathrm{~m} / \mathrm{yr}$ ( 6 to $590 \mathrm{ft} / \mathrm{yr}$ ) (DOE, 1988a).

Further to the west, beneath Rainier Mesa, the regional water table is in the carbonate aquifer at a depth of nearly $1,100 \mathrm{~m}(3,609 \mathrm{ft})$ below the summit. Above the carbonates, water is perched in fracture zones in the volcanics. This perched water may move slowly downward through the volcanic zone to the carbonates and then to the south or southeast. This perched water also discharges as springs and seeps on the mesa slopes. Rainier Mesa is at or near the western boundary of the Ash Meadows Subbasin shown in Figure 3.7. 


\section{SECTION}

\begin{tabular}{|c|l|l|}
\hline SYMBOL & \multicolumn{1}{|c|}{ GEOLOGICUNIT } & \multicolumn{1}{|c|}{ HYDROGEOLOGIC UNIT } \\
\hline QTal & Quaternary and Tertiary valley fill & Valley-fill aquifer \\
Tt & Tertiary tuff, lakebeds, and lava flows & Welded tuff aquifer and tuff aquitard \\
PzC & Paleozoic carbonate rocks & Lower carbonate aquifer \\
-- & -- & Approx. top of the zone of saturation \\
- & -- & Direction of groundwater flow \\
\hline
\end{tabular}

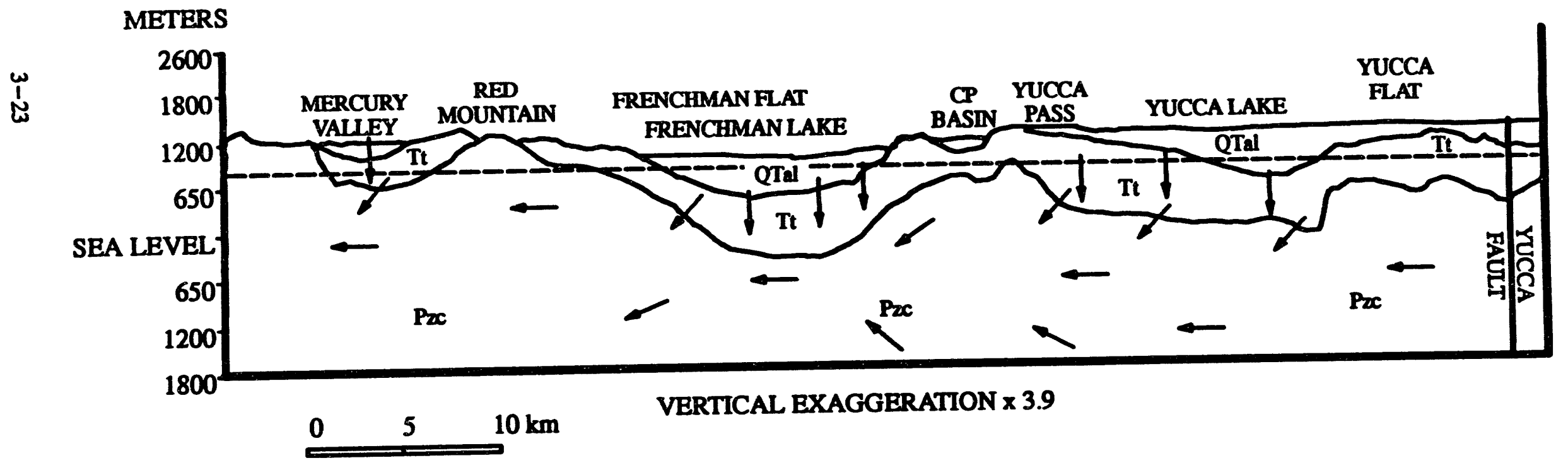

FIGURE 3.9 Generalized Groundwater Flow Beneath Frenchman Flat and Vicinity (after Burbey and Wheatcraft, 1986). 
West of Rainier Mesa, beneath Pahute Mesa, the carbonate aquifers have not been observed. The measured section at Pahute consists of volcanics associated with the Silent Mountain and Timber Mountain Calderas (Figure 3.8). At Pahute Mesa, the interbedded volcanic rocks display extreme contrasts in hydrogeologic properties both vertically and horizontally. Groundwater velocities have been estimated to range from 2 to $76 \mathrm{~m} / \mathrm{yr}$ ( 6 to $250 \mathrm{ft} / \mathrm{yr}$ ), with a most probable velocity of $5 \mathrm{~m} / \mathrm{yr}(16 \mathrm{ft} / \mathrm{yr})(\mathrm{DOE}, 1988 \mathrm{a})$.

A significant problem in interpretation of the NTS hydrogeology is the nature of the hydrologic data. The numerous holes that have been drilled in association with the testing program have provided excellent descriptions of geologic formations encountered and observations regarding which units are saturated. The hydrological concerns with these data are their geographical concentration and the fact that most water level measurements are composite measurements over several water-bearing units. Water chemistries from these holes are also for mixed water from the saturated units. The compositing of these hydrologic data tends to mask gradient relationships between hydrogeologic units, and thus also the directions and rates of groundwater flow.

\subsubsection{Potential Groundwater Contamination}

In the early years of the underground testing program at NTS, there was limited concern for the movement of radioactive isotopes. It was believed that most radioisotopes were contained within the detonation chamber and chimney. Given the estimated low values for groundwater movement, even the most water-mobile isotope, tritium, was not viewed with concern (ERDA, 1977). Several fairly recent studies, however, have cast some doubts on the estimated rates of contaminant movement and movement pathways.

At several drill holes on Yucca Flat, tritium and other nuclides have been found both above and below the water table. At one site, tritium was found at a distance of more than $380 \mathrm{~m}(1,247 \mathrm{ft})$ from the nearest test points within 3 to 8 years of the nearest tests (DOE, 1988a). These data suggest transport velocities of at least 45 to $130 \mathrm{~m} / \mathrm{yr}$ (150 to $426 \mathrm{ft} / \mathrm{yr}$ ) compared to the estimated regional flow velocities in the $5 \mathrm{~m} / \mathrm{yr}$ ( $16 \mathrm{ft} / \mathrm{yr}$ ) range in this flow system. However, it is not clear whether this

rapid radionuclide movement is the result of groundwater transport or the result of other processes such as dynamic injection at the time of the nuclear test.

\subsubsection{Water Supply}

Domestic, industrial, and construction water supplies are provided by 17 active water wells dispersed across the NTS (two other supply wells have been abandoned). Water from the springs and seeps are not used for water supplies due to their low yields. Groundwater is extracted from 
wells completed in alluvium, volcanic, and carbonate rock aquifers. The chemistry of the water varies from a sodium-potassium-bicarbonate dominated water to calcium-magnesiumbicarbonate type water, depending on the mineralogic composition of the aquifers from which the water is extracted. Aquifer tests from a limited number of wells completed in the various rock types on the NTS show a wide range of productivity, with average transmissivities of approximately 100 , 400 , and $160 \mathrm{~m}^{2} /$ day $(8,100,32,400$, and $12,950 \mathrm{gpd} / \mathrm{ft}$ ) (for the alluvial, volcanic and carbonate rock units, respectively) (Winograd and Thordarson, 1975; DOE, 1988a).

Water supply has been developed and is managed on the basis of five service areas that support different NTS operating areas. Locations of the current supply wells are shown in Figure 3.10, recent water use is summarized in Table 3-6, and characteristic water chemistry is summarized in Table 3-7. Given the wastewater disposal practices on the NTS and the depth to the groundwater system, it is reasonable to assume that all of the water pumped on the NTS is consumptively used. and thus no wastewater is returned to the aquifers.

\subsubsection{Characterization Well Sites}

Hydrologic conditions at each well site can only be described in general terms based on surficial conditions, nearby drill holes, and regional relationships. None of the sites are near to, would affect, or would be affected by NTS water supply wells.

\subsubsection{Site ER-19-2}

This site is located on relatively flat alluvial material and there are only shallow drainage features that run to the north. There are no perennial streams nearby. Ephemeral drainage from Kawich Canyon occurs to the east of the site. Depth to groundwater is uncertain, but expected at $990 \pm 150$ $\mathrm{m}(3,248 \pm 492 \mathrm{ft})$, with the water table located in the volcanics.

\subsubsection{Site ER-EC-2}

This site is located on the relatively flat mesa surface with a gentle slope to the west and northwest. A shallow drainage swale is located approximately $100 \mathrm{~m}$ (328 ft) to the north of the site, but carries only occasional snowmelt or rainwater to the mesa's edge. There are no perennial streams. Several boreholes in the general area suggest that the water table would be encountered at a depth of approximately $550 \pm 90 \mathrm{~m}(1,805 \pm 295 \mathrm{ft})$ and would be located in the volcanic welded and fractured tuff.

\subsubsection{Site ER-12-1}

This site is located on the northwestern flank of Tounge Wash just upstream of its confluence with the wash leading from the E Tunnel complex. Both washes are normally dry, but carry water 


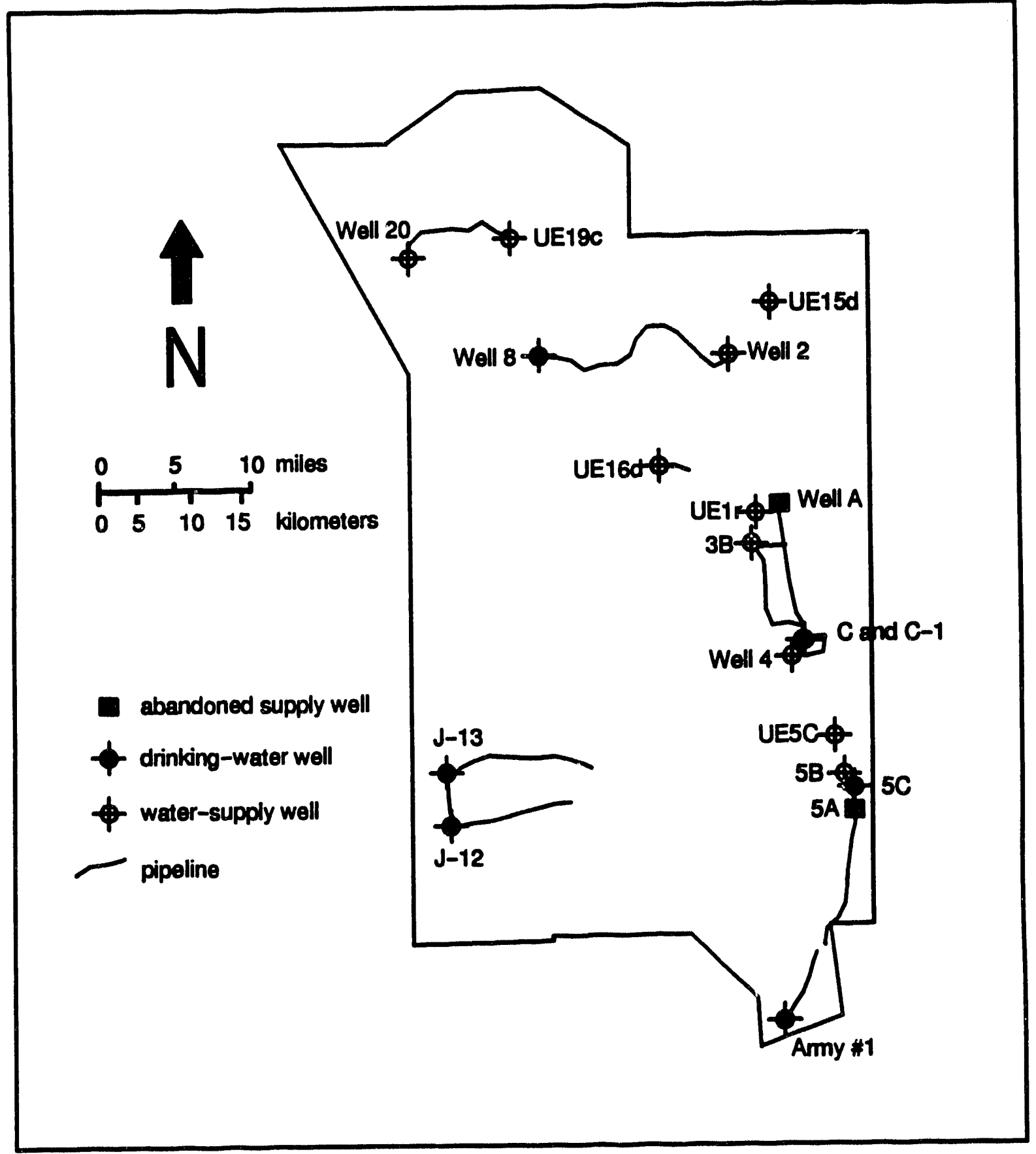

FIGURE 3.10 Water Supply System on the Nevada Test Site (Cullen and Russell, 1990). 
TABLE 3-6 GROUNDWATER USE SUMMARY FOR NTS, 1984-1988.

\begin{tabular}{|c|c|c|c|c|c|}
\hline $\begin{array}{l}\text { Water } \\
\text { Service } \\
\text { Area }\end{array}$ & $\begin{array}{l}\text { NTS Operating } \\
\text { Areas Served }\end{array}$ & $\begin{array}{c}\begin{array}{c}\text { Number of } \\
\text { Production Wells }\end{array} \\
\text { Wells }\end{array}$ & $\begin{array}{l}\text { Primary } \\
\text { Uses }\end{array}$ & \multicolumn{2}{|c|}{$\begin{array}{l}1988 \text { Groundwater } \\
\text { Pumpage, } \\
10^{6} \mathrm{~m}^{3} \text { acre- } \mathrm{ft}\end{array}$} \\
\hline A & 19.20 & 2 & construction & 0.382 & 310 \\
\hline B & $\begin{array}{l}2,4,7,8,9,10,12, \\
15,17,18\end{array}$ & 4 & $\begin{array}{l}\text { domestic \& } \\
\text { construction }\end{array}$ & 0.469 & 380 \\
\hline$C$ (north) & $1,3,6,11$ & 6 & $\begin{array}{l}\text { domestic \& } \\
\text { construction }\end{array}$ & 0.382 & 310 \\
\hline$C$ (south) & $5,22,23,26,27$ & 5 & $\begin{array}{l}\text { domestic \& } \\
\text { fire protection }\end{array}$ & 0.703 & 570 \\
\hline D & 25 & 2 & $\begin{array}{l}\text { domestic \& } \\
\text { construction }\end{array}$ & 0.185 & 150 \\
\hline Totals & & $19 *$ & & 1.121 & 1,720 \\
\hline
\end{tabular}

* two wells currently not used, thus, only 17 active wells.

TABLE 3-7 WATER CHEMISTRY FOR REPRESENTATIVE NTS WATER SUPPLY WELLS (from Claassen, 1973).

\begin{tabular}{lccccccc}
\hline & \multicolumn{7}{c}{ Well } \\
\cline { 2 - 8 } Parameter (1) & Army-1 & $\mathrm{J}-12$ & $5 \mathrm{~B}$ & $\mathrm{C}$ & 2 & 8 & U20az \\
\hline $\mathrm{SiO}_{2}$ & 19 & 54 & 41 & 29 & 44 & 41 & 44 \\
$\mathrm{Fe}$ & $<0.01$ & $<0.01$ & $<0.01$ & $<0.01$ & $<0.01$ & $<0.01$ & $<0.01$ \\
$\mathrm{Mg}$ & 22 & 2.1 & 2.2 & 30 & 14 & 1.1 & 0.2 \\
$\mathrm{Ca}$ & 44 & 14 & 7.0 & 72 & 31 & 8.3 & 5.9 \\
$\mathrm{Na}$ & 37 & 38 & 90 & 120 & 27 & 31 & 55 \\
$\mathrm{~K}$ & 5.2 & 5.1 & 11 & 14 & 6.7 & 3.6 & 2.2 \\
$\mathrm{As}$ & $<0.01$ & - & - & - & - & - & - \\
$\mathrm{HCO}$ & 262 & 119 & 181 & 589 & 197 & 80 & 110 \\
$\mathrm{Fl}$ & 1.0 & 2.1 & 0.7 & 1.1 & 0.4 & 0.8 & 2.8 \\
$\mathrm{Cl}$ & 15 & 7.3 & 21 & 33 & 6.0 & 7.4 & 10 \\
$\mathrm{SO}_{4}$ & 51 & 22 & 52 & 66 & 21 & 14 & 28 \\
$\mathrm{NO}_{3}$ & 0.9 & 7.0 & 11 & 0.1 & 5.1 & 4.3 & 0.7 \\
$\mathrm{TDS}^{2}$ & 301 & 205 & 336 & 628 & 228 & 135 & 194 \\
$\mathrm{pH}$ & 8.0 & 7.6 & 7.9 & 7.5 & 7.8 & 7.4 & 7.9 \\
\hline
\end{tabular}

(1) all concentrations in $\mathrm{mg} / \mathrm{l}$ except $\mathrm{pH}$ which is in $\mathrm{pH}$ units. 
following heavy rainfall or snowmelt. The site is situated above the "normal" stream level on a small alluvia//colluvial finger extending from the adjacent hill slope. Under extreme meteorologic conditions, the site could be subject to flooding. Depth to groundwater is expected to be approximately $495 \pm 300 \mathrm{~m}(1,624 \pm 984 \mathrm{ft})$, with the water table in the Eleana Formation.

\subsubsection{Site ER-9-1}

This site is located in a broad and gently sloping headwater region of a wash flowing westward toward Yucca Flat. Coarse sands and gravels in this area permit relatively rapid infiltration, and thus there is little evidence of erosion or definable stream channels. The site itself slopes gently to the west. There is no perennial stream flow and ephemeral flows would be expected to be small given the location near the headwater boundaries. Depth to groundwater is highly uncertain, but on the order of $365 \pm 300 \mathrm{~m}(1,198 \pm 984 \mathrm{ft})$ with the water table in either the volcanic tuff or pie-Cambrian rocks. There are no nearby drill holes.

\subsection{BIOLOGICAL RESOURCES}

\subsubsection{Vegetation}

The vegetation of the NTS is comprised of the desert shrub associations characteristic of both the Mojave and Great Basin Deserts. A number of vegetation associations containing elements of both deserts are present within a transition zone (Beatley, 1976).

The Mojave Desert is characterized by creosote bush (Larrea tridentata) in association with codominants such as bursage (Ambrosia dumosa), desert-thorn (Lycium andersonii), hopsage (Grayia spinosa), shadscale (Atriplex confertifolia), and four-winged saltbush (A. canescens).

In the transitional areas between the lowlands of the Mojave and Great Basin Deserts, several unique plant associations are present. The bajadas above the Mojave Desert and over the basin floors of the open drainage basins in intermediate elevations are typically occupied by nearly homogeneous stands of blackbrush (Coleogyne ramosissima). The valley floors of the closed drainage basins at the middle and lower elevations are occupied by stands of hopsage and various species of Lycium, occasionally in association with creosote bush.

The Great Basin is largely characterized by big sagebrush (Artemisia tridentata) and black sagebrush ( $A$. nova) in the intermediate elevations and shadscale in association with winterfat (Ceratoides lanata), green molly (Kochia americana), or greasewood (Sarcobatus vermiculatus). At the higher elevations above approximately $1,800 \mathrm{~m}$ (5,906 ft), pinyon (Pinus monophylla) and juniper (Juniperus osteosperma) are present in association with sagebrush. 


\subsubsection{Characterization Well ER-19-2}

Characterization Well ER-19-2 is located at the northern boundary of the NTS on the southern end of Kawich Valley. The site is dominated almost completely by black sagebrush in association with solitary individuals of other species such as mormon tea (Ephedra nevadensis), rabbitbrush (Chrysothamnus sp.), globemallow (Sphaeralcea ambigua), cholla (Opuntia sp.) and perennial grasses. Vegetation cover at this site is approximately 25 percent.

\subsubsection{Characterization Well ER-EC-2}

Characterization Well ER-EC-2 is located on the south edge of Pahute Mesa in a black sagebrush (A.nova) dominated vegetation association. Dominant species associated with the sagebrush include mormon tea, shadscale, joshua tree (Yucca brevifolia), and a herbaceous cover of perennial grasses. Vegetation cover at the site is approximately 35 percent.

\subsubsection{Characterization Well ER-12-1}

Characterization Well ER-12-1 is located at the base of the eastern side of Rainier Mesa in proximity to a desert wash and a broad canyon. The vegetation is dominated primarily by blackbrush, however, there are a number of other species onsite, including mormon tea ( $E$. nevadensis and E. viridis), juniper, pinyon, four-winged saltbush, sagebrush, rabbitbrush (Chrysothamnus sp.), squaw bush (Rhus trilobata), and Lycium sp. Total vegetation cover at this site is approximately 45 percent.

\subsubsection{Characterization Well ER-9-1}

Characterization Well ER-9-1 is located east of Yucca Flat in the general area of the Halfpint Range. The dominant vegetation type at this site is sagebrush. Other species present in the area include hopsage, horsebrush (Tetradymia glabrata), indigo bush (Psorothamnus fremontii), Lycium sp., cholla, and joshua tree. Total vegetation cover at this site is approximately 35 percent.

\subsubsection{Wildlife}

There are at least 46 species of mammals, 190 species of birds, and 32 species of reptiles inhabiting the NTS during a portion of the year, cr year-round (O'Farrell and Emery, 1976). Rodents, including kangaroo rats (Dipodomys spp.), various species of mice, gophers and ground squirrels comprise nearly half of all mammal species and are widely distributed across the NTS. The black-tailed jackrabbit (Lepus californicus) is also widespread on the NTS. Mule deer 
(Odocoileus hemionus) are the most numerous of the large mammals occurring on NTS, inhabiting the sagebrush and pinyon-juniper associations of the high mesas in all seasons except winter. Recent inventories estimated deer populations on Rainier and Pahute Mesa at 1,500 to 2,000 individuals (BLM, 1989). Wild horses (Equus caballus) inhabit portions of the Pahute Mesa area and 1989 surveys estimate their numbers at 40 to 60 individuals.

Most bird species (approximately 86 percent) occurring on the NTS are migrants or seasonal residents. Full-time residents include 7 species of raptors (hawks, owls and eagles), 2 species of game birds (Gambel's quail and chukar), 2 species of woodpeckers, and at least 14 species of passerines (perching or song birds). Spring and summer avian residents include 3 species of raptors and approximately 17 additional species of passerines. In the winter, large flocks of finches, sparrows, larks, and other passerines descend on the NTS for use as winter feeding grounds (O'Farrell and Emory, 1976).

The herpetofauna of NTS includes 1 species of tortoise, 14 species of lizards, and 17 species of snakes (O'Farrell and Emory, 1976). The desert tortoise is discussed in Section 3.6.3.2. Of the lizards, side-blotched lizard (Uta stansburiana), western whiptail (Cnemidophorus tigris), desert horned lizard (Phrynosoma platyrhinos), and desert spiny lizard (Sceloporus occidentalis) are the most abundant and widespread, while the most common snake species on NTS appears to be the western shovel-nosed snake (Chionactis occipitalis).

Wildlife inventories were not conducted for the purposes of this EA. In general, each of the sites provides habitat for many species of wildlife. In particular, sites located in the vicinity of the high mesas may be subject to occasional to frequent use by mule deer or wild horse herds. A large herd of wild horses was observed during the archaeological survey of ER-19-2.

\subsubsection{Sensitive and Protected Species}

\subsubsection{Plants}

There are no plants Federally listed under the Endangered Species Act of 1973, as amended, as threatened or endangered on the NTS. There are, however, eight species of plants that are candidates for listing on the NTS. Beatley's astragalus (Astragalus beatleyae) is the only Candidate, Category 1 (C1) plant species known to occur on the NTS. C1 indicates that substantial information is available to support the biological appropriateness of proposing to list the species as endangered or threatened. However, proposed rules have not yet been issued by the USFWS. Beatley's astragalus is the only plant species occurring on NTS which is on the State of Nevada list of fully protected species. There are also seven Candidate, Category 2 (C2) species occurring on the NTS. $\mathrm{C} 2$ indicates that proposing to list the species is possibly appropriate, but conclusive data on biological vulnerability and threat are not currently available to support the proposed rules. $\mathrm{Cl}$ and $\mathrm{C2}$ 
plant species known to occur on the NTS, habitat characteristics, and known geographic distribution are provided in Table 3-8. In the past, the status of many other plant species was thought to be sensitive enough to warrant candidate or listed status. At present, most of these plants have been reclassified to Category 3, indicating that they are are no longer under consideration. Category 3 plants are not considered in this EA.

Although candidate species are not formally protected under the ESA, DOE policy specifies that preactivity surveys be performed on all construction sites in the event that these species may become listed in the future. Sensitive plant surveys were not conducted for purposes of this EA. although surveys for these species would be conducted prior to construction. The proximity of known plant populations of the eight candidate plant species is described in the following paragraphs.

\subsection{Characterization Well ER-19-2}

Populations of Frasera pahutensis (C2) occur on the southeast ridges of Pahute Mesa and in the Kawich Valley drainage and Kawich Range (Cochrane, 1979). The species is typically located in the higher elevations, in proximity to sagebrush, pinyon and juniper. The proximity of known habitats of the species in the vicinity of Characterization Well ER-19-2 indicates the potential for its presence in the vicinity of the access road to the site.

\subsection{Characterization Well ER-EC-2}

Known populations of Astragalus beatleyae (C1) are scattered along the northwest portion of Pahute Mesa Road and its spurs, in the vicinity of the Thirsty Canyon and Gold Flat drainages (Cochrane, 1979). The species is also known from the general vicinity of Tolicha Peak, Quartz and Black Mountain, and Thirsty Canyon on NAFR (O'Farrell and Collins, 1984). Characterization Well ER-EC-2, which is characterized by a black sagebrush vegetation type, is conceivably located within habitat for this $\mathrm{Cl}$ species.

The Pahute Mesa area also provides habitat for Frasera pahutensis (C2), although populations of this species are known more from the southeast rim of the Mesa; and also for Penstemon pahutensis (C2) which is known from the vicinity of Pahute Mesa Road and Rainier Mesa (Cochrane, 1979).

\subsection{Characterization Well ER-12-1}

Populations of Penstemon pahutensis (C2) are known from the top of Rainier Mesa, between Area 12 Camp and the top of Rainier Mesa, near the saddle between Eleana Range and Rainier 
TABLE 3-8 PLANT CANDIDATES TO THE FEDERAL THREATENED AND ENDANGERED LIST OCCURRING ON THE NTS.

\begin{tabular}{|c|c|c|c|}
\hline Species & & Habitat & Documented NTS Locations \\
\hline $\begin{array}{l}\text { Arctomecon merriami } \\
\text { (C2) }\end{array}$ & $\begin{array}{l}\text { Vegetation: } \\
\text { Physiography: }\end{array}$ & $\begin{array}{l}\text { shadscale, blackbrush, creosote bush } \\
\text { dolomitic limestone outcrops of steep, rough } \\
\text { mountain ranges, flats or old lake beds, shallow } \\
\text { gravelly soil among flat dolomitic rock masses }\end{array}$ & $\begin{array}{l}\text { Spector Range, Spotted Range, } \\
\text { Frenchman Flat, Mercury Ridge, } \\
\text { Mercury Valley drainage }\end{array}$ \\
\hline $\begin{array}{l}\text { Astragalus beatleyae } \\
\quad \text { (C1) }\end{array}$ & $\begin{array}{l}\text { Vegetation: } \\
\text { Physiography: }\end{array}$ & $\begin{array}{l}\text { black sagebrush, pinyon-juniper } \\
\text { volcanic and flatrock outcrops }\end{array}$ & $\begin{array}{l}\text { Pahute Mesa, Thirsty Canyon } \\
\text { drainage, Gold Flat drainage }\end{array}$ \\
\hline $\begin{array}{l}\text { Astragalus funereus } \\
\text { (C2) }\end{array}$ & Physiography: & $\begin{array}{l}\text { sagebrush, hopsage, rabbitbrush, four-winged } \\
\text { saltbush, shadscale, creosote bush, pinyon- } \\
\text { juniper } \\
\text { unstable, usually steep gravelly slopes } \\
\text { of volcanic tuff, occasionally limestone scree }\end{array}$ & $\begin{array}{l}\text { French Peak, Frenchman Flat } \\
\text { drainage, Jackass Divide, } \\
\text { Shoshone Mountain, Mid Valley, } \\
\text { Bullfrog Hills }\end{array}$ \\
\hline $\begin{array}{l}\text { Camissonia megalantha } \\
\quad \text { (C2) }\end{array}$ & $\begin{array}{l}\text { Vegetation: } \\
\text { Physiography: }\end{array}$ & $\begin{array}{l}\text { shadscaie, four-winged saltbush, blackbrush } \\
\text { slopes, cliff bases, loose or compacted } \\
\text { volcanic tuff }\end{array}$ & $\begin{array}{l}\text { Halfpint Range, Cane Spring, } \\
\text { Frenchman Flat, French Peak, } \\
\text { Skull Mountain, west of } \\
\text { Plutonium Valley }\end{array}$ \\
\hline $\begin{array}{l}\text { Frasera pahutensis } \\
\text { (C2) }\end{array}$ & $\begin{array}{l}\text { Vegetation: } \\
\text { Physiography: }\end{array}$ & $\begin{array}{l}\text { sagebrush, pinyon-juniper, mountain mahogany; } \\
\text { flats, volcanic soils }\end{array}$ & $\begin{array}{l}\text { Pahute Mesa (SE ridge), Kawich } \\
\text { Valley drainage, Kawich Range }\end{array}$ \\
\hline $\begin{array}{l}\text { Galium hilendiae var. } \\
\text { kingstonense (C2) }\end{array}$ & $\begin{array}{l}\text { Vegetation: } \\
\text { Physiography: }\end{array}$ & $\begin{array}{l}\text { sagebrush, pinyon-juniper, oak, squawbush; } \\
\text { ravines and gullies, steep talus slopes, } \\
\text { volcanic uuff, loose, rocky soils }\end{array}$ & $\begin{array}{l}\text { South Belted Range, base of Oak } \\
\text { Spring Butte }\end{array}$ \\
\hline $\begin{array}{l}\text { Penstemon pahutensis } \\
\text { (C2) }\end{array}$ & $\begin{array}{l}\text { Vegetation: } \\
\text { Physiography: }\end{array}$ & $\begin{array}{l}\text { sagebrush, pinyon-juniper } \\
\text { open areas, loose gravels, rocky areas among } \\
\text { boulders }\end{array}$ & $\begin{array}{l}\text { Pahute and Rainier Mesa, South } \\
\text { Belted Range, Shoshone Moun- } \\
\text { tain, Fortymile Canyon drainage, } \\
\text { Gold Flat drainage, Eleana } \\
\text { Range, Kawich Valley drainage }\end{array}$ \\
\hline $\begin{array}{l}\text { Phacelia beatleyae } \\
\text { (C2) }\end{array}$ & $\begin{array}{l}\text { Vegetation: } \\
\text { Physiography: }\end{array}$ & $\begin{array}{l}\text { shadscale, creosote bush, bursage, rabbitbrush, } \\
\text { blackbrush } \\
\text { gravels and volcanic tuffs, canyon washes, } \\
\text { loose talus, steep barren slopes }\end{array}$ & $\begin{array}{l}\text { Halfpint Range, Skull Mountain, } \\
\text { French Peak Mountain }\end{array}$ \\
\hline
\end{tabular}


Mesa, below the south rim of Rainier Mesa, on the west slope of Rainier Mesa, from a number of locations along the eastern portion of Pahute Mesa Road, and near the intersection of Stockade Wash Road and Holmes Road (Cochrane, 1979). Characterization Well ER-12-1, which is located in this general vicinity, may be located in the habitat of the species.

\subsection{Characterization Well ER-9-1}

A population of Camissonia megalantha $(\mathrm{C} 2)$ is known in volcanic gravels $5.3 \mathrm{~km}$ (3.3 mi) east of Mercury Highway and $0.6 \mathrm{~km}(0.4 \mathrm{mi})$ east of Barricade $0-1 \mathrm{p}$, on the south side of Papoose Lake Road (Cochrane, 1979). The sagebrush vegetation of Characterization Well ER-9-1 is not indicative of the typical saltbush (four-winged saltbush, shadscale) vegetation in which the species is found. It is possible, however, that this species may be present in the vicinity of the access road leading to the site.

Phacelia beatleyae (C2) has been reported as locally common on the slopes of light-colored volcanic tuff gravel south of Papoose Lake Road, $0.6 \mathrm{~km}$ ( $0.4 \mathrm{mi})$ east of Barricade 9-1p and $5.3 \mathrm{~km}$ (3.3 mi) east of Mercury Highway, North Slanted Buttes, in the blackbrush-horsebrush vegetation type (Cochrane, 1979). Again, the sagebrush vegetation type of this site is not indicative of typical habitat for the species, however, habitat may be present along the access road leading to the site.

\subsubsection{Wildlife}

The Mojave population of th Jrtoise (Gopherus agassizii) was formally listed as a threatened species by the USFWS e. April 2, 1990 (55FR 12178) pursuant to the Endangered Species Act of 1973, as amended. Tortoise habitat is characterized by creosote bush, alkali sink and tree yucca habitats in valleys, on alluvial fans, and in low rolling hills at elevations generally ranging from approximately 600 to $1,200 \mathrm{~m}$ (1,970 to 3,940 ft) above sea level (54FR 32326). Studies conducted during the periods 1981-1986 and 1987-1990 revealed that, relative to overall desert tortoise densities in southern Nevada, desert tortoises are present on the NTS in low to very low abundance. Desert tortoises were found in greatest abundance on the bajadas and foothills of predominantly limestone, dolomite, and shale mountains. Regions having the highest counts of desert tortoise sign ${ }^{1}$ were the CP Hills, Rock Valley, and Mercury Valley. Other areas where tortoises were noted to occur were Yucca Mountain, Massachusetts Mountain/French Peak, and Jackass Flats (DOE, 1991). There are no substantiated records for Yucca Flat or Mid Valley (DOE, 1991; Hunter and Medica, 1987). The four sample well sites discussed in this EA are not located within desert tortoise habitat.

\footnotetext{
"Desert tartoise "sign" coasists of physical evidence of the presence of the animal including, for example. tortoise shells or eggs and fragments thereof, scat (feces), burrows, and pallets (beds). The abundance of sign along transects correlates with the presence and relative abundance of the animais.
} 
The desert tortoise is threatened by loss and degradation of habitat due to construction activities (e.g., roads, pipelines, housing developments, energy developments), mining activities, grazing, and off-road vehicle use. Other important threats to the species include an upper respiratory disease and predation of juvenile tortoises by ravens.

There is one endangered bird species and several candidate bird species that may occur in the vicinity of the NTS. These species include the peregrine falcon (endangered, Falco peregrinus), the ferruginous hawk (C2, Buteo regalis), Swainson's hawk (C2, B. swainsoni), mountain plover (C2, Charadrius montanus), Western snowy plover (C2, C. alexandrinus), white-faced ibis (C2, Plegadis chihi), and long-billed curlew (C2, Numenius americanus). Although peregrine falcons have been sighted on NTS in the past (O'Farrell and Emory, 1976), the likelihood of this species occurring in the area is small. Ferruginous hawks may occur in small numbers during migration and Swainson's hawks may occupy the NTS during the summer months. Plovers, ibis and cirlews are shorebirds that may migrate through the area but would be unlikely to stop at NTS.

\subsection{HISTORIC AND CULTURAL RESOURCES}

The NTS spans the transition between the Mojave Desert and the Great Basin Desert. Consequently, this area also houses a wide variety of plant resources that may have attracted both historic and prehistoric peoples. Most of the southern portions of NTS are covered by Mojave Desert shrub and/or saltbush shrub plant associations, including species historically and prehistorically important such as creosote bush, bursage, shadscale, saltbush, greasewood, joshua tree, Mojave yucca, desert thorn, blackbrush, and spiny hopsage. The mountain ranges in this area are quite arid and generally lack trees, but the numerous perennials and annuals were exploited by hunters and gatherers (Pippin, 1984). The mountains in the northern portion of NTS, on the other hand, support a pinyon-juniper woodland. The bottoms of the valleys in this area support either a saltbush shrub or Great Basin Desert plant association. Historically, important faunal resources on or near the NTS include deer, bighorn sheep, some pronghorn, a variety of rodents, rabbits and reptiles, and several carnivores.

The volcanic substrate in the area provides both silicified tuffs and obsidians that were used as toolstone by prehistoric occupants. Limited outcrops of cherty toolstone occur in the carbonate substrates. Late Quaternary eolian and alluvial deposits that may contain buried cultural resources are generally quite thin and somewhat restricted in their distribution. These deposits are most frequently found on the volcanic mountain ranges and low hills in the region, in the channels of ephemeral drainages, and in and around playas. However, the Quaternary sediments in the region have not been well studied.

The routes of several early explorers and surveyors crossed the area now occupied by NTS. The most famous of these include the Emigrant Trail of the Death Valley Party, the route of 
Governor Blasdel's Party, and Lieutenant George M. Wheeler's route during his mapping of desert lands west of the one hundredth meridian. After that time and prior to its withdrawal in 1941 as part of the Las Vegas Army Air Field School, the area encompassed by NTS was used for mining, grazing, and hunting. Most mining on NTS was an outgrowth of the great gold and silver discoveries at Tonopah, Goldfield, Bullfrog, and Rhyolite during the first decade of the twentieth century (Elliot, 1973). In addition to the numerous, uninventoried prospects and temporary mining camps that resulted from this activity, major mining districts were established at Oak Springs, Mine Mountain, and Wahmonie. Ranching never occurred on a grand scale because of the isolation and extreme aridity of the NTS area. However, small ranches that focused on gathering wild horses were established at the major springs in the area, including Tippipah. Topopah, Cane, White Rock, Captain Jack, Oak, and Tub Springs. Perhaps the most significant historic cultural event ever to occur on the NTS is the testing of nuclear devices which has produced a number of cultural resources which are eligible for the National Register.

\subsubsection{Previous Cultural Resource Studies}

While occasional investigation of the archeology of the NTS occurred previously (Harrington, 1925; Wheeler, 1940; Long, 1950; Shutler, 1961), the first systematic archaeological investigations were conducted in the 1960 's by Frederick C. V. Worman, a biologist with an interest in archeology who worked for Los Alamos Scientific Laboratory. With the help of other archaeologists, he recorded, collected or excavated 26 archaeological sites during that time frame (Worman. 1964; 1966; 1967; 1969). In 1975, the Archaeological Research Center (ARC) of the Museum of Natural History. University of Nevada, Las Vegas conducted preactivity surveys on the NTS as part of a reconnaissance for the U.S. Navy's Seafarer project (EDAW, 1975). Bergin and others from ARC began a study of the NAFR commencing with a literature review in 1978 (Bergin and Roske, 1978). This was followed by a sample survey, sampled by geomorphic features and vegetational zones for most of the NAFR, including Areas 19 and 20 of the NTS (Bergin et al., 1979).

Beginning in 1977 and continuing to the present time, DRI's Quaternary Sciences Center (QSC) (formerly the Social Sciences Center) began conducting preactivity surveys on Yucca Flat and Pahute Mesa for the weapons program and on Yucca Mountain for the Nevada Nuclear Waste Storage Investigation (NNWSI or YMP). In addition to the preactivity surveys, QSC conducted sample reconnaissance of Yucca Flat (Reno and Pippin, 1985). Area 20 on Pahute Mesa (Pippin et al., 1987) and in 1979 initiated one for Pahute and Rainier Mesas. One of the results of the Yucca Flat sample survey was to divide its project area into two strata, one which may contain National Register quality sites (Management Stratum B) and one which is unlikely to contain them (Management Stratum A). This report recommended that preactivity surveys in the Yucca Flat project area 
be conducted only in the stratum which may contain National Register quality sites (Reno and Pippin, 1985: 155-156).

While this Pahute/Rainier reconnaissance was not completed, an overview of the mesas (Pippin, 1986) was in preparation for initiating a systematic, long-range study. This long-range study was implemented by a PA among the ACHP, the Nevada Division of Historic Preservation and Archeology (NDHPA) and the DOE in October of 1990. In summary, this agreement stipulates that the DOE will meet its responsibilities for compliance of $36 \mathrm{CFR}$ part 800 (the National Historic Preservation Act Section 106 process). The Long Range Study Plan (LRSP) stipulates the procedures which will be followed in the mitigation of potential adverse effects to historic properties eligible for inclusion in the National Register under criterion $d$ by systematically studying approximately 100 locations within the boundaries of the Pahute and Rainier Mesas study area. The nature of these studies, the sample units, and the boundaries of the study area are defined in a LRSP for Pahute and Rainier Mesas (Pippin and Henton, 1990). As part of this agreement, projects within the LRSP boundaries which may affect sample study areas must either be altered to avoid them or be delayed until archaeological investigations have been completed. Preactivity surveys will be required to identify cultural resourcs outside of those sample units that may be eligible for inclusion in the National Register under criteria a through $c$.

Programs focused on the identification of resources of cultural-religious value to Native Americans already have been initiated on Pahute and Rainier Mesas and at Yucca Mountain. DOE policy is to encourage tribal participation in DOE programs and this will be followed outside of those areas (DOE Order 1320.2, “American Indian Tribal Government Policy", April 8, 1992).

The approximately 100 proposed characterization well pads would eventually be located throughout or near the NTS. Below are four examples which illustrate the varying levels of existing knowledge and results from different areas.

\subsubsection{Characterization Well ER-19-2}

Characterization Well ER-19-2 is located in an area where few NTS related activities occur, therefore, no preactivity surveys have been conducted nearby. However, this area was included in the area sampled by Bergin in 1978, and four sample units were located within $5 \mathrm{~km}$ (3 mi) of the drill pad and access road (Bergin et al., 1979). Five sites were found in Unit 88, four isolated artifacts and a rockshelter. No sites were found in Unit 116. Two sites were recorded in sample Unit 154 , an isolated artifact and a prehistoric quarry site. Three sites were located at Unit 165, two lithic scatters and a complex of three rockshelters; two with prehistoric artifacts and one with historic artifacts (Bergin et al., 1979: 76, 96, 98). 


\subsubsection{Characterization Well ER-EC-2}

Characterization Well ER-EC-2 is located offsite of NTS, therefore, no preactivity surveys have been conducted in the immediate vicinity although numerous ones have been conducted between 5 and $6 \mathrm{~km}$ ( 3 and $4 \mathrm{mi}$ ) to the northeast and northwest. Clustered at about $5 \mathrm{~km}$ ( $3 \mathrm{mi}$ ) to the northeast are archaeological preactivity surveys for U20ak (Henton, 1984b); U20al (Reno, 1982a); U20ao (Henton, 1984a); U20aq (Henton, 1985); U20at (Reno, 1986a; 1986b; 1986c); U20bb (Reno, 1987); and U20bc (McLane, 1988a). Sixty-eight prehistoric sites were found as a result of these surveys, including four temporary camps, fourteen lithic scatters, seventeen small artifact localities and thirty-three isolated artifacts.

In addition to these preactivity surveys, a 30 percent sample reconnaissance of a $9.75 \mathrm{~km}^{2}(3.8$ $\mathrm{mi}^{2}$ ) area overlapping many of these preactivity surveys was conducted in 1987 . The sample units in this reconnaissance were $120 \mathrm{~m}$ ( $394 \mathrm{ft}$ ) wide, and of various lengths ranging from $2,000 \mathrm{~m}$ to $3,500 \mathrm{~m}(6,562$ to $11,480 \mathrm{ft})$. Twenty-four previously unknown prehistoric sites were discovered during the survey, including three temporary camps, eight artifact localities, and thirteen isolated artifacts (Pippin et al., 1987).

Six kilometers to the north and northwest of Well ER-EC-2, a pad and access road for the HRMP\#3 drill site was surveyed for archaeological sites in 1988 (Livingston, 1988). Twelve archaeological sites were recorded during this reconnaissance, including a temporary camp, three lithic scatters, a knapping station and seven isolated artifacts.

\subsubsection{Characterization Well ER-12-1}

E Tunnel portal, at the end of the access road on which Characterization Well ER-12-1 is located, has not been active in recent years, so no preactivity surveys have been conducted near the portal. Two archaeological reconnaissances, one for each of the portals of $G$ and $N$ Tunnel, have been conducted within the last 6 years. The route of a buried optical fiber communications line from Area 12 Camp to the N Tunnel portal, approximately $1.1 \mathrm{~km}(0.7 \mathrm{mi})$ north of Well ER-12-1, was surveyed in 1985. Only one site was found, a brown jasper biface (Reno, 1984: 2). A $1.67 \mathrm{~km}^{2}(0.64$ $\left.\mathrm{mi}^{2}\right)$ area $1.5 \mathrm{~km}(0.9 \mathrm{mi})$ south of Well ER-12-1 was inspected for archaeological sites in front of the $G$ Tunnel portal. Forty-one archaeological sites were recorded as a result of this survey. Seven of these sites are isolated artifacts or small localities of prehistoric artifacts, which included a Gatecliff and a Rosegate projectile point. Another site is a small lithic scatter. A milling station consisting of three fragments of ground stone and a pile of rocks, which appears to be a hunting blind, make up the remaining small sites. Five of the sites are prehistoric caches composed of one or more rock rings. Four sites are prehistoric campsites, most with groundstone, and some contain brownware pottery, unifaces, and other flaked tools characteristic of these types of sites. The 
remaining 22 sites are historic and probably associated with some limited mining that occurred in the area prior to its withdrawal as a bombing and gunnery range. These sites range from claim cairns to campsites, shafts and adits and, based on still legible claim notices, were active between 1917 and 1939 (McLane, 1988b).

\subsubsection{Characterization Well ER-9-1}

Characterization Well ER-9-1 is beyond the usual area of activities for the NTS, and no preactivity surveys have been conducted in the immediate vicinity. One preactivity survey, drill pad U9cw, and two units ( 29 and 30 ) from the sample survey of Yucca Flat are relatively close, approximately $6 \mathrm{~km}(4 \mathrm{mi})$ to the west. One site, an isolated obsidian dart point base, was discovered during the survey of U9cw (Reno, 1982b). Seven sites were found at sample Unit 29, including three small quarries; two lithic scatters, the first with North Creek Gray pottery; a small artifact locality with a Rose Spring Comer-Notched projectile point; and an isolated bidirectional chert core. Two isolated artifacts were found during the survey of sample Unit 30 , a chalcedony core reduction flake and an obsidian core reduction flake (Reno and Pippin, 1985: Table 5.1).

A relatively large prehistoric temporary camp is located at Reitmann Seep, a small seep located about $4 \mathrm{~km}$ ( $2.5 \mathrm{mi})$ to the southwest of Well ER-9-1. Aside from the debitage scatter, this site includes a prehistoric rock ring feature built of basalt cobbles and a historic trench built to improve the spring flow. Located near the seep is a prehistoric milling station, a prehistoric quarry, and an isolated hearth (Reno and Pippin, 1985: Table 5.1).

\subsubsection{Reconnaissance Methods}

Cultural resource surveys for these sites includes the reconnaissance of the drill pad and access road to the site. Areas surveyed in the vicinity of the proposed drill pad sites were $183 \mathrm{~m}$ by $152 \mathrm{~m}$ ( $600 \mathrm{ft}$ by $500 \mathrm{ft}$ ), and areas surveyed for the right-of-way for the access road were $15 \mathrm{~m}$ ( 50 $\mathrm{ft})$. The length of the access road varies with the site and ranges from about $0.30 \mathrm{~km}(0.2 \mathrm{mi})$ at Characterization Well ER-12-1 to $12.1 \mathrm{~km}(7.5 \mathrm{mi})$ at Characterization Well ER-19-2 for the sample well sites.

Prior to field work, site record and area surveyed files for the NTS maintained at the DRI were consulted to determine if the area had been previously surveyed, or if known archaeological sites exist on the well pad sites or access road locations. In the case of the LRSP area, this check determined if sample units would be affected, and in the case of Yucca Flat, if the project fell within Management Stratum A. For sites outside of the NTS boundaries, the archaeological site and survey records at the appropriate land managing agency were consulted. 
All well site archaeological surveys for drill pads and access roads correspond to a BLM Class III Survey. This class of survey is considered a complete, rather than a sample survey and requires that the surface of the affected areas be systematically inspected by archaeologists walking over the surface of the ground at a distance no greater than $30 \mathrm{~m}$ (100 ft) (Barker, 1990: 7-8). Minimally, archaeologists inspected the well sites walking in parallel transects at a distance less than $30 \mathrm{~m}(100$ $\mathrm{ft}$ ) apart. The access was inspected by walking at least one transect down the center line of the alignment, or on either side of an existing road for the length of any portions of the access that require improvement. Any sites found were recorded using Intermountain Antiquities Computer System (IMACS, 1989) site records and would be registered with the Nevada State Museum or its delegate.

A report, or series of reports, was produced for all of the surveys conducted which meet the criteria of reporting specified by the BLM (Barker, 1990: 13-14). These reports would be forwarded to the DOE who would distribute them to the NDHPA and the ACHP. These procedures would be followed for all future archaeological surveys conducted for the GCP.

\subsubsection{Reconnaissance Results}

\subsubsection{Characterization Well ER-19-2}

Characterization Well ER-19-2 is located towards the southern end of Kawich Valley, northeast of Pahute Mesa. The access to the site is along a north running dirt road from Gold Meadows through Kawich Canyon. At the time that this EA was being prepared, only the pad site and the northern most mile of the access road had been systematically inspected for archaeological sites, although other sites along the route are known from previous surveys or cursory inspections of the road during the initial site selection process.

Three archaeological sites have been found thus far from the systematic survey, an isolated artifact, a small artifact locality, and a temporary camp. A larger prehistoric quarry or temporary camp was recorded previously along the route of the access road (Bergin et al., 1979). Of these four sites, the last two appear eligible to the National Register.

Based on both the recorded and observed sites, it appears that Kawich Canyon contains substantial prehistoric cultural resources which are eligible for the National Register either individually or as a group. Prehistorically, this canyon probably served as a natural route of travel between Kawich Valley and Rainier Mesa, a prime location for pinyon nuts, a staple food crop for aboriginal populations.

\subsubsection{Characterization Well ER-EC-2}

This well site is located on the south rim of Pahute Mesa, west of the Area 20 boundary and overlooking Thirsty Canyon. The access road to the site extends basically south $7.2 \mathrm{~km}$ (4.5 mi) 
from the U20at drill pad. The systematic survey of this pad site and access road has been completed. Four isolated artifacts were found in the pad area, another four isolated artifacts and eight prehistoric archaeological sites were found along the access road.

The eight isolated artifacts included debitage or prehistoric tools, including an Elko CornerNotched type projectile point and several biface fragments. The eight remaining sites are small, low density artifact scatters averaging about 35 to $10 \mathrm{~m}$ (115 to $33 \mathrm{ft}$ ) in size and usually containing less than a dozen artifacts.

Like much of Area 20 to the east, the area of the characterization well pad and access road is quite open and relatively flat. The dominant vegetation is almost pure black sagebrush except at the heads of shallow drainages where juniper have become established. Most prehistoric sites found in this environment are found in shallow drainages or low-lying areas, presumably somewhat sheltered from the winds. The sites found here tend to follow this pattern. In and of themselves, none of the sites found in this reconnaissance appear eligible for the National Register, but National Register quality sites have been found in similar environments in nearby Area 20.

\subsubsection{Characterization Well ER-12-1}

Characterization Well ER-12-1 is located in a relatively steep and narrow side canyon to an unnamed canyon on the east side of Rainier Mesa. Access to this site consists of a short (approximately $25 \mathrm{~m}$ [80 ft]) alignment from an old storage yard. The systematic archacological reconnaissance of this area has been completed. No archaeological sites were found.

\subsubsection{Characterization Well ER-9-1}

Characterization Well ER-9-1 is located near the eastern boundary of the NTS in the Halfpint Range between Yucca Flat and Emigrant Valley. Access to the site east of Yucca Flat is along $9.2 \mathrm{~km}$ $(5.7 \mathrm{mi})$ of dirt road. As of this time, the pad site and all but the eastern most $1.6 \mathrm{~km}$ ( $1 \mathrm{mi}$ ) of road has been systematically inspected. No archaeological sites were found during the inspection of the drill pad site, and only two isolated artifacts and an artifact locality were found along the western 6 $\mathrm{km}(3.7 \mathrm{mi})$ of the access road.

A series of extensive prehistoric archaeological sites were recorded for the next $1.6 \mathrm{~km}(1 \mathrm{mi})$, to the present end of the existing systematic survey. These cultural resources probably continue along the unsurveyed portion of the road. Seven sites have been recorded this far, these sites include prehistoric quarries, lithic scatters, anıo ât least one prehistorically iıhabitecl rock shelter.

As noted above, more archaeological sites are likely to be recorded when the systematic survey of the road is completed. Many of the sites recorded toward the east end on the road appear to be 
eligible for the National Register because of their potential to contribute to the understanding of lithic tool manufacture and general prehistory of an otherwise relatively unknown area.

\subsection{VISUAL RESOURCES}

Issues associated with visual resources typically include compatibility of the proposed action with existing landscape features that provide scenic quauty, and the extent of landscape change that could result from project construction or operation. Visual resources of the NTS are not available for public use, and an inventory of visual resources has not been conducted for the NTS.

\subsection{SOCIOECONOMICS}

The DOE testing program at NTS is extensive both in terms of numbers of people employed and in the size of the annual operating budget. The total NTS operating budget for FY90 was approximately $\$ 1$ billion and accounted for in excess of 5,000 direct jobs in Clark and Nye Counties, Nevada. While the direct employment is significant in the regional economy, it is not major, representing only a little over 1 percent and just under 4 percent of total employment, respectively, in those two counties. 


\subsection{ENVIRONMENTAL CONSEQUENCES}

Adverse effects associated with the GCP include the activities and resource impacts associated with construction and subsequent monitoring of the characterization wells. Activities that may adversely affect the environment of the NTS are the construction of roads, pads and borrow pits, travel to and from drill sites, and the discharge of drilling fluids to the surface and work environment.

All land disturbances would be preceded by preactivity surveys for archaeological and biological resources. Standard DOE drilling practices would substantially reduce potential construction hazards such as contaminated waste releases to the atmosphere or soils from drilling and testing. Sumps would be equipped with liners as needed to prevent seepage. In the unlikely event that non-radioactively contaminated materials, including drilling mud and other well by-products, fuels and lubricants, would be released to the environment, they would be promptly collected and disposed of through DOE standard procedures. If radioactively contaminated materials in excess of DOE radiation protection standards (DOE 5480.11) are encountered during drilling, all contaminated materials and fluids would be diverted to holding tanks. Contaminated materials would be disposed of in accordance with NTS-approved procedures for handling and disposal of radioactively contaminated liquid waste. Drill site location and design would incorporate protection from flash flooding to ensure that stored hazardous and/or radioactive materials are not released to the accessible environment.

Animals are not expected to be vectors for transport of contaminants from drill sites. If an unanticipated problem should arise, appropriate measures such as fencing or covering would be implemented. Thus, there would be no release of radioactively contaminated materials to the surface environment by the GCP. Sanitary wastes, construction debris, and trash would be disposed of in accordance with NTS-approved practices. The program is not expected to generate significant or irreversible resource impacts. Borrow pit areas would be subjected to preactivity surveys, and would be within the estimated total average disturbed area for each well site. To the extent practical. existing borrow pits would be used, and thus few new ones would have to be developed.

\subsection{TOPOGRAPHY AND PHYSIOGRAPHY}

Topographic and physiographic effects are not anticipated as a result of the GCP. In total, a maximum of approximately $730 \mathrm{ha}(1,800 \mathrm{ac})$ of new or improved roadway and borrow pits would be constructed and approximately $40 \mathrm{ha}(100 \mathrm{ac})$ of drill pad sites would be cleared. Total surface area disturbance at each site would be approximately $7.7 \mathrm{ha}(19 \mathrm{ac})$, including pad, sump, and road. Small portions of each well pad would remain cleared to accommodate periodic sampling and testing. Sumps would be left to dry after completion of wells. Unneeded disturbed areas would be reclaimed. Total disturbed area by the approximately 100 -well program, according to geographic areas, is shown in Table 4-1. 
TABLE 4-1 TOTAL DISTURBED AREA BY THE PROJECTED 100 WELIS ACCORDING TO GEOGRAPHIC AREA.

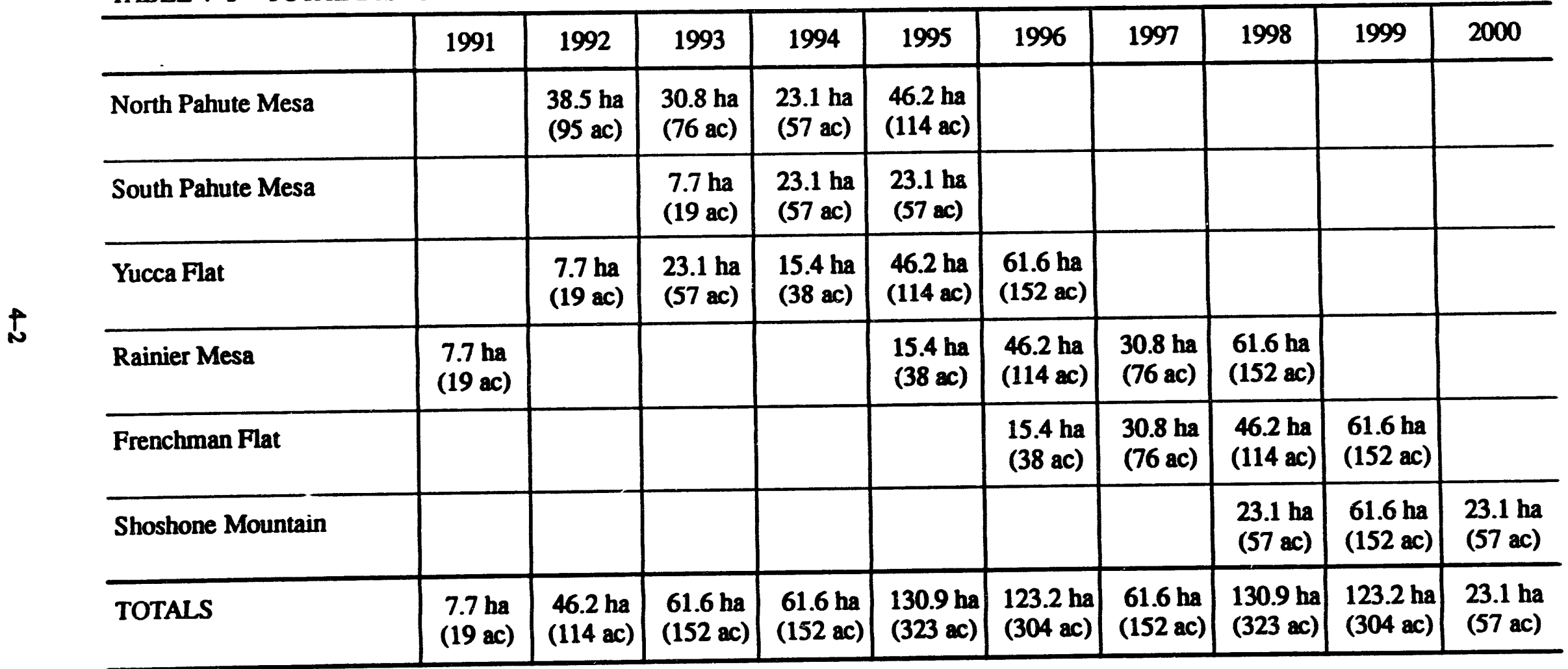


The GCP would result in minor changes to site topography from levelling and excavation operations associated with pad and sump preparation, road improvement, and development of borrow areas. Construction activities would have a very minor effect on topography.

\subsection{CLIMATE AND METEOROLOGY}

The proposed action would not cause any change in local climate or meteorology.

\subsection{AIR QUALITY IMPACTS}

\subsubsection{Nature of Atmospheric Emissions}

\subsubsection{Construction Activities}

Activities during the well construction phase include widening of dirt access roads and pad/ sump pit construction.

During roadwork and construction, which would take an estimated 1 month at each site, the primary air quality impact would be from particulate matter entrained into the air as a result of construction activities and through wind erosion of exposed surface areas. However, water trucks would be used to moisten the soil to reduce airbome particulates during construction. Additional impacts would result from heavy equipment exhaust emissions. There would also be emissions of the pollutants $\mathrm{CO}$ (carbon monoxide), $\mathrm{SO}_{\mathbf{x}}$ (sulfur oxides), and $\mathrm{NO}_{\mathbf{x}}$ (nitrogen oxides) through exhaust emissions from construction vehicles.

\subsubsection{Operational Activities}

During operational activities, primarily drilling, which would take place at each site over a 3 to 4 week period, and testing, which would take place over a subsequent 3 to 4 week period, airborne fugitive dust emissions would be relatively slight and would consist of exhaust emissions from pumps and generators, dust entrained as a result of vehicle travel on dirt surfaces, and wind erosion of exposed surface areas. There would also be $\mathrm{CO}, \mathrm{SO}_{\mathbf{x}}$ and $\mathrm{NO}_{\mathbf{x}}$ emissions from diesel engines used with drills, pumps, air compressors, and other drilling and testing equipment.

Based on geological and mineral studies at drill sites, there is little chance that toxic or hazardous contaminants exist naturally in soils in amounts that could threaten ambient air standards if released into the air from the borehole. There is a possibility that radioactive material exists at water table depths because of the extensive nuclear testing done on the NTS. If such contamination is encountered, drill cuttings and fluids would be diverted to holding tanks, and thus there would be no releases to the surface environment.

\subsubsection{Assessment of the Air Quality Impact of Atmospheric Emissions}

\subsubsection{Method}

This air quality impact assessment of GCP well construction and operation consists of: 1) estimating total emissions, especially particulate emissions, during construction and operational 
(drilling) phases and annual emissions after construction and operations are complete; and 2) estimating the maximum contribution to ambient concentrations resulting from emissions during well construction and operation, in addition to post-operational emissions resulting from surface disturbances, and comparing resulting concentrations with Ambient Air Quality Standards.

Total emissions estimates are based on emission factors for surface disturbances and vehicle/ equipment operation given in EPA AP-42, "Compilation of Air Follutant Emission Factors" (EPA, 1985). For particulate emissions, $\mathrm{PM}_{10}$ is estimated to constitute 40 percent of TSP, unless emission factors were given specifically for $\mathrm{PM}_{10}$. Contributions to ambient concentrations are estimated using modeling methods, specifically through use of the ISCST (Industrial Source Complex Short Term) dispersion model. This model was used because of its utility in modeling point and area source emissions with diurnally variable emission rates. ISCST is a "flat terrain" model, but is appropriate for the present purpose because emissions are close to ground level and impacts occur very near to the source. (This is in contrast to models developed for use in complex terrain where emissions from tall stacks can impact high terrain much further from the source.) Meteorological data consisted of 1 year (1986) of hourly data from Desert Rocl Air Field.

The following sections summarize results from the air quality assessment. Details of emission factor selection and use, and of modeling assumptions and methods, are contained in Appendix $E$.

\subsubsection{Total Emissions}

\section{Construction}

During construction activities, particulate concentrations would occur as a result of fugitive dust emissions during pad construction, access road construction (widening of roads), unpaved road travel on access roads, and wind erosion of exposed pad and road surfaces. Particulate emissions would also result from heavy equipment exhaust. Heavy equipment exhaust is also a source of $\mathrm{CO}, \mathrm{NO}_{\mathrm{x}}$, and $\mathrm{SO}_{\mathrm{x}}$ emissions. $\mathrm{NO}_{\mathrm{x}}$ and $\mathrm{SO}_{\mathrm{x}}$ are estimators for concentrations of the resulting criteria pollutants $\mathrm{NO}_{2}$ and $\mathrm{SO}_{2}$.

The TSP emission estimate for pad construction is based on an assumed pad area of approximately $0.4 \mathrm{ha}(1.0 \mathrm{ac}$ ) (pad area $0.36 \mathrm{ha}[0.9 \mathrm{ac}$ ] plus additional sump pit area of 0.04 ha [0.1 ac]) and a construction period of 1 month. It is also assumed that watering of the construction site would yield a 50 percent reduction in emissions. The TSP emission estimate for widening of access roads is based on the access road length, unique for each site, a road construction rate of 0.8 $\mathrm{km} /$ week ( $0.5 \mathrm{mi} /$ week), and a road width of $12.2 \mathrm{~m}$ ( $40 \mathrm{ft}$ ). Watering as a control measure with 50 percent efficiency is also assumed. Unpaved road travel TSP emission estimates are based on an assumed four vehicles per day during the construction period. Total emissions from construction vehicle exhaust, including $\mathrm{CO}, \mathrm{NO}_{\mathrm{x}}$, and $\mathrm{SO}_{\mathrm{x}}$ emissions, are estimated with the assumptions that 2 dozers. 2 scrapers, 2 blades, 2 water trucks, and 1 roller/compactor would be working continuously on pad construction for 22 eight-hour days during the 1-month construction period, and on road 
construction operating continuously for 5 eight-hour shifts per week over the time period required for the given road length. Wind erosion estimates are based on an exposed pad plus sump pit area of $0.4 \mathrm{ha}(1.0 \mathrm{ac}$ ) and exposed access road areas for $12.2 \mathrm{~m}$ ( $40 \mathrm{ft}$ ) wide roads with lengths unique to each site. Total wind erosion estimates are made for a 1-month construction period.

Total TSP emissions from construction activities for each site, and for uncontrolled and controlled (through watering) conditions are summarized in Table 4-2. Total TSP emissions are dominated by access road construction and wind erosion and are thus highly variable with respect to road length. Total controlled emissions for construction activities vary from 17.2 tons for Site ER-19-2 (access road length $12.1 \mathrm{~km}$ [7.5 mi]) to 1.5 tons for Site ER-12-1 (access road length 0.3 $\mathrm{km}[0.2 \mathrm{mi}])$.

Table 4-3 shows total $\mathrm{CO}, \mathrm{NO}_{\mathrm{x}}$, and $\mathrm{SO}_{\mathrm{x}}$ emissions from heavy equipment exhaust. These also vary according to access road length.

\section{Operations}

During operations (drilling, testing), particulate, $\mathrm{CO}, \mathrm{NO}_{\mathbf{x}}$, and $\mathrm{SO}_{\mathbf{x}}$ emissions would result from fugitive dust emissions associated with road travel on unpaved access roads and vind erosion of exposed surfaces, and from diesel combustion emissions from pumps, generators, and other well drilling and testing equipment.

Fugitive dust emission estimates for unpaved road travel are based on 10 vehicles per day for 50 workdays (25 days of well drilling, 25 days of well testing). Wind erosion fugitive dust emissions are estimated in the same way as for construction activities, but for a 10-week period. Diesel engine exhaust emissions are related to hp-hours of operation. It is assumed that the following diesel-fueled equipment mix, based on information supplied by project engineers, would be operating continuously for 24 hours/day, for 25 workdays during well drilling.

\begin{tabular}{|c|c|c|}
\hline Equipment & Number & $\begin{array}{c}\text { Total Rated } \\
\text { Horse Power (HP) }\end{array}$ \\
\hline Drill Rig & 1 & 530 \\
\hline Air Compressors & 2 & 970 (485 each) \\
\hline Mud Pump & 1 & 485 \\
\hline Sump Pump & 1 & 99 \\
\hline $330 \mathrm{KW}$ Generator & 1 & 485 \\
\hline $40 \mathrm{KW}$ Generator & 1 & 80 \\
\hline TOTAL & & $\overline{2,649}$ \\
\hline
\end{tabular}

It is also assumed that a work-over rig with a 300-HP diesel engine would be operated 8 hours per day for 25 days during well testing.

Total TSP emissions from operational activities are summarized in Table 4-4. These are dominated by wind erosion of exposed access road surface areas and are thus variable according to 


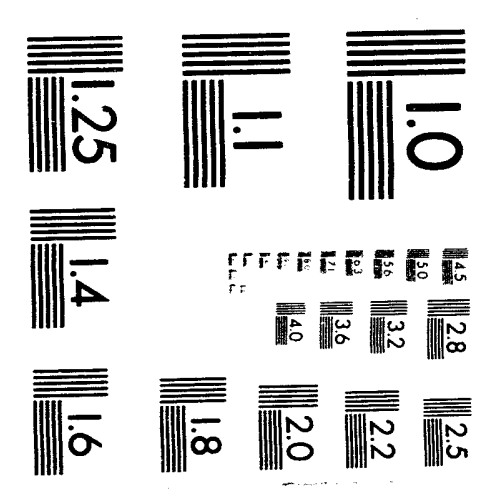



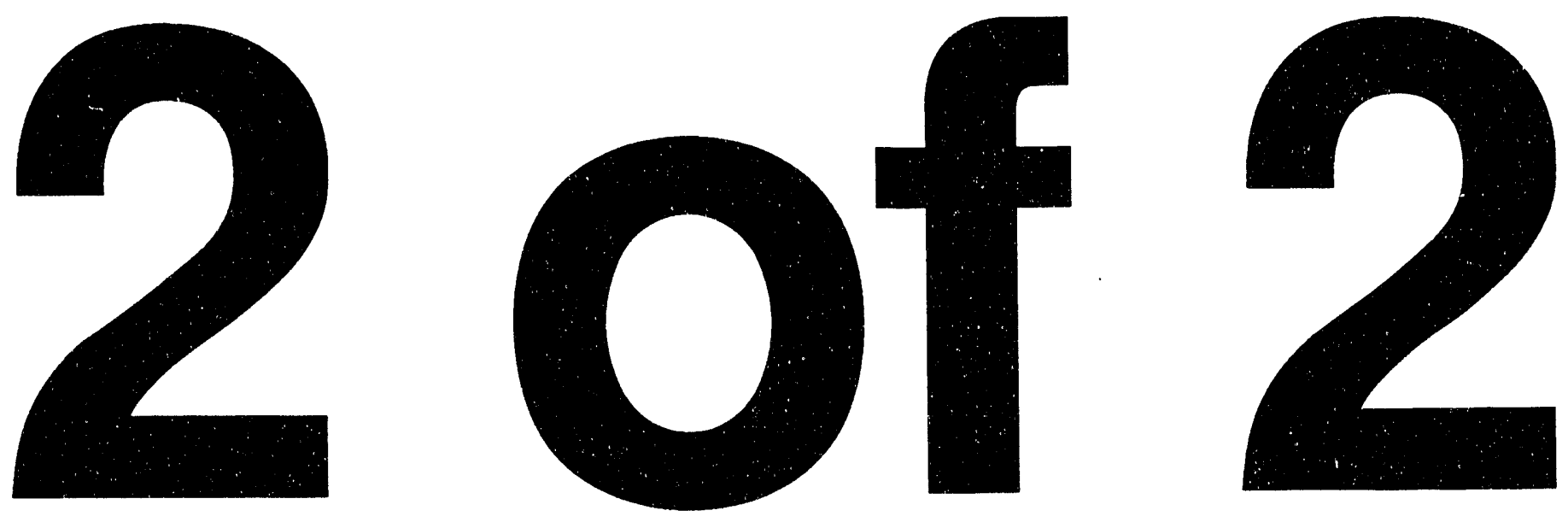
TABLE 4-2 TSPa EMISSIONS (TÖNSS) FROM CONSTRUCTION ACTIVITIES.

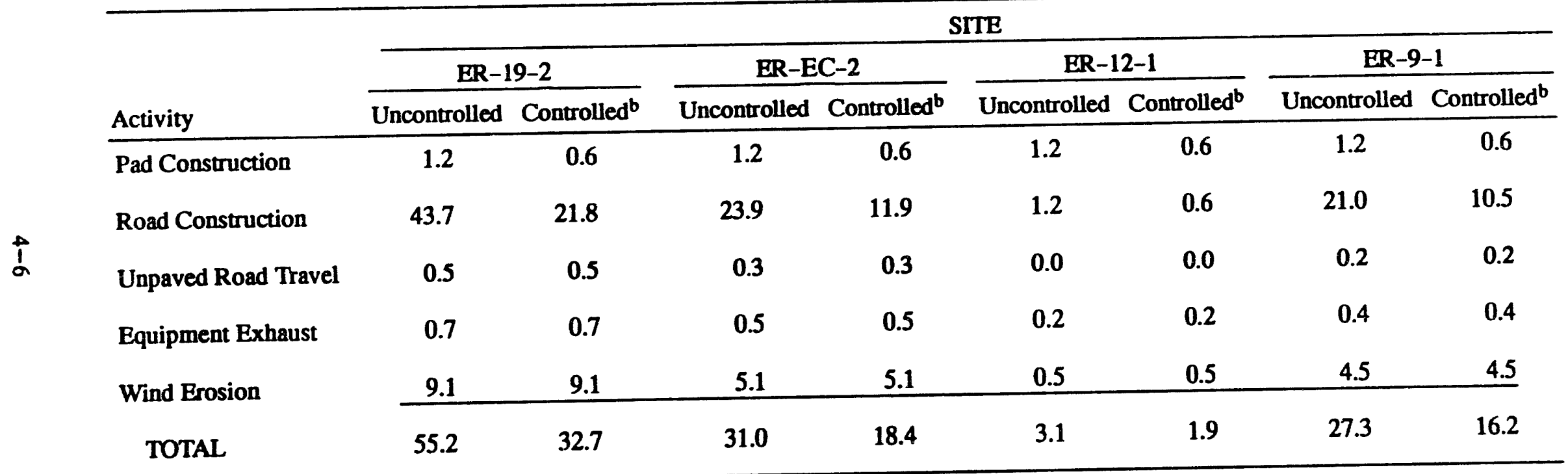

a For comparison, $\mathrm{PM}_{10}$ emissions may be estimated as 40 percent of TSP emissions.

b Control consists of twice-daily watering with an assumed efficiency of 50 percent. 
TABLE 4-3 HEAVY EQUIPMENT EMISSIONS (TONS) DURING CONSTRUCTION ACTIVITIES.

\begin{tabular}{lcccc}
\hline & \multicolumn{4}{c}{ SITE } \\
\cline { 2 - 5 } Pollutant & ER-19-2 & ER-EC-2 & ER-12-1 & ER-9-1 \\
\hline CO & 3.9 & 2.5 & 0.9 & 2.3 \\
$\mathrm{NO}_{\mathbf{x}}$ & 10.3 & 6.7 & 2.5 & 6.1 \\
$\mathrm{SO}_{\mathbf{x}}$ & 1.1 & 0.7 & 0.3 & 0.7 \\
\hline
\end{tabular}

access road length. Estimated total TSP emissions during the operational phase vary from 25.5 tons for Site ER-19-2 to 3.0 tons for Site ER-12-1.

TABLE 4-4 TSPa EMISSIONS (TONS) FROM OPERATIONAL ACTIVITIES.

\begin{tabular}{lcccc}
\hline & \multicolumn{4}{c}{ SITE } \\
\cline { 2 - 5 } \multicolumn{1}{c}{ Activity } & ER-19-2 & ER-EC-2 & ER-12-1 & ER-9-1 \\
\hline Unpaved Road Travel & 2.6 & 1.4 & 0.1 & 1.2 \\
Wind Erosion & 21.1 & 11.8 & 1.1 & 10.4 \\
Diesel Equipment & $\frac{1.8}{25.5}$ & $\frac{1.8}{15.0}$ & $\frac{1.8}{3.0}$ & $\frac{1.8}{13.4}$ \\
$\quad$ TOTAL & 25
\end{tabular}

a For comparison, $\mathrm{PM}_{10}$ emissions may be estimated as 40 percent of TSP emissions.

Total $\mathrm{CO}, \mathrm{NO}_{\mathbf{x}}$, and $\mathrm{SO}_{\mathbf{x}}$ emissions from diesel-fueled internal combustion engines during the operational phase are summarized in Table 4-5. These estimates are identical for each site as they are independent of access road length. They are based on emission factors for $\mathrm{NO}_{\mathbf{x}}$ and $\mathrm{SO}_{\mathbf{x}}$, as estimators of maximum contributions to ambient $\mathrm{NO}_{2}$ and $\mathrm{SO}_{2}$ concentrations.

TABLE 4-5. TOTAL EMISSIONS (TONS) FROM DIESEL-FUELED DRILLING AND TESTING EQUIPMENT DURING OPERATIONAL PHASE.

\begin{tabular}{cc}
\hline Pollutant & $\begin{array}{c}\text { Total Emissions } \\
\text { (tons) }\end{array}$ \\
\hline $\mathrm{CO}$ & 5.5 \\
$\mathrm{NO}_{\mathbf{x}}$ & 25.4 \\
$\mathrm{SO}_{\mathrm{x}}$ & 1.7 \\
\hline
\end{tabular}




\section{Total Annual Emissions}

Total annual emissions, after the construction and operational phases are completed, would be almost exclusively from wind erosion of exposed surfaces (access road, pad, sump pit), with very minor contributions from occasional vehicle traffic. Annual emissions are thus variable according to access road length. Estimated TSP emissions from wind erosion are shown in Table 4-6. Total particulate emissions estimates vary from 110.2 tons/year for Site ER-19-2 to 5.8 tons/year for Site ER-12-1.

\section{Total Incremental Emissions}

An estimate of total annual emissions resulting from the drilling and operation of 100 wells over a 5 to 10 year period was made on the basis of emissions from an "average" site and two different well construction rate scenarios. In the first scenario, Scenario A, it is assumed that one drilling rig would be in use and the program would be completed in 10 years, at a rate of 10 wells/year. In the second scenario, Scenario B, it is assumed that two drilling rigs would be available to complete the program in 5 years, at a rate of 20 wells/year. "Average" site emissions are averages of total emissions from the four sites considered above.

"Average" site and incremental emission rates are detailed in Table 4-7. For Scenario B, with 20 wells/year, the annual incremental TSP emission rate is estimated to be 1,790 tons/year (upper limit). After completion of the 100 -well program, subsequent particulate emission rates resulting from wind erosion of exposed surfaces are estimated to be 5,800 tons/year for TSP and 2,320 tons/ year for $\mathrm{PM}_{10}$, as upper limits.

These incremental and post-operational emission rates would be spread out over a large area comprising most of the NTS. In the case of TSP, much would settle out before being transported long distances. Also, unless there are two or more well sites within approximately $2 \mathrm{~km}(1.2 \mathrm{mi})$ of each other, local concentrations resulting from GCP well construction and operation would originate from only one GCP well site.

TABLE 4-6 TOTAL ANNUAL POST-OPERATIONS PARTICULATE EMISSIONS FROM EXPOSED ACCESS ROAD AND SUMP PIT AREAS.

Total Particulate

Site Emissions (tons/year)

$\begin{array}{lr}\text { ER-19-2 } & 110.2 \\ \text { ER-EC-2 } & 61.6 \\ \text { ER-12-1 } & 5.8 \\ \text { ER-9-1 } & 54.4\end{array}$


TABLE 4-7 INCREMENTAL TOTAL CONTROLLED EMISSIONS FOR 100-WELL PROGRAM.

\begin{tabular}{|c|c|c|c|}
\hline \multirow[b]{2}{*}{ Phase/Pollutant } & \multirow[b]{2}{*}{$\begin{array}{l}\text { "Average" } \\
\text { Site (tons) }\end{array}$} & \multicolumn{2}{|c|}{ Incremental Rate (tons/year) } \\
\hline & & $\begin{array}{l}\text { Scenario A, } \\
10 \text { Wells/Year }\end{array}$ & $\begin{array}{l}\text { Scenario B, } \\
20 \text { Wells/Year }\end{array}$ \\
\hline \multicolumn{4}{|c|}{ Construction Phase } \\
\hline TSP & 17.3 & 173 & 346 \\
\hline $\mathrm{PM}_{10^{2}}$ & 6.9 & 69 & 138 \\
\hline $\mathrm{CO}$ & 2.4 & 24 & 48 \\
\hline $\mathrm{NO}_{\mathbf{x}}$ & 6.4 & 64 & 128 \\
\hline $\mathrm{SO}_{\mathrm{x}}$ & 0.7 & 7 & 14 \\
\hline \multicolumn{4}{|l|}{ Operational Phase } \\
\hline TSP & 14.2 & 142 & 284 \\
\hline $\mathrm{PM}_{10} \mathrm{a}^{\mathrm{a}}$ & 5.7 & 57 & 114 \\
\hline $\mathrm{CO}$ & 5.5 & 55 & 110 \\
\hline $\mathrm{NO}_{\mathbf{x}}$ & 25.4 & 254 & 508 \\
\hline $\mathrm{SO}_{\mathrm{x}}$ & 1.7 & 17 & 34 \\
\hline \multicolumn{4}{|c|}{$\begin{array}{l}\text { Post-Operational Phase } \\
\text { (First Year) }\end{array}$} \\
\hline TSP & 58.0 & 580 & 1,160 \\
\hline $\mathrm{PM}_{10^{\mathrm{a}}}$ & 23.2 & 232 & 464 \\
\hline \multicolumn{4}{|l|}{ TOTALS } \\
\hline TSP & 89.5 & 895 & 1,790 \\
\hline $\mathrm{PM}_{10^{8}}$ & 35.8 & 358 & 716 \\
\hline $\mathrm{CO}$ & 7.9 & 79 & 158 \\
\hline $\mathrm{NO}_{x}$ & 31.8 & 318 & 636 \\
\hline $\mathrm{SO}_{\mathrm{x}}$ & 2.4 & 24 & 48 \\
\hline
\end{tabular}

a $\mathrm{PM}_{10}$ Mass estimated as 40 percent of TSP mass.

\subsubsection{Short-Term Concentrations (Construction)}

Highest short-term particulate emissions, especially fugitive dust emissions, would occur during the construction phase of approximately 1 month per site. Maximum possible contributions to short-term ( 24 hours or less) ambient concentrations are thus estimated by modeling of emission rates for a typical construction day scenario. Modeled sources consist of area sources representing $\mathrm{pad} / \mathrm{road}$ construction and wind erosion, and a point source representing construction equipment exhaust emissions. For pad/road construction, a square area source of $0.5 \mathrm{ha}(1.2 \mathrm{ac})$ was used to represent the pad area and current road construction area. The TSP emission rate for this area source is estimated by assuming that monthly total emissions are spread uniformly over 22 eight-hour days to get an average emission rate in $\mathrm{g} / \mathrm{s} / \mathrm{m}^{2}$, and that watering provides 50 percent control. Road/ pad emissions are zero except for hours $0900-1700$ each day. Wind erosion is simulated as a square 
$0.5 \mathrm{ha}(1.2 \mathrm{ac})$ area source with an emission rate based on the daily emission factor for active storage piles, averaged over 24 hours/day.

Maximum contributions to ambient $\mathrm{CO}, \mathrm{NO}_{2}$, and $\mathrm{SO}_{2}$ concentrations would occur as a result of construction equipment exhaust during the construction phase and from diesel-fueled internal combustion engines (pumps, generators, etc.) during the operational phase. Thus, two scenarios are used to estimate maximum contributions of these pollutants. Equipment exhaust emissions are simulated as a point source representing emissions from two dozers, two scrapers, two blades two water trucks, and one roller/compactor operating eight hours/day, i.e., exhaust emissions are zero except for 0900-1700 each day. Diesel-fueled internal combustion engine emissions are simulated as a point source representing the same equipment mix listed in Section 4.3.2.2, except with only one 485-HP air compressor. For maximum (upper limit) estimates, it is assumed that this equipment would be in continuous full-power operation 24 hours/day.

The center of the area sources, and the point source, were collocated at the center of a $2 \mathrm{~km} \mathrm{x}$ $2 \mathrm{~km}(1.2 \mathrm{mi} \times 1.2 \mathrm{mi})$ grid, with a simulated receptor spacing of $100 \mathrm{~m}(330 \mathrm{ft})$. All simulated receptors are at $2 \mathrm{~m}(6.6 \mathrm{ft})$ above ground level. One year (1986) of meteorological data from Desert Rock Air Field was used to estimate maximum short-term concentrations at each receptor.

Resulting maximum contributions to short-term ambient concentrations are summarized in Table 4-8. These maxima all occur at nearby receptors, at distances of $100 \mathrm{~m}$ to $150 \mathrm{~m}$ (330 $\mathrm{ft}$ to $490 \mathrm{ft}$ ) from the grid center and all occur as a result of 24 hours/day emissions from diesel-fueled equipment during the operational phase. Table 4-8 gives maximum contributions for each pollutant/averaging period having an air quality standard, and the percent of that standard. All contributions are well below the corresponding standard. These numbers have considerable uncertainty

TABLE 4-8 MAXIMUM CONTRIBUTIONS TO SHORT-TERM AMBIENT CONCENTRATIONS (DIESEL, ENGINES DURING WELL DRILLING).

\begin{tabular}{lcc}
\hline $\begin{array}{c}\text { Pollutant and } \\
\text { Averaging Time }\end{array}$ & $\begin{array}{c}\text { Contribution } \\
\left(\mu \mathrm{g} / \mathrm{m}^{3}\right)\end{array}$ & $\begin{array}{c}\text { Percent of } \\
\text { Standard }\end{array}$ \\
\hline $\begin{array}{l}\mathrm{PM}_{10}{ }^{\mathrm{a}} \\
\text { 24-Hour }\end{array}$ & 65 & 43 \\
$\mathrm{SO}_{2}$ 3-Hour & & \\
24-Hour & 810 & \\
$\mathrm{CO}$ & 151 & 41 \\
1-Hour & & \\
8-Hour & 6,042 & 15 \\
\hline
\end{tabular}

a Estimated as 40 percent of TSP contribution. 
associated with crude emission factors, Gaussian modeling methods, and conservative assumptions such as 24 hours/day full-power operation of diesel equipment, but this does indicate that ambient standards are unlikely to be exceeded. The maximum $\mathrm{PM}_{10}$ contribution, estimated as 40 percent of the maximum TSP contribution, is about 40 percent of the standard.

\subsubsection{Annual Average Concentrations}

After well construction, drilling, and testing operations are finished, subsequent emissions would be essentially limited to wind erosion of exposed areas. The impact, in terms of contributions to annual average particulate concentrations, is estimated through modeling of a single 0.5 ha (1.2 ac) source, to represent the GCP site and exposed access road nearest the site. The emission rate is estimated in the same way as for short-term contributions in the construction phase described above:

The annual average concentration contribution from wind erosion is estimated with the ISCST model using the 1-year Desert Rock Air Field hourly meteorological data base. The resulting maximum contribution to annual average TSP concentrations is $2.4 \mu \mathrm{g} / \mathrm{m}^{3}$. The corresponding $\mathrm{PM}_{10}$ annual average, assuming $\mathrm{PM}_{10}$ mass to be 40 percent of the TSP mass, is about 1.0 $\mu \mathrm{g} / \mathrm{m}^{3}$, or about 2 percent of the National and Nevada annual average $P M_{10}$ standard of $50 \mu \mathrm{g} / \mathrm{m}^{3}$.

\subsubsection{Conclusions}

The total emissions estimates given in this section are based on very general emission factors having significant associated uncertainties. Concentration estimates, using the ISCST model, are also based on these emission factors, and have additional uncertainties associated with generalization of emission factors for emission rate estimates and the inherent uncertainty of Gaussian plume modeling. Total emissions and emission rate estimates are based on generally conservative assumptions, however. Considering the uncertainty of estimates and conservatism of results, the following conclusions are drawn:

1. Total fugitive dust emissions in the construction phase would be highly dependent upon exposed surface area and, for sites with lengthy access road requirements, would be dominated by road construction dust.

2. Total fugitive dust emissions in the operational phase would be dominated by wind erosion of exposed surfaces and would be thus highly correlated with access road length. At sites with minimal access road requirements, fugitive dust emissions are much less and are dominated by diesel exhaust emissions.

3. Now that Nevada has changed to the same $\mathrm{PM}_{10}$ standard that the EPA has established as a national standard, there would probably be no exceedance of any air quality standards as a result of construction activities. 
4. Annual average concentration standards would not be exceeded as a result of GCP well construction and operation.

\subsection{GEOLOGY AND MINERALS}

The GCP is not expected to have any adverse geologic or mineral resource effects. Any effects would be beneficial in that the drilling program would provide new knowledge on regional geology and possibly on the occurrence of valuable minerals.

\subsection{HYDROLOGY AND WATER RESOURCES}

The GCP program is not expected to have any adverse effects on either the regional hydrologic regime or the NTS water supply system. Wells to be drilled would isolate various saturated strata penetrated, and thus prevent possible interaquifer communication or contamination following well completion. Information gained from these holes would add significantly to current knowledge of groundwater occurrence and movement on NTS, and thus on the fate of potential grourdwater contaminants.

During testing of aquifers perforated by these wells, non-contaminated water would be discharged to local surface drainages. Maximum discharge is expected to be less than $30 \mathrm{l} / \mathrm{sec}$ (475 gpm), with a duration of 24 to 72 hours. This discharge might lead to minor local erosion during the test period and would add water to the near-surface unsaturated zone. The total volume of water to be pumped is expected to be relatively small. Water that is radioactively contaminated beyond applicable standards would be discharged, as a matter of comity, to holding tanks of at least $40 \mathrm{~m}^{3}$ $(10,500 \mathrm{gal})$ and disposed of in accordance with NVO-325, NTS Defense Waste Acceptance Criteria, Certification, and Transfer Requirements.

Radioactive contaminated water would not be released to the local environment at the GCP well sites. NTS drilling systems are equipped with radiation alarms which monitor returning fluids. Any radiation in excess of applicable standards would trigger the alarm immediately. Produced material which is contaminated would be treated by evaporating the liquid and disposing of the remaining sludge at the Area 5 low-level waste disposal site.

Hydrologic pumping effects are relatively insignificant in terms of the hydrologic regime because of their relatively low volumes and short duration. Based on the hydrogeologic data in Table 3-5, an assumed range of storage coefficients, a maximum discharge rate of $30 \mathrm{l} / \mathrm{sec}$ (475 $\mathrm{gpm}$ ) and a duration of two days, drawdowns were calculated on the basis of the Theis Equation. This mathematical model has serious limitations in its applicability to this hydrogeologic environment, particularly the fracture/solution nature of the permeability in the volcanics/carbonates, and the degree to which saturated units are confined. Despite the inherent limitations and questions of applicability, drawdowns have been calculated for two different radii from the pumped wells as 
shown in Table 4-9. The worst case condition at $3,000 \mathrm{~m}(9,843 \mathrm{ft})$ is $0.16 \mathrm{~m}(0.5 \mathrm{ft})$ drawdown. At $300 \mathrm{~m}$ (984 ft), the worst case is $39 \mathrm{~m}$ ( $128 \mathrm{ft}$ ) drawdown. Both conditions are for the welded tuff aquifer. A significant consideration in viewing the calculated drawdowns for the lower values of transmissivity in each unit is that it is highly unlikely that $30 \mathrm{l} / \mathrm{sec}(475 \mathrm{gpm})$ could be produced from those wells. A more likely discharge would be on the order of $3 \mathrm{l} / \mathrm{sec}$ (48 $\mathrm{gpm}$ ), resulting in about one-tenth the calculated drawdown. Thus, beyond the immediate vicinity of the wells (within $300 \mathrm{~m}$ [984 ft]), the drawdowns would be small and only transitory in nature.

Tracejector and constant rate/constant pressure injection tests are also anticipated. No tests would involve placing radioisotopes in the well. The constant rate/constant pressure tests would involve placing water in the borehole, but again there would be essentially no residual effects beyond the initial hydraulic response. The hydraulic response would be restricted to the immediate vicinity of the well bore, and thus is not expected to affect either water supply wells or springs. Water for these tests would come from NTS supply wells and would not present any contamination potential for the tested zones.

TABLE 4-9 ESTIMATED DRAWDOWNS (s) (m) FOR TWO RADII IN THE CARBONATE, WELDED TUFF, AND ALLUVIAL AQUIFERS FOR BOUNDING RANGES OF TRANSMISSIVITY (T) AND STORAGE COEFFICIENTS (S).

\section{Carbonate Aquifer}

\begin{tabular}{cc|c|c|c|c|c}
\multicolumn{3}{c|}{$\mathrm{T}^{(1)}=7 \mathrm{~m}^{2} / \mathrm{d}$} & \multicolumn{3}{c|}{$\mathrm{T}=10,000 \mathrm{~m}^{2} / \mathrm{d}$} \\
\cline { 2 - 6 } $\mathrm{r}(\mathrm{m})$ & $\mathrm{S}=10^{-2}$ & $\mathrm{~S}=10^{-3}$ & $S=10^{-4}$ & $S=10^{-2}$ & $S=10^{-3}$ & $S=10^{-4}$ \\
\hline $300^{(2)} 0.01$ & 5.3 & 23 & 0.03 & 0.05 & 0.06 \\
3000 & $<2 \times 10^{-5}$ & $<2 \times 10^{-5}$ & $<0.01$ & $<10^{-3}$ & 0.02 & 0.03
\end{tabular}

Weided Tuff Aquifer

\begin{tabular}{rl|c|c|c|c|c} 
& \multicolumn{3}{c|}{$\mathrm{T}=2.5 \mathrm{~m}^{2} / \mathrm{d}$} & \multicolumn{3}{c}{$\mathrm{T}=1.240 \mathrm{~m}^{2} / \mathrm{d}$} \\
\cline { 2 - 7 } $\mathrm{r}(\mathrm{m})$ & $\mathrm{S}=10^{-1}$ & $\mathrm{~S}=10^{-3}$ & $\mathrm{~S}=10^{-4}$ & $\mathrm{~S}=10^{-1}$ & $\mathrm{~S}=10^{-3}$ & $\mathrm{~S}=10^{-4}$ \\
\hline 300 & $<10^{-5}$ & 3.5 & 39 & 0.05 & 0.28 & 0.4 \\
3000 & $<10^{-5}$ & $<10^{-5}$ & $<0.01$ & $<10^{-7}$ & 0.05 & 0.16
\end{tabular}

\section{Alluvial Aquifer}

\begin{tabular}{rl|c|c|c|c|c} 
& \multicolumn{3}{c|}{$\mathrm{T}=10 \mathrm{~m}^{2} / \mathrm{d}$} & \multicolumn{3}{c}{$\mathrm{T}=420 \mathrm{~m}^{2} / \mathrm{d}$} \\
\cline { 2 - 7 }$r(\mathrm{~m})$ & $\mathrm{S}=10^{-1}$ & $\mathrm{~S}=10^{-2}$ & $\mathrm{~S}=10^{-3}$ & $\mathrm{~S}=10^{-1}$ & $\mathrm{~S}=10^{-2}$ & $\mathrm{~S}=10^{-3}$ \\
\hline 300 & $<10^{-5}$ & 0.05 & 5.1 & 0.05 & 0.31 & 0.67 \\
3000 & $<10^{-5}$ & $<10^{-5}$ & $<0.01$ & $<10^{-7}$ & $<10^{-7}$ & 0.05 \\
\hline
\end{tabular}

$$
\mathrm{Q}=30 \mathrm{l} / \mathrm{sec}, \quad \mathrm{t}=2 \text { days, } \quad \mathrm{s}=\frac{\mathrm{Q}}{4 \Pi \mathrm{T}} \mathrm{w}(\mathrm{u}), \quad \mathrm{u}=\frac{\mathrm{r}^{2} \mathrm{~S}}{4 \mathrm{~T} t}
$$

(1) $\mathrm{T}\left[\mathrm{m}^{2} / \mathrm{d}\right] \times 80.94=\mathrm{T}[\mathrm{gpd} / \mathrm{ft}]$

(2) $\mathrm{m} \times 3.281=\mathrm{ft}$ 
Because of the proposed air foam drilling technique (see Appendix A), water consumption during drilling would be limited. The major water use would be for dust control on the pads and access roads. This consumption, while relatively large, would be only a small part of total NTS water use and is not expected to adversely affect the water supply system or the pumped aquifers.

\subsection{BIOLOGICAL RESOURCES}

\subsubsection{Vegetation}

The four sample GCP well sites are located in the desert shrub communities of the Great Basin and transition deserts of NTS. Of the 100 sites proposed for the GCP, it is likely that wells would eventually be located in all of the major vegetation associations. All well sites would be purposefully located away from vegetation associations considered unique or sensitive. At worst preparation of the 100 well sites would result in the loss of approximately $40 \mathrm{ha}(100 \mathrm{ac})$ of native vegetation, and access road improvement would result in the loss of approximately 730 additional hectares $(1,800 \mathrm{ac})$. Some well sites would be located in areas of previous disturbance. Attempts would be made to utilize existing roads wherever possible. Development and use of borrow areas in some locations may also result in vegetation clearing. The total area of disturbance by the GCP within any given vegetation type would be small in comparison to the total acreage occupied by that particular vegetation type in the region. Therefore, clearing activities are considered to constitute only a minor adverse effect. Reclamation activities would further reduce the long-term effect on vegetation. Overall activities associated with the GCP are not anticipated to have a substantial impact on the native vegetation associations of the NTS.

Certain plant species (e.g., cacti, Joshua trees, other yucca species), while not protected under the ESA, are protected under NRS 527: Protection of Christmas Trees, Cacti and Yucca. The letter and intent of this law is geared towards protecting these species from illegal collection for commercial resale or private use. Nevertheless, efforts are made during preactivity surveys of sensitive species to identify and flag individual cacti and yucca. Efforts would then be made during construction, to the extent practicable, to avoid or relocate significant populations of cacti and yucca.

\subsubsection{Wildlife}

As described in Section 4.6.1, preparation of each well site would result in some loss of native vegetation. The very limited amount of clearing that would be necessary for this program is not expected to result in significant effects on local wildlife populations, although there would be some localized habitat disturbance or destruction.

Well site preparation would require the presence of personnel and equipment in relatively remote areas of the NTS over a period of approximately three months per site. Wildlife populations and habitats may undergo local impacts from construction activities. Impacts would tend to be 
greatest on small ground-dwelling animals that live underground. Large mammals may be temporarily disturbed by construction activities. Overall effects from human presence would be of short duration and unlikely to have major effects on local wildlife populations.

Standard DOE drilling procedures would not result in the release of toxic materials to the environment. Releases of radioactivity to the surface or subsurface environment would not occur because if radioactive materials are encountered during the drilling process, all such materials and fluids would be diverted to holding tanks. All materials brought to the surface would be carefully monitored during the drilling process.

Wildlife species not listed as threatened or endangered under the ESA are not legally protected from Federal construction activities. However, during preactivity sensitive species surveys, distinctive habitat features (e.g., badger or coyote burrows) would be mapped and described in the report. Efforts would then be made during construction, to the extent practicable, to avoid these habitat features, relocate the wildlife, or take other preventative measures to protect wildlife individuals.

\subsubsection{Sensitive Species}

The four sample GCP sites are each located in potential habitat for one or more of the sensitive plant species present on NTS. Sensitive plant species occur on the NTS in areas where habitat characteristics are suitable for growth and survival. Rarity of these species is attributable to the specific microsite conditions under which survival is possible. While such characteristics may occur in specific areas throughout the region, they do not occur continuously across the landscape. Despite a species' propensity for rareness, any one species may occur in many locations throughout its range.

Although candidate species are not formally protected under the ESA, DOE policy specifies that preactivity surveys be performed on all construction sites in the event that these species may become listed in the future. Each survey includes 100 percent coverage of a staked project area, plus a suitable buffer area, the size of which is dependent on the proposed activity. Locations of all sensitive plant habitats are flagged in the field and the associated report of results includes map locations and recommendations for protection. Preactivity survey procedures are described in more detail in Appendix B In the case of Beatley's astragalus, the only C1 plant species, guidance for its protection was contained in a DOE conservation agreement with the USFWS (1988). This agreement, which expired on December 23, 1991, called for DOE to study the effects of its activities on the species. DOE has conducted this study and expects to report the results to USFWS formally in late 1992. Based on a review of the draft report, DOE activities have had no effect on Beatley's astragalus.

Depending on location, GCP wells may be located within the habitat of some of the sensitive plant species known to occur on the NTS. DOE policy is to conduct preactivity surveys at all project sites to determine if populations of these plant species occur or would be affected. In the unlikely 
event that sensitive plant populations are found at a GCP site, every effort would be made to protect individual plants or habitat through site relocation.

The endangered peregrine falcon, and candidate raptor and shorebird species are unlikely to occur on the NTS. Therefore, effects on these species as a result of the GCP are not expected.

The sample GCP sites analyzed for this assessment are not located in the habitat of the threatened desert tortoise. However, future sites would be located in the Mojave Desert portion of the NTS which contains tortoise habitat. An estimated $20 \mathrm{GCP}$ wells would be so located.

With the mitigation measures anticipated to be implemented as a result of consultation with the USFWS through the ESA Section 7 process, the possibility of direct mortality would be minimal, though not nonexistent. There would likely be some loss of habitat due to road and drill pad construction which would, in most cases, avoid important habitat features such as burrows, pallets. and drinking depressions. No critical habitat has been identified in southern Nevada by the USFWS. Any such designation would probably be placed on tortoise habitat occurring farther south than the NTS, which is located on the northern fringes of desert tortoise habitat. Since no critical habitat is involved and since mitigation would reduce or avoid the effects on key habitat features, there would not be a significant effect on habitat.

In May 1992, a Biological Opinion was obtained from the USFWS, which concluded that DOE activities on the NTS, including the proposed GCP, would not likely threaten the continued existence of the desert tortoise (USFWS, 1992).

\subsection{HISTORICAL AND CULTURAL RESOURCES}

Previous archaeological and historical research on the NTS, as well as the cultural resource surveys conducted at the four example characterization well sites (Section 3.7), indicate that historic properties eligible for nomination to the National Register of Historic Places may occur on lands proposed for the development of characterization wells. The construction of characterization wells would have a potential to adversely affect those historic properties located in, and around, the areas selected for these wells. On the mesas, where a Programmatic Agreement between the DOE, the Nevada State Historic Preservation Officer, and the National Advisory Council on Historic Preservation is in effect, data recovery would be undertaken if GCP activities would disturb areas which have been identified as sample units. In all areas of the mesas, the PA requires that surveys be conducted to identify historic resources that may be affected by the project. In all other portions of the NTS, preactivity surveys would be conducted and consultation with the SHPO completed prior to any surface-disturbing activities. At off-NTS locations, preactivity surveys would be undertaken and SHPO consultation would be completed in coordination with the BLM. SHPO consultations may result in the need for data recovery, a decision for avoidance, or a decision that the resources are not significant. Appropriate measures would be taken to mitigate any potential effects at identified historic properties. A plan for conducting these preactivity surveys and alternative 
measures for mitigating any potential adverse effects is presented in Appendix C. In most cases, DOE expects that the drill site or road alignment could be moved to avoid impacting significant historical or cultural resources. Further, no action would occur until consultations with SHPO and NACHP are completed and all actions would be subject to the agreements reached. For these reasons, substantial adverse impacts on historical and cultural resources are unlikely.

\subsection{VISUAL RESOURCES}

Impacts on visual resources may include intermittent visual interruption of the natural open expanses of land caused by well pads and road construction. In general, road segments are short and well casings would not protrude into the skyline. The nature of the project action should not result in extersive loss of integrity of visual resources in natural areas.

\subsection{SOCIOECONOMICS}

The total budget for the GCP over the next 5 to 10 years is estimated to be approximately $\$ 21$ million per year, or only about 1 percent the DOEANV operating budget. Because the GCP is only a small part of the DOE/NV program, it is difficult to separate out identifiable socioeconomic effects of that program. Further, it is uncertain to what extent the GCP activities would represent new activities and additional personnel versus re-programming of existing personnel and funds. Undoubtedly, some of both would occur.

The GCP is not expected to have any adverse socioeconomic effects. The funds expended on this effort would add to the economic health of the region. Any new personnel associated with this activity would not adversely affect housing, schools or other aspects of the region. Those individuals would be expected to live in the Las Vegas area, which is currently experiencing rapid economic growth in other sectors.

\subsection{OCCUPATIONAL HAZARDS, NOISE AND WORKER SAFETY}

Drilling and road construction activities on the NTS are addressed in Standard Operating Procedures Manuals that provide guidelines for safe equipment operation. All NTS contractor employees are required to follow these guidelines and attend periodic safety courses. Provided that these guidelines are followed, the risk of equipment operator injury would be minimized.

Previous radiation surveys have identified those areas of the NTS in which surface contamination exceeds levels safe for unrestricted access by site personnel. These areas have been signed or roped off for identification. While unlikely, if a drill site had to be located in an area of high surface contamination, the site would be cleared up by crews equipped with radiation protection, thus no risk of exposure by drilling or GCP personnel to resuspended on-site radioactive particulates would be anticipated. During drilling operations, there would be a limited risk of contact or 
proximity exposure to radioactively contaminated materials produced from downhole. There would be continuous monitoring of drilling fluid returns and formation water for radiation levels. Periodic sampling for tritium would detect trends in tritium content. Elevated tritium is expected to be the first sign of contamination, by either radioactive or hazardous material because of its mobility as compared to other contaminants. Tritium would be expected at low levels initially, trending upwards slowly in advance of heavier contamination. Any fluids that exceed EPA drinking water standards for radioactivity would be diverted to holding tanks for containment until disposed of in accordance with DOE/NV procedures. This methodology would preclude exposures to hazardous materials. Any potential exposures to radiation are expected to be within DOE/NV health standards (see Appendix D). All personnel on the NTS wear radiation badges that are evaluated at least quarterly, or upon suspected radiation exposure.

The NTS operating procedures and the proposed drilling/testing plan should preclude adverse worker safety problems.

Noise levels are high during these operations, but workers are required to wear hearing protection and there are no nearby residents who might be affected.

\subsection{CUMULATIVE IMPACTS}

Cumulative impacts are the impacts on the environment which result from the incremental impact(s) of the action when added to other past, present, and reasonably foreseeable future actions. The following discussion focuses on the cumulative effects of the GCP on the existing resources when considered with all ongoing and past DOE programs on the NTS. Overall impacts are summarized in Table 4-10.

NTS has been and continues to be the location of a variety of activities related to the development and testing of nuclear weapons. Programs conducted on the NTS have typically required large labor forces. Present-day NTS programs employ 4,000 to 5,000 personnel. A variety of facilities are operated and maintained in support of NTS personnel, including the Mercury and Area 12 complexes, the Desert Rock Airstrip, sewage treatment facilities, sanitary landfills, and water distribution projects.

There are approximately $650 \mathrm{~km}$ (404 mi) of primary paved roads on the NTS, of which approximately $320 \mathrm{~km}$ (199 $\mathrm{mi}$ ) are travelled regularly. Road maintenance, as well as power and communication line maintenance are ongoing activities on the NTS.

Major ongoing programs on the NTS include nuclear weapons testing, and various Environmental Restoration Program activities, including the GCP. Facilities associated with each of these major programs are concentrated in small areas throughout the NTS.

The overall area of disturbance for the GCP (approximately 770 ha [1,900 ac] of drill pads, sumps, roads, and borrow pits) is small (approximately 0.1 percent) compared to the overall land 
TABLE 4-10 SUMMARY OF OVERALL IMPACTS OF THE GROUNDWATER CHARACTERIZATION PROJECT.

\begin{tabular}{|c|c|}
\hline Resource & Cumulative Effect \\
\hline Topography/Physiography & Localized disturbance of up to $770 \mathrm{ha}(1,900 \mathrm{ac})$. \\
\hline Climate/Meteorology & No effect. \\
\hline Air Quality & No violations of ambient air quality standards likely. \\
\hline Geology/Minerals & $\begin{array}{l}\text { No adverse effects; may provide new knowledge of } \\
\text { regional geology. }\end{array}$ \\
\hline Hydrology/Water Resources & $\begin{array}{l}\text { No effect on regional hydrologic regime, springs or } \\
\text { water supply. }\end{array}$ \\
\hline Vegetation & $\begin{array}{l}\text { Localized disturbance of up to } 770 \mathrm{ha}(1,900 \mathrm{ac}) \text { of } \\
\text { vegetation; no widespread effect anticipated. }\end{array}$ \\
\hline Wildlife & $\begin{array}{l}\text { Localized disturbance of up to } 770 \mathrm{ha}(1,900 \mathrm{ac}) \text { of } \\
\text { wildlife habitat; no widespread effect anticipated. }\end{array}$ \\
\hline Sensitive Species & $\begin{array}{l}\text { Desert tortoise: some well sites (approximately } 154 \text { ha } \\
\text { [380 ac]) could eventually be located in desert tortoise } \\
\text { habitat. }\end{array}$ \\
\hline & $\begin{array}{l}\text { - Sensitive plant species: some well sites (up to } 770 \text { ha } \\
\text { [1,900 ac]) would be located in sensitive plant habitat: } \\
\text { plants would be protected to the extent possible through } \\
\text { site relocation to avoid disturbance, or through } \\
\text { transplanting where practicable. }\end{array}$ \\
\hline Historic/Cultural Resources & $\begin{array}{l}\text { Some well sites (up to } 770 \text { ha }[1,900 \text { ac]) may coincide } \\
\text { with cultural/historic resource sites; sites would be } \\
\text { protected to the extent possible through preactivity } \\
\text { surveys. }\end{array}$ \\
\hline - & $\begin{array}{l}\text { - American Indian Religious Freedom Act (AIRFA): } \\
\text { consultations with Native Americans on religious sites } \\
\text { outside of Yucca Mountain and Weapons Program } \\
\text { AIRFA areas would be conducted, as appropriate, in } \\
\text { accordance with DOE policy. }\end{array}$ \\
\hline Visual Resources & $\begin{array}{l}\text { No extensive effect on visual resource integrity } \\
\text { expected. }\end{array}$ \\
\hline Socioeconomics & $\begin{array}{l}\text { No adverse effects; funds expended would contribute to } \\
\text { regional economic health. }\end{array}$ \\
\hline $\begin{array}{l}\text { Occupational Hazards/Noise/ } \\
\text { Worker Safety }\end{array}$ & $\begin{array}{l}\text { No effect; DOE Standard Operating Procedures in } \\
\text { place. }\end{array}$ \\
\hline
\end{tabular}


area of the NTS $(329,628 \mathrm{ha}[814,528 \mathrm{ac}])$, and is small in comparison to past and present-day land disturbances. The GCP sites would be distributed throughout the NTS in order to obtain the required data for groundwater flow characterization. Disturbance at any one site would be small and localized.

Cumulative impacts on air resources are not expected to be significant. All existing NTS facilities are presently in compliance with their air emission permits. Emission sources for NTS activities are distributed over a large area, which assists in the dispersion of air pollutants released to the environment.

Cumulative adverse impacts on geologic, hydrologic, and soil resources are not expected as a result of the GCP.

Cumulative impacts as a result of the GCP on biological resources, including vegetation, wildlife and sensitive species, are expected to be minor. Approximately 20 wells could eventually be located in desert tortoise habitat. The BA, which includes all NTS activities for the period FY91 through FY95, concludes that while a few desert tortoises may be accidentally killed, or some habitat destroyed, NTS programs (including the GCP) will not threaten the continued existence of the species either on NTS or throughout its range (DOE, 1991). The USFWS issued a "no jeopardy" opinion in May 1992 (USFWS, 1992).

Cumulative impacts on sensitive plant species are also expected to be minor. Preactivity surveys are conducted for all NTS activities and efforts are made to avoid destruction of individual plants, populations or habitats, where technically feasible. In some cases, plants or habitats may be destroyed if there is no practical alternative to project implementation. However, the probability of these types of occurrences is low. It is concluded that the GCP will not threaten the continued existence of any of these species either on NTS or throughout their overall range.

Cumulative impacts on cultural resources would be minor. Since 1978, a comprehensive program of preactivity surveys, avoidance of cultural resources, and data recovery projects has been conducted. This program insures protection and preservation of cultural resources prior to all disturbance.

Cumulative impacts on visual resources, occupational hazards, noise levels, and worker safety and health are considered minor.

Cumulative impacts on socioeconomics resulting from the GCP are regarded as minor because the program would directly contribute only 1 percent of the entire NTS operating budget. In conclusion, all impacts would be mitigated to the extent possible. 


\subsection{REFERENCES}

ACGIH, 1986. Threshold Limit Values and Biological Exposure Indices for 1986-1987. American Conference of Governmental Industrial Hygienists, 6500 Glenway Ave., Bldg. D-7. Cincinnati, Ohio 45211-4438, ISBN 0-936712-69-4.

Barker, J.P., 1990. Cultural Resources Inventory Guidelines, Fourth Edition. U.S. Bureau of Land Management, Nevada State Office.

Barnes, H., E.B. Ekren, C.L. Rodgers and D.C. Hedlund, 1982. Geologic and Tectonic Maps of the Mercury Quadrangle, Nye and Clark Counties, Nevada. U.S. Geological Survey, Miscellaneous Geologic Investigations, Map I-1197.

Barnes, H., F.N. Houser and F.G. Poole, 1963. Geologic Map of the Oak Spring Quadrangle, Nye County, Nevada. U.S. Geological Survey, Map GQ-214.

Beatley, J.C., 1976. Vascular Plants of the Nevada Test Site and Central-Southern Nevada: Ecologic and Geographic Distributions. Laboratory of Nuclear Medicine and Radiation Biology, University of California, Los Angeles, TID-26881.

Bergin, K.A., C.S. Crownover, C. Stevens, R. Stockton, S. Vaughan, D. Jenkins, R. Brooks, D. Ferraro, A. Turner, L. Kirkberg, P. Olson, R. Maus, G. Stough, R. Scheuch and G. Tullis, 1979. Final Report on the 1978 Archaeological Investigations of the Nellis Air Force Bombing and Gunnery Ranges, Nye, Lincoln and Clark Counties, Nevada. Archaeological Research Center, Museum of Natural History, University of Nevada, Las Vegas.

Bergin, K.A. and R. Roske, 1978. Literature Overview Concerning Cultural Resources of the Nellis Bombing and Gunnery Ranges, Nye, Lincoln and Clark Counties, Nevada. Unpublished report, Archaeological Research Center, Museum of Natural History, University of Nevada, Las Vegas.

BLM (U.S. Bureau of Land Management), 1989. Draft Resource Plan and Environmental Impact Statement for the Nellis Air Force Range Planning Area. Las Vegas, Nevada.

Burbey, T.J. and S.W. Wheatcraft, 1986. Tritium and Chlorine-36 Migration from a Nuclear Explosion Cavity. Desert Research Institute, Water Resources Center Report No. 45050.

Byres, F.M., Jr., C.L. Rogers, W.J. Carr and S.J. Luft, 1966. Geologic Map of the Buckboard Mesa Quadrangle, Nye County, Nevada. U.S. Geological Survey, Map GQ-552.

Byres, F.M., Jr. and H. Barnes, 1967. Geologic Map of the Pahute Ridge Quadrangle, Nye and Lincoln Counties, Nevada. U.S. Geological Survey, Map GQ-577.

Carr, W.J. and W.D. Quinlivan, 1966. Geologic Map of the Timber Mountain Quadrangle, Nye County, Nevada. U.S. Geological Survey, Map GQ-503.

Claassen. H.C., 1973. Water Quality and Physical Characteristics of Nevada Test Site WaterSupply Wells, USGS Pub. \#USGS-474-158; NTS \#NTS-242. 
Cochrane, S., 1979. Status of Endangered and Threatened Plant Species on Nevada Test Site -- A Survey, Parts 1 and 2. Appendix C: Collection records for the taxa considered. EGG 1183-2356, S-646-R.

Colton, R.B. and E.J. Mckay, 1966. Geologic Map of the Yucca Flat Quadrangle, Nye and Lincoln Counties, Nevada. U.S. Geological Survey, Map GQ-582.

Cullen, J. and C. Russell, 1990. Groundwater Monitoring Program - Draft. Desert Research Institute, Water Resources Center, Las Vegas, Nevada.

DOE (U.S. Department of Energy), 1988a. Environment, Safety and Health, Office of Environmental Audit. Environmental Survey Preliminary Report, Nevada Test Site, Mercury, Nevada.

DOE (U.S. Department of Energy), 1988b. RCRA Part B Permit Application Mixed Waste Management Facility, Nevada Test Site, Mercury, Nevada. Vol. I, Vol. II and Vol. II Exhibits.

DOE (U.S. Department of Energy), 1989. Order DOE 5480.11, Radiation Protection for Occupational Workers, July 20, 1989.

DOE (U.S. Department of Energy), 1991. Biological Assessment of the Effects of Activities of the U.S. Department of Energy Field Office, Nevada on the Threatened Desert Tortoise. Las Vegas, Nevada.

EDAW, 1975. Archeology and History, Section 16. In ELF Communications Seafarer Program, Site Survey Final Report, Western Regions, Book 2, Nevada Data. Report No. 0309-B005-003, Navel Electronic Systems Command.

Ekren, E.B. and K.A. Sargent, 1965. Geologic Map of the Skull Mountain Quadrangle, Nye County, Nevada. U.S. Geological Survey, Map GQ-387.

Elliot, R.R., 1973. History of Nevada. University of Nevada Press, Reno.

EPA (U.S. Environmental Protection Agency), 1976. Radiological Quality of the Environment. Report EPA-520/1-76-010, U.S. EPA Office of Radiation Programs, NTIS.

EPA (U.S. Environmental Protection Agency), 1985. Compilation of Air Pollutant Emission Factors, Volumes 1 and 2 (4th Edition). Publication AP-42, U.S. Environmental Protection Agency, Research Triangle Park, North Carolina.

ERDA (U.S. Energy Research and Development Agency), 1977. Final Environmental Impact Statement, Nevada Test Site, Nye County, Nevada, Report No. ERDA-1551.

Fernald, A.T., G.S. Corchary and W.P. Williams, 1968. Surficial Geologic Map of Yucca Flat, Nye and Clark Counties, Nevada. U.S. Geological Survey, Miscellaneous Geologic Investigations, Map I-550. 
Gibbons, A.B., E.N. Hinrichs, W.R. Hansen and R.W. Lemke, 1963. Geology of the Rainier Mesa Quadrangle, Nye County, Nevada. U.S. Geological Survey, Map GQ-215.

Gonzales, D.A., 1986. Radiological Effluent and Jnsite Area Monitoring Report for the Nevada Test Site (January 1985 through December 1985). DOE/NV/10327-28.

Green, B., 1987. Memorandum, June 6, 1987. Department of Energy, Weapons Design and Testing Division, Washington, D.C.

Harrington, M.R., 1925. Unpublished letter dated May 7, 1925 to Governor J. G. Scrugham. File No. 44012 , Nevada Historical Society, Reno.

Henton, G.H., 1984a. A Class II Cultural Resources Reconnaissance of a Drill Pad, Skid Trails and Two Borrow Pits at U20ao, Pahute Mesa, Nye County, Nevada. Desert Research Institute Cultural Resources Reconnaissance Short Report No. 091084-1.

Henton, G.H., 1984b. A Class III Cultural Resources Reconnaissance of Drill Pad U20ak, Pahute Mesa, Nye County, Nevada. Desert Research Institute Cultural Resources Reconnaissance Short Report No. 111684-1.

Henton, G.H., 1985. A Class III Cultural Resources Reconnaissance of Drill Pad U20aq and Associated Borrow Pit, Pahute Mesa, Nye County, Nevada. Desert Research Institute Cultural Resources Reconnaissance Short Report No. 051185-1.

Hoover, P.B. and others, 1982. Electrical Studies at the Proposed Wahmonie and Calico Hills Nuclear Waste Sites, Nye County, Nevada. Open-File Report 82-466.

Hunter, R.B. and P.A. Medica, 1987. Status of the Flora and Fauna on the Nevada Test Site in 1987 -- Results of continuing basic environmental research, January through December 1987. DOE/NV/10630-2.

IMACS, 1989. Intermountain Antiquities Computer System User's Guide. University of Utah, Bureau of Land Management, U.S. Forest Service.

Livingston, S.D., 1988. A Class III Cultural Resource Reconnaissance of the U.S.G.S.'s Drill Site HRMP\#3, Access Road and Proposed Borrow Pit, Nye County, Nevada. Desert Research Institute Cultural Resources Reconnaissance Short Report No. 062688-1.

Long, M, 1950. The Shadow of the Arrow. Caxton Printers.

Maldonado, F., 1985. Geologic Map of the Jackass Flats Area, Nye County, Nevada. U.S. Geological Survey, Miscellaneous Geologic Investigations, Map I-1519.

McKay, E.J. and W.P. Williams, 1964. Geology of the Jackass Flats Quadrangle, Nye County, Nevada. U.S. Geological Survey, Map GQ-368.

McKeown, F.A., D.L. Healey and C.H. Miller, 1976. Geologic Map of the Yucca Lake Quadrangle, Nye County, Nevada. U.S. Geological Survey, Map GQ-1327. 
McLane, A.R., 1988a. A Class III Cultural Resources Reconnaissance of Drill Hole U20bc. Desert Research Institute Cultural Resources Reconnaissance Short Report No. 021088-1.

McLane, A.R., 1988b. A Class III Cultural Resources Reconnaissance of the G Tunnel Area. Desert Research Institute Cultural Resources Reconnaissance Short Report No. 060988-2.

NCRP, 1971. Basic Radiation Protection Criteria. National Council on Radiation Protection. NCRP Publications, Washington, D.C.

O'Farrell T.P. and E. Collins, 1984. Surveys for Astragalus beatleyae on Nellis Bombing Range, Nye County, Nevada.

O'Farrell T.P. and L.A. Emery, 1976. Ecology of the Nevada Test Site: A Narrative Summary and Annotated Bibliography. Applied Ecology and Physiology Center, Desert Research Institute, Boulder City, Nevada.

Orkild, P.P., 1963. Geologic Map of the Tippipah Spring Quadrangle, Nye County, Nevada. U.S. Geological Survey, Map GQ-213.

Orkild, P.P., K.A. Sargent and R.P. Snyder, 1969. Geologic Map of Pahute Mesa, Nevada Test Site and Vicinity, Nye County, Nevada. U.S. Geological Survey, Miscellaneous Geologic Investigations, Map I-567.

Patton, E.P., M.G. Novo and J.H. Shinn, 1986. Environmental Assessment of the LGF Spill Test Facility at Frenchman Flat, Nevada Test Site, U.S. DOE, DOE/EA 3009.

Pippin, L.C., 1984. Limited Test Excavations at Selected Archaeological Sites in the NNWSI Yucca Mountain Project Area, Southern Nye County, Nevada. Desert Research Institute, Social Sciences Center Technical Report No. 40. ISBN 0-945920-40-7.

Pippin, L.C., 1986. An Overview of Cultural Resources on Pahute and Rainier Mesas on the Nevada Test Site, Nye County, Nevada. Desert Research Institute, Social Sciences Center Technical Report No. 45.

Pippin, L.C., A.R. McLane and G.H. Henton, 1987. A Class II Archaeological Reconnaissance of a Portion of Area 20, Nevada Test Site, Nye County, Nevada. Desert Research Institure, Social Sciences Center Technical Report No. 52.

Pippin, L. and G. Henton, 1990. Long Range Study Plan for Negating Potential Adverse Effects to Cultural Resources on Pahute and Rainier Mesas, Nevada Test Site, Nevada. Unpublished Manuscript.

Pitchford, M., R.G. Flocchini, R.G. Draftz, T.A. Cahill, L.L. Ashbaugh and R.A. Eldred, 1981. Silicon in Submicron Particles in the Southwest. Atmos. Environ., 15, pp. 321-334.

Poole, F.G., D.P. Elston and W.J. Carr, 1965. Geologic Map of the Cane Spring Quadrangle, Nye County, Nevada. U.S. Geological Survey, Map GQ-455. 
Poole, F.G., 1965. Geologic Map of the Frenchman Flat Quadrangle, Nye, Lincoln, and Clark Counties, Nevada. U.S. Geological Survey, Map GQ-456.

Quade, J. and J.V. Tingley, 1984. A Mineral Inventory of the Nevada Test Site and Portions of Nellis Bombing and Gunnery Range, Southern Nye County, Nevada. Nevada Bureau of Mines and Geology Open-File Report 84-2.

Quiring, R.F., 1968. Climatological Data, Nevada Test Site and Nuclear Rocket Development Station. U.S. Department of Commerce, Environmental Sciences and Services Administration Report ERLTM-ARL 7.

Reno, R.L., 1982a. Archaeological Reconnaissance of a 1500' Radius Around Drill Pad U20al, the Skid Trail Connecting the Pad to the Pahute Mesa Road, and the Enlargement of an Existing Borrow Pit. Desert Research Institute Cultural Resources Reconnaissance Short Report No. 061082-1.

Reno, R.L., 1982b. Class III Cultural Resources Reconnaissance of a Pad and Support Areas for Drill Hole UYcw. Desert Research Institute Cultural Resources Reconnaissance Short Report No. 092082-1.

Reno, R.L., 1984. A Class III Cultural Resources Reconnaissance of the Direct Bury Fiber Optic Line between Area 12 Camp and N Tunnel, Nevada Test Site, Nye County, Nevada. Desert Research Institute Cultural Resources Reconnaissance Short Report No. 052184-1.

Reno, R.L., 1986a. A Class III Cultural Resources Reconnaissance of Drill Pad U20at, Pahute Mesa, Nye County, Nevada. Desert Research Institute Cultural Resources Reconnaissance Short Report No. 010886-1.

Reno, R.L., 1986b. A Class III Cultural Resources Reconnaissance of a Proposed Borrow Pit (Location \#2) at U20at, Pahute Mesa, Nye County, Nevada. Desert Research Institute Cultural Resources Reconnaissance Short Report No. 011686-1.

Reno, R.L., 1986c. A Class III Cultural Resources Reconnaissance of a Proposed Borrow Pit (Location \#1) at U20at, Pahute Mesa, Nye County, Nevada. Desert Research Institute Cultural Resources Reconnaissance Short Report No. 011686-2.

Reno, R.L., 1987. A Class III Cultural Resources Reconnaissance of Drill Pad U20bb, Pahute Mesa, Nye County, Nevada. Desert Research Institute Cultural Resources Reconnaissance Short Report No. 111487-1.

Reno, R.L. and L.C. Pippin, 1985. An Archaeological Reconnaissance of Yucca Flat, Nye County, Nevada. Desert Research Institute, Social Sciences Center Technical Report No. 35.

Sargent, K.A. and P.P. Orkild, 1973. Geologic Map of the Wheelbarrow Peak-Rainier Mesa Area, Nye County, Nevada. U.S. Geological Survey, Miscellaneous Geologic Investigations, Map I-550. 
Shinn, J.H. and R.T. Cederwall, 1981. Selecting Optimum Periods for Atmospheric Dispersion Tests Over Water Surfaces at Frenchman Flat, Nevada Test Site. Lawrence Livermore National Laboratory, Livermore, California, UCD-18907.

Shutler, R., Jr., 1961. Lost City, Pueblo Grande de Nevada. Nevada State Museum Anthropological Papers 5.

Stoffle, R., D. Halmo, J. Olmsted, M. Evans, 1990. Native American Cultural Resources Studies at Yucca Mountain, Nevada. Institute for Social Research. The University of Michigan, Ann Arbor.

USFWS (U.S. Fish and Wildlife Service), 1988. Conservation Agreement (for Astragalus beatleyae). USFWS Great Basin Complex Office, Reno, NV and DOE/NV Operations Office, Las Vegas, NV, December.

USFWS (U.S. Fish and Wildlife Service), 1992. Biological Opinion on Nevada Test Site Activities. USFWS Reno Field Office, File No. 1-5-91-F-225.

Waddell, R.K., J.H. Robison and R.K. Blankennagel, 1984. Hydrology of Yucca Mountain and Vicinity, Nevada--Califomia: Investigative Results Through Mid-1983. U.S. Geological Survey, Water-Resources Investigations Report 84-4267, 35 pp.

Wheeler, S.M., 1940. The Archeology of Etna Cave, Lincoln County, Nevada. Desert Research Institute Publications in the Social Sciences 7, Edited by D. D. Fowler and A. Smith, 1973.

Winograd, IJ. and W. Thordarson, 1975. Hydrogeologic and Hydrochemical Framework, SouthCentral Great Basin, Nevada-California, With Special Reference to the Nevada Test Site. U.S. Geological Survey, Professional Paper 712-C, 119 pp.

Worman, F.C.V., 1964. Anatomy of the Nevada Test Site. University of California, Los Alamos Scientific Laboratory Report.

Worman, F.C.V., 1966. The Current Status of Archeology at the Nevada Test Site and Nuclear Rocket Development Station. Los Alamos Scientific Laboratory Report LA-3520-MS.

Worman, F.C.V., 1967. Nevada Test Site Archeology. Nevada Archaeological Survey Reporter 1(2): 5-6.

Worman, F.C.V., 1969. Archaeological Investigations at the U.S. Atomic Energy Commission's Nevada Test Site and Nuclear Rocket Development Station. University of California, Los Alamos Scientific Laboratory Report LA4125. 


\subsection{PREPARERS}

Dr. Gilbert F. Cochran was responsible for the overall coordination, management and preparation of the EA, and analysis of geological and water resources. He holds a Ph.D. in Hydrology and has 18 years of experience in various areas of research and administration related to all aspects of water resources and other environmental concerns. Dr. Cochran is a Research Professor with the Water Resources Center of the Desert Research Institute, University of Nevada System.

Ms. Janet M. Jackson was responsible for the overall preparation of the EA and analyses of biological resources. She holds an M.S. in Botany and has 9 years of experience in ecological studies of arid zone ecosystems. Ms. Jackson is a Plant Ecologist with the Biological Sciences Center of the Desert Research Institute. University of Nevada System.

Mr. Daniel Freeman was responsible for examining air quality impacts and related aspects for the EA. He holds an M.S. in Meteorology and has 10 years experience in evaluation of air quality and meteorological monitoring. Mr. Freeman is an Associate Research Meteorologist with the Energy and Environmental Engineering Center of the Desert Research Institute, University of Nevada System.

Mr. Greg Henton was responsible for the overall cultural resource survey and evaluation. He holds an M.A. in Anthropology and has 20 years of experience in the Great Basin region and California. Mr. Henton is an Archaeologist with the Quaternary Sciences Center of the Desert Research Institute. University of Nevada System.

Ms. Patricia Hicks was responsible for conducting the cultural resource preactivity surveys for the program. She holds an M.A. in Anthropology and has 16 years of experience in research in the Great Basin region. Ms. Hicks is an Archaeologist with the Quaternary Sciences Center of the Desert Research Institute, University of Nevada System. 


\subsection{OTHER AGENCIES AND ORGANIZATIONS CONSULTED}

Defense Nuclear Agency

Earth Technology Corporation

EG\&G Energy Measurements

Lawrence Livermore National Laboratory

Los Alamos National Laboratory

Raytheon Services Nevada

Reynolds Electrical and Engineering Co., Inc.

State of Nevada

Department of Administration

Department of Wildlife

Division of Environmental Protection

Division of Historic Preservation and Archaeology

Division of Water Resources

U.S. Air Force/Department of Energy Liaison Office 


\section{APPENDIX A}

\section{Design Concepts and Construction of the Characterization Wells}


This appendix describes the technical concepts and construction details for wells planned to be drilled by DOE for the Groundwater Characterization Project. Certain procedures may be revised for future wells based on these drilling activities.

\section{A1.0 PREACTIVITY ACTIVITIES}

Archaeological and environmental surveys would be completed in accordance with standard NTS procedures prior to the start of any drilling related activities. Approval of survey resuls by DRI, EG\&G, and Nevada Test Site Operations (NTSO) must be received prior to any site construction.

\section{A2.0 SITE PREPARATION}

The approximate location of the well was staked on March 9, 1990. This location may be moved, not more than 100 feet in any direction, to facilitate siting of the drill pad. Relocation to distances greater than 100 feet would require DRI and EG\&G review. NTSO's permission must be received prior to moving the rig on site.

REECo Drilling must notify Environmental Sciences prior to commencing work on the site for purposes of radiological monitoring. All current NTS safety procedures, including radiological procedures, would be strictly adhered to.

NTSO would notify the driller of its decisions regarding the methods by which water and electric utilities would be made available. It is expected that water would need to be hauled to the drill site and that generators would be required to supply electric power. It would be necessary to construct a short entry road to the drill pad. The pad area would be cleared to a size that would promote safe working practice and would be leveled. A lined sump pit would be constructed to minimize infiltration losses of fluids. No chemicals which are on the EPA RCRA list of hazardous materials would be permitted to enter the pit.

\section{A3.0 DRILLING REQUIREMENTS}

\section{A3.1 SETTING THE SURFACE CASING}

It is expected that a large diameter (20-inch O.D. or greater) surface casing would be used. The casing would be set to a competent casing point. Casing depth is expected to be a minimum of 50 feet, but may be as deep as 120 feet. The driller would run and set casing of a diameter and wall thickness (schedule) of his choice, consistent with NTS practice. To insure verticality of the casing. the borehole must be sufficiently large so as to permit the surface casing to hang free prior to cementing. The casing would be cemented to the surface.

\section{A3.2 DRILLING THROUGH THE UNSATURATED ZONE TO THE WATER TABLE}

Drilling above the water table would be accomplished through the use of reverse or direct airfoam rotary drilling techniques. Standard hole size will be approximately $171 / 2$-inch in diameter. 
Drilling shall continue until the Chief Scientist determines, with the advice of the driller, that the water table has been reached. Appropriate stabilization techniques shall be used to insure that the hole is as vertically plumb as possible.

It is likely that perched water would be encountered in some wells. Care must be given to insuring that drilling continues to the actual water table. It is recognized that determining the position of the water table is somewhat of a judgment call and may require stopping and restarting of the drilling operations several times.

All field practices shall be designed to minimize the amount of water which is required to remove cuttings. LiBr would be used as a tracer for identifying drilling fluids. Volumes of water used are to be recorded as a function of drilling depth. Well site geology services are to be provided by Raytheon Services of Nevada (RSN) geologists. Flowline (cuttings) samples would be taken, identified, bagged, labeled, and archived, in accordance with standard NTS practice, at 10-foot intervals. Penetration rates and pressures would be recorded. Cores may be taken above the water table.

Once the water table has been reached, drilling shall continue for between 50 and 100 feet. At this point the well would be conditioned and water levels would be permitted to stabilize overnight. A water level would be tagged as part of the dry geophysical logging program.

\section{A3.3 LOG UNSATURATED HOLE}

Specific geophysical logs run in the unsaturated portion of the hole may include:

\section{Caliper Log}

Fluid Density Log

Compensated Density Log

Dual Induction Log

Spectral Gamma Ray Log

Epithermal Neutron Porosity Log

Total Magnetic Intensity Log

Gyroscopic Survey Log

Camera Log

Caliper logs are used to determine the variability of the borehole diameter. Fluid density logs are used in the unsaturated zone primarily as a means of determining the static water level. Borehole compensated density logs give an indication of rock density, compensated for the effect of the varying diameter of the borehole on the logging tool. The induction and gamma ray logs are used to detect lithologic variations. The epithermal neutron porosity log provides an indication of rock porosity. The total magnetic intensity $\log$ is sensitive to small changes in the remnant magnetism of the rock and is used to detect minor changes in lithology. The gyro survey log measures the 
deviation from verticality of the borehole as a function of depth. The camera log is used to obtain a visual record of the borehole for geologic interpretation and construction activities.

Logs would be run from the current bottom of the hole to the bottom of the surface casing. All logs would be correlated as to depth and shall be recorded on magnetic tape. Paper copies of the logs shall be provided at a scale of 1 inch $=50$ feet and 1 inch $=20$ feet, as per standard practice, and delivered to DRI at the time they are made.

\section{A3.4 CASE UNSATURATED HOLE}

After completing the dry hole geophysical logs, the hole would be cased. The driller would run a tube as a grout line to within 10 feet of the desired setting depth for the casing. The tubing string is to be landed to the side of the hole and then the casing is to be run. The diameter of the intermediate casing would be small enough to ensure an adequate cement job and large enough to provide room for all future tests, planned completions, and contingent completions if borehole conditions degrade. A reentry shoe is required in the bottom of the string. The depth of the casing would be the measured static water level on the day the casing is run unless otherwise directed by DRI's drilling engineer. Any casing materials set below the water level would be constructed of either Type 304L or Type 316L stainless steel.

The entire annular region surrounding the casing would be cemented. Standard practice of cementing the bottom 200 feet of the casing would not be employed because of the potential for increasing the rates of vertical migration of groundwater in the vicinity of the wellbore. The ciriller may, at his discretion and in accordance with standard practice, cement the casing in stages.

\section{A3.5 DRILL OR CORE TO TOTAL SATURATED DEPTH}

Drilling would continue through the grout plug and beneath the water table to a total depth to be determined by the Chief Scientist. This depth is expected to average 5,500 feet and may be as deep as 6,000 feet, depending on the locations of various lithologic contacts and geologic structures. Hole diameter will be determined on a hole-to-hole basis. Good field practice and appropriate bottom-hole assemblies are to be used to promote verticality of the hole. DRI would specify the use of $\mathrm{LiBr}$ as a tracer to identify drilling fluids. Volumes of water used are to be recorded as a function of drilling depth. Well site geology service is to be provided by RSN geologists. Flowline (cuttings) samples would be taken, identified, bagged, labeled, and archived, in accordance with RSN and USGS procedures, at 10-foot intervals and penetration rates and pressures would be recorded.

The drilling program may be interrupted for the purpose of coring. The Chief Scientist would specify the exact locations from which the cores are to be taken. Requested core lengths and diame-

ters are to be determined by the Chief Scientist on a hole-by-hole basis. Core lengths may vary from single 30-foot cores to thousands of feet of continuous wireline cores. 
All fluid returns are to be monitored continuously for chemical content. In the event that tritium concentrations are measured to be in excess of EPA Safe Drinking Water Act standards $(20,000 \mathrm{pCi} / \mathrm{L})$, drilling would be stopped. Drilling of the hole would not be recommenced until such time as DOE/NV has an approved policy and procedures for handling and disposal of radioactively contaminated drilling fluids and water.

After drilling has been completed, the hole would be conditioned prior to running any geophysical logs. The drilling rig would be demobilized at this point and a service rig (workover rig) would be sited at the hole.

\section{A3.6 LOG SATURATED HOLE}

Specific geophysical logs to be run in the saturated portion of the hole would include:

Caliper Log

Fluid Density Log

Compensated Density Log

Temperature Log

Dual Laterolog

Spectral Gamma Ray Log

Epithermal Neutron Porosity Log

Oxygen Activation Log

Total Magnetic Intensity Log

Acoustic Televiewer Log

Gravity Meter Log

Gyroscopic Survey Log

Pulse Thermal Flow Log

Seismic Airgun

Formation Microscanner

\section{A4.0 HYDRAULIC TESTING PROGRAM}

\section{A4.1 OPEN HOLE PREPARATION}

Prior to hydraulic testing, the open borehole would be developed to remove cuttings, drilling fluids, and other materials that may affect the quality of the planned test, especially if polymers of bentonite muds are used to drill the borehole. Initially, a small diameter tubing would be lowered into the borehole and used to airlift viscous material out of the borehole. Deflocullants such as sodium tetraphosphate or chlorine bleach may be used to aid in the breakdown and removal of drilling materials. Once the turbidity of the discharging fluid has dropped to 100 NTU or less, air, or air-foam solely, would be used to drill the well, then a pump would be lowered into the well. The 
pump would be alternately tumed on and off to surge the well and remove the resulting fluids. Purging should continue until turbidity is below 5 NTU and bromide concentrations are approximately 3 ppm.

\section{A4.2 OPEN HOLE HYDRAULIC TESTS}

Open hole hydraulic tests would be performed on some of the earlier wells to be drilled under the GCP. The results of these tests would be compared to the results of tests to be conducted in the completed wells. If the two testing methods produce results that are essentially similar, then it may be possible to eliminate open hole hydraulic tests in future wells.

The purpose of these tests is to determine the transmissivity of various stratigraphic units that are encountered in the well. Transmissivity is a measure of the resistance of the rock unit to the flow of groundwater -- the higher the transmissivity, the more easily the groundwater can pass through the aquifer. Other terms, such as permeability, hydraulic conductivity and coefficient of transmissibility, have been used to describe the same property as transmissivity. Recently, hydrogeologists have refined their use of these terms to indicate slightly different quantities.

Three different tests would be used to measure the transmissivity of the hydrostratigraphic unit in an open hole. The reason that three different tests are used is that they act as checks against one another to make sure that the mechanics of the tests are being executed properly. Specific examples on how these checks work are described below.

\section{A4.2.1 Open Hole Multiple Rate Test}

A standard multiple rate (step-crawdown type) test would be conducted to determine the well's efficiency, specific capacity, formation loss, and well loss in preparation for one or more long-term tests. Flow rates would be designed to bracket flowline test yields reported by the driller but may be changed by the Chief Scientist during execution of the test, depending on his ongoing evaluation of the data. A minimum of six one-hour steps would be used, assuming that the well would support the desired yields. One day would be dedicated to executing this test.

Standard DRI procedures would be used to size and set the pump. The pump suction would be set at approximately 100 feet below the static water level. A monitoring string would be attached and/or landed to the bottom of the pump motor at the discretion of REECo Site Maintenance Water Section.

\section{A4.2.2 Open Hole Tracejector Survey}

Following the multiple rate test, an oxygen activation log would be run. The Chief Scientist would, in conjunction with the drillers, determine specific intervals to be tested, based on the results of the flowline tests. One day would be dedicated to executing this test. 


\section{A4.2.3 Open Hole Converging Aquifer Test}

Following analysis of the multiple rate test and tracejector test, a standard pump test would be run in the open hole. Pumping rate would be determined from the results of the multiple rate test. The test would be run for a minimum of 24 hours and may be run as long as 72 hours. The pump and monitor tubing would be pulled at the conclusion of this test. Three days would be scheduled for this test.

\section{A4.3 PACKER TESTS}

\section{A4.3.1 Constant Rate Injection Test}

In a constant rate injection test, water is pumped into a packed-off interval in the wellbore at a constant rate of flow and the pressure required to maintain that constant flow rate is measured with time. Characteristically, the pressure of the injected fluid would increase with time, but the rate of that pressure increase would decrease with time. The Chief Scientist would determine the desired flow rates and the ranges of the expected pressure buildups. Flow rates are to be monitored with a calibrated turbine meter or some alternate device which gives a reliable indication of flow rate versus time. Downhole pressures are to be recorded with two pressure transducers.

The test would be conducted in a step-wise fashion with either three or four flow-rate increases. Ideally, at a given point in time after each flow-rate increase, the pressure in the well should build up in direct proportion to the increase in flow rate. If this does not occur, it is an indication of either a poor packer seating or short-circuiting of the packers through the surrounding rock fractures. Data collected includes the buildup of pressure as a function of time for each flow rate. These data can be reduced to calculate a value of the formation's transmissivity.

\section{A4.3.2 Constant Pressure Injection Test}

A constant pressure injection test is similar to a constant flow-rate injection test except that pressures are held constant instead of flow rates. As the test continues, flow rates decrease with time at a constant pressure. As before, the test is conducted in a step-wise fashion, with three or four pressure increases. During each step, flow rates are measured as a function of time for each pressure increase. These data provide an independent means of verifying the calculated value of transmissivity for specific formations.

\section{A4.3.3 Pulse Test}

In a pulse test, a short pressure transient is introduced into the packed-off interval and its decay is measured as a function of time. The magnitude of the transient is usually on the order of 30 
to $50 \mathrm{psi}$ above hydrostatic. The duration of the transient depends on the transmissivity of the unit. It is desirable to have the transient last for several minutes, to perhaps as much as one hour, so that the shape of the decay curve can be easily defined.

Transients that last for only a few seconds (highly transmissive units) are difficult to quantify. For this reason, the pulse test is a preferred method for relatively tight units. Its drawback is that the calculated value of transmissivity is representative for only a small portion of the aquifer surrounding the wellbore.

\section{A4.3.4 General Comments on the Packer Tests}

Care must be taken to insure that the pressures in the tested intervals do not rise more than the lithohydrostatic pressure of the unit being tested in order to avoid damaging the unit. This means that unless some form of downhole pressure regulation is available, standing columns of water in the piezometers should not be raised more than 100 to 200 feet above the static water level.

All three types of packer tests may be executed at a given horizon before the packers are reset. The Chief Scientist may decide to eliminate one or more tests, depending on his examination of the results of previous tests. One day would be dedicated to each test: therefore, three days would be available to test a given horizon. Five horizons would be tested, making 15 days the entire time available for the packer tests.

\section{A4.4 RECORDING AND ANALYSIS OF DATA}

All hydrologic tests would be conducted by subcontractors and the resultant data would be transmitted to DRI in both paper copy and on magnetic media (ASCI format, $5^{1 / 4}$-inch, 360K IBM PC-XT compatible format). Data would be presented as pressure or drawdown versus time. No analyses of the data are required; DRI staff members would perform this work. DRI shall also be provided with calibration data for all transducers and downhole pressure recorders. A written log of all testing procedures shall be transmitted with the test data. The completeness and accuracy of the written log cannot be overemphasized.

\section{A5.0 WELL COMPLETION}

The design described herein represents the end result of a series of meetings conducted by DOE Environmental Restoration Branch (ERB) and Nevada Test Site Office, in conjunction with representatives of the University of Nevada's DRI, the Las Vegas office of the USGS Water Resources Division and RSN. The purpose of the meetings was to explore the advantages and disadvantages of a number of different designs for well completion structures proposed for use on the GCP. Hydrogeologists, geologists, drilling engineers, and project managers participated in the meeting. Thus, the chosen design is believed to represent a good compromise between all parties with an interest in constructing and using the wells. 
Although the wells are designated as Characterization Wells, they have been designed under the assumption that a certain proportion of them would be "converted" into monitoring wells at some future date, pending approval of a formal NTS Groundwater Monitoring Plan by the EPA. In many instances, it may be desirable to install additional completion structures into a well to facilitate water sampling. The characterization wells are designed so that no known preclusion exists to using any of the wells for purposes of groundwater monitoring.

\section{A5.1 HOLE DESIGN}

Figure A1 presents one possible design for the wells. A 30 -inch diameter hole is drilled to set a surface casing. Depths for this initial hole are expected to range between 50 and 120 feet. Standard practice is to drill to 120 feet so that a long surface casing can be set: longer casings are preferred as an aid in establishing the verticality of the hole for subsequent drilling. Once the hole is drilled, a 20-inch carbon steel surface casing would be set to the depth of the hole and cemented in place.

Drilling would continue through the surface casing with a $171 / 2$-inch bit until the water table is reached. When the depth of drilling approaches within a certain distance of the water table, as specified in a drilling plan for each hole, drilling would be suspended at each joint of pipe (or, at the discretion of DOE/ERB, at every other joint) for the purpose of attempting to locate the position of the water table. If 20 -foot joints are used, drilling would probably be suspended at every other joint: if 30 or 40 -foot joints are used, drilling would probably be suspended at each joint. Once the water table has been located, drilling would proceed for approximately 50 additional feet, at the request of RSN's logging engineers, to accommodate the length of tandem logging tools. The drill string would be removed from the hole and geophysical logs would be run in the dry portion of the hole. Then, a $13^{3} / 8$-inch intermediate casing would be set and cemented in place. The casing would be landed on the bottom of the hole with a reentry shoe so that drilling may continue through the cement plug at the bottom of the hole.

After the cement on the intermediate casing has set, the hole would be reentered and drilled to total depth with a $12^{1} / 4$-inch bit. Total depth is expected to average about 4,000 feet. Drilling may be interrupted any number of times for the purpose of obtaining core samples, as specified either in the drilling plan or in the field by the Chief Scientist. Once total depth has been reached, the drill string would be removed and both geophysical logs and open-hole hydraulic tests would be run in the saturated portion of the hole. The hydraulic tests would be limited to an examination of the hydraulic characteristics of only the most permeable hydrostratigraphic units. This approach is being taken to minimize the amount of time that the hole is left open, during which interaquifer flow via the borehole would occur. Intermediate permeability hydrostratigraphic units would be tested through the completion string. Following completion of the open hole tests, a completion assembly would be installed in the well. Additional hydraulic tests may be run in the completed hole if so directed by DOE/ERB. 


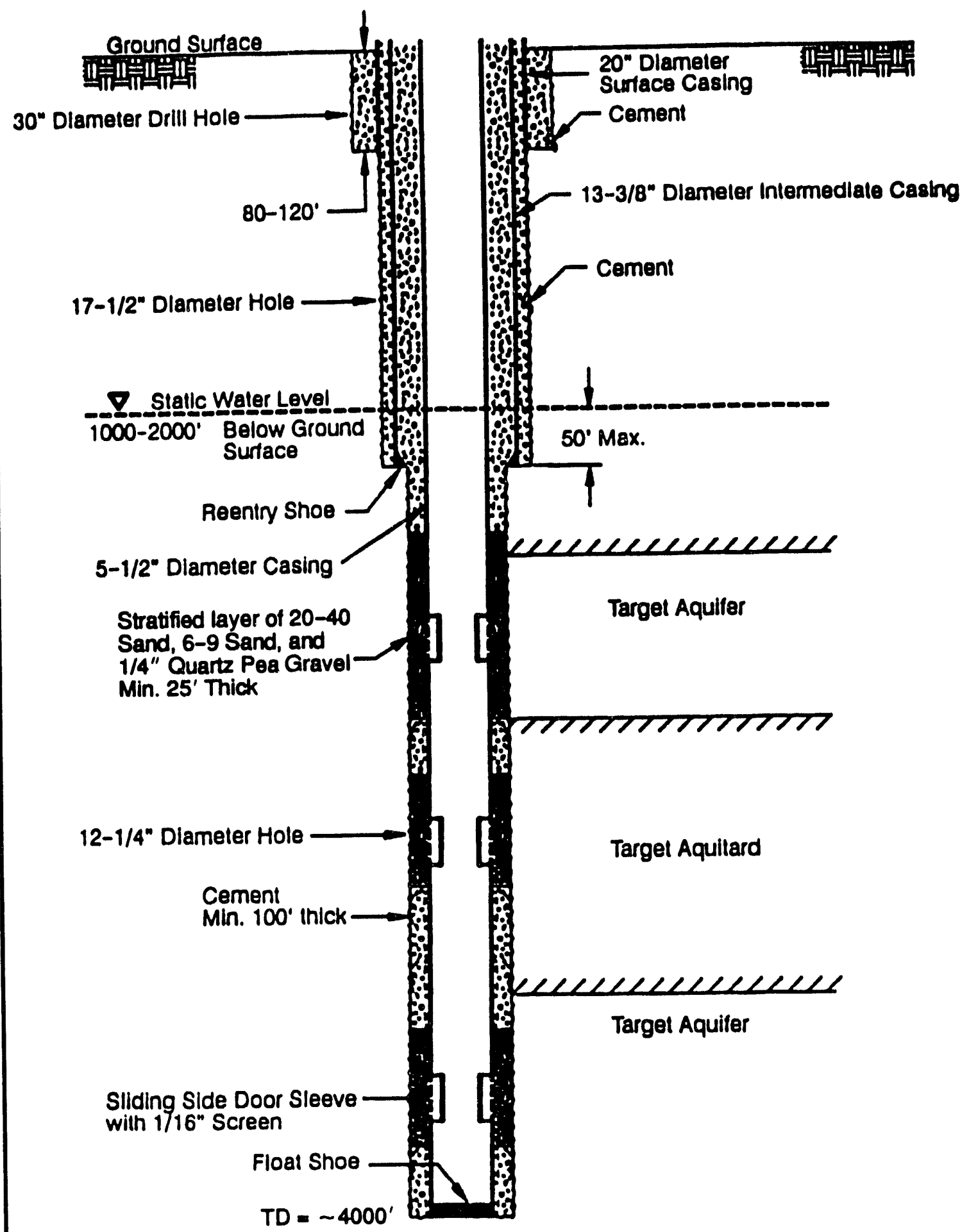

FIGURE A.1 Screened Sliding Sleeves on Inner Casing String. 


\section{A5.2 COMPLETION STRING DESIGN}

The inner casing or completion string would most likely be constructed with stainless steel from ground surface to total depth. An appropriate isolator would be installed to prevent galvanic corrosion between the dissimilar metals. The stainless portion of the casing is to be $51 / 2$-inch nominal size, with internal/external flush threads. Sliding side-door sleeves would be installed at horizons of hydrogeologic interest, in order to obtain water samples, pressure measurements, and to perform hydraulic tests on low to intermediate permeability materials. Twenty-foot long sections of 6-inch casing would be cut by an outside vendor to form slotted-pipe style well screens. The screens would be centered on and placed over the sliding side-door sleeves and would be welded to the $51 / 2$-inch casing full round on both ends. A float shoe would be installed on the bottom of the completion string to permit the entry of water as the casing is lowered into the hole.

\section{A5.3 STEMMING DESIGN}

Following installation of the completion string, a sequence of materials would be tremmied into the annular region surrounding the inner casing, to isolate one hydrostratigraphic unit from another. The sequence of materials depicted in Figure A.1 is schematic. Gravel, possibly \#4-8 or possibly 1/4-inch quartz pea gravel would be placed in the vicinity of each sliding side-door sleeve. The length of the gravel pack would be at least 20 feet, to match the length of the slotted well screen, and possibly longer if so required by the drilling engineers, to ensure an adequately thick section. $A$ smaller grain-sized sand pack (6-9 and 20-40 sand) may be placed on either side of the pea gravel to prevent intrusion of cement into the gravel pack. A 50-foot plug of cement would be placed on top of the 20-40 sand and allowed to harden prior to the staging of the remainder of the cement. The stemming sequence would be repeated for each zone of interest.

\section{A6.0 HYDROCHEMICAL TESTING REQUIREMENTS}

Following well completion, it is expected that numerous water samples would be obtained from the completed intervals. In this regard, it would be necessary to purge the well a given number of well volumes prior to taking the sample. In light of the depth to the sampling intervals, it is expected that purging rates of 25 to 50 gallons per minute would be required to keep the duration of the sampling event to a reasonable time period.

Water samples would be drawn in accordance with standard EPA procedures at the direction of the Chief Scientist. Chain-of-custody records would be kept to track sample movement. LANL and DRI would be responsible for radioisotope analysis. Standard water chemistry analyses would be performed by REECo and DRI laboratories in accordance with EPA specifications. 


\section{APPENDIX B}

\section{Sensitive Species Preactivity Survey Plan for GCP Well Sites}




\section{B1.0 SENSITIVE SPECIES PREACTIVITY SURVEY PLAN FOR GCP WELL SITES}

Preactivity surveys are required by DOENV (DOE Order 54XC.1A) for compliance with the Endangered Species Act. The order also requires that actions be taken to protect sensitive species and their critical habitat identified during the survey process. DOE conducts preactivity surveys, takes mitigation measures, and otherwise complies with the Act for proposed NTS activities.

DOE conducts surveys for sensitive species prior to any activity associated with land disturbance that may cause plants, animals, or biological resources to be destroyed, removed, killed, or threatened. The goal of the survey process is to identify candidate, proposed, threatened, or endangered plant and animal species that may be affected by land-disturbing activities onNTS, and to take all necessary actions to protect these sensitive species and their critical habitat. Projects which include surveys as part of the planning process include, but are not necessarily limited to. road construction, drill pads, stockpiled soil, storage areas, material source pits, and brush disposal sites.

\section{B2.0 SURVEY PROCESS}

Prior to conducting preactivity surveys, background references are reviewed for information on sensitive species that may occur in the proposed activity area. Plant collection records, previous survey results, and the pertinent literature are examined regarding the location of the nearest populations of sensitive species.

The area is surveyed by walking closely-spaced parallel transects inside the marked boundaries and through a buffer zone around it. The buffer zone around the proposed activity area is surveyed to allow for possible changes in layout of activity, errors in estimating surface disturbance associated with the activity or for collection of tortoise presence data needed to make prudent mitigation recommendations. Under some circumstances, a U.S. Fish and Wildlife Service recommended zone-of-influence transect around the proposed activity area is surveyed instead of a buffer zone. Nearby areas that appear to be likely habitat for important species are also examined (e.g., caliche or rock outcrops for tortoise burrows).

If sensitive species and habitats, or other important biological resources are found, the immediate area is clearly flagged, and those locations are demarcated on a field map as accurately as possible. All tortoise burrows or predator burrows which can be used by a tortoise are visually checked for occupancy. If a desert tortoise is found, it is measured and marked with a unique number. It may also be fitted with a radio transmitter if there is a possibility that the tortoise will be affected by the proposed activity and should be monitored before, during, and after the activity. All biologists who conduct surveys within the geographic range of the desert tortoise are trained and authorized by both state and federal handling permits to handle, measure, mark, and monitor tortoises. 


\section{B3.0 MITIGATION RECOMMENDATIONS}

A survey report is prepared which includes locations of the surveyed areas, the findings, and recommendations for mitigation. Mitigation recommendations are made with the intent of protecting important species or biological resources found during the surveys. Possible recommendations include the following:

1. No-action (i.e., no mitigation), if important species or important biological resources are not found.

2. Avoidance of importance species or resources by altering the design of the disturbance, altering the manner in which the activity is conducted; monitoring sensitive species during the construction process, or engaging additional precautions.

3. Informal or formal consultation with USFWS, if the area is in tortoise habitat.

4. Relocation of the proposed activity if avoidance does not protect desert tortoises.

5. Relocation of desert tortoises if the proposed activity cannot be moved to a new location. Important plant species may also be relocated under appropriate circumstances.

Preactivity survey data are effective in identifying and mitigating the possible direct effects of a proposed disturbance on local animal and plant populations. These data may also be combined with other data from NTS field studies of desert tortoise or sensitive plant species, for evaluation of the cumulative and indirect effects of NTS activities on all sensitive species and critical habitat. These data may also be used in the development of species management plans for the NTS. 


\section{APPENDIX C}

\section{Archaeological Preactivity Survey Plan for GCP Well Sites}




\section{ARCHAEOLOGICAL PREACTIVITY SURVEY PLAN FOR GCP WELLS}

The procedures for conducting archaeological preactivity surveys for the characterization wells and their access roads would vary depending on where these projects are located. If they occur in, or pass through, the area of the Pahute and Rainier Mesas Long Range Study Plan (LRSP) and avoid the currently selected sample units (Pippin and Henton, 1990), these preactivity surveys would not need to identify historic properties eligible for nomination to the National Register under criterion d of 36 CFR 60.4 since any potential effects to those properties are currently being mitigated through the LRSP. However, surveys would be required for the identification of any historic property eligible for the National Register under criterion a-c of 36 CFR 60.4. If the areas selected for the construction of the characterization wells or their access roads coincide with any of the previously selected sample units for the LRSP, then archaeological investigations for the entire area of the sample unit, including archaeological surveys, collections and investigations, must be completed prior to any ground disturbance within the sample unit. If the wells or access roads are located in or pass through Management Stratum A, as defined in the Archaeological Reconnaissance of Yucca Flat ${ }^{1}$ (1985: 155-157), then preactivity surveys are not required for the portions of the projects which fall within Stratum A. Otherwise, preactivity surveys of all pads and access roads would be required.

If a preactivity survey is required prior to field work, archaeological site records of the appropriate land managing agency would be consulted for information on previous archaeological surveys and recorded sites on or near the projects. For DOE administered lands, these would be the site inventory files maintained for the DOE at the DRI in Reno. For BLM administered lands, these would be the files at the appropriate BLM district office. For Air Force administered lands, these would be BLM district office files or Air Force records. Also, prior to the inspection, the project area must be adequately identified in the field by GCP surveyors.

Preactivity surveys for archaeological sites would conform to BLM requirements for Class III archaeological surveys (Barker, 1990: 7-10). The intent of a Class III reconnaissance is to discover all archaeological sites within the project area. This requires a systematic inspection of the area, looking for surface indications of archaeological sites. For non-linear projects, this is usually performed by archaeologists walking in parallel transects back and forth over the project area. The spacing between these transects is to be no greater than 100 feet. For linear areas, such as access roads, one or more transects would be walked parallel to the center line of the alignment. The number of transects walked and displacement from the center line would depend on the width of the disturbance, but transects would not be greater than 100 feet apart.

\footnotetext{
1 This document has not been approved by the SHPO. Until that approval is obtained, any field activities must be preceded by an anchaeological preactivity survey and appropriate consultation with the SHPO prior to any surface disturbance. Once SHPO approval of the reconnaissance document has been obtained. then the procedures detailed herein would be followed.
} 
Any sites found would be recorded on DRI site inventory forms, and the final forms for these sites would be prepared in standard Intermountain Antiquities Computer System (IMACS) hardcopy output using the NVACS software. Permanent site numbers for the sites found would be obtained from the Harry Reid Center for Environmental Studies of the University of Nevada, Las Vegas.

Finally, the results of the archaeological surveys would be reported in DRI Cultural Resource Reconnaissance Short Reports, which would describe the project area, the methods used for the inspection, the results, evaluate the significance of the sites found, and make recommendations to the DOE concerning the cultural resources found. If no National Register quality sites are found, then the project can proceed as planned. In the case where DRI evaluates archaeological sites found at a project to be National Register quality, and if the DOE concurs, the DOE submits this recommendation to the ACHP and the NDHPA for their concurrence. At this time, DOE has the option of abandoning the project, modifying it so as to not adversely impact the significant cultural resources, or to mitigate the impacts by archaeological investigations. Should the DOE choose the latter course, then the DOE would direct the DRI to prepare a data recovery plan for the affected sites; and if the DOE concurs with the plan, submit it to the ACHP and NDHPA. With ACHP and NDHPA approval, data recovery can begin; and when the field work is completed, the project implemented. 


\section{APPENDIX D}

\section{DOE/NV Radiation Exposure Standards}




\section{DOE/NV RADIATION EXPOSURE STANDARDS}

The following material has been extracted from Chapter IV of the DOE/NV Radiological Safety Manual (Report No. NV 54XG.1A, October 21, 1991). The chapter contains additional material with respect to ALARA programs and committees, exposures for minors and special exposures, and contractor requirements. The material not reproduced is basically of an administrative nature.

\section{CHAPTER IV \\ RADIATION EXPOSURE LIMITS}

1. PURPOSE. This chapter summarizes the occupational and nonoccupational radiation exposure limits that have been established by DOE Order 5480.11 , and sets forth administrative guidelines for workers at the NTS and other DOE/NV facilities.

2. SCOPE. This procedure is applicable to DOE/NV and all DOE/NV contractors, subcontractors, and user organizations of the NTS or other DOENV facilities.

3. POLICY. All operations under DOE/NV's purview shall be performed in a manner that ensures worker exposure to radiation is maintained as far below the occupational exposure limits as is reasonably achievable.

4. AS LOW AS REASONABLY ACHIEVABLE (ALARA)

a. ALARA Programs. Each organization must implement documented ALARA programs of their own which clearly demonstrate their awareness and commitment to the ALARA policy. These ALARA programs should conform to the guidelines defined in Pacific Northwest Laboratory-6577, Health Physics Manual of Good Practices for Reducing Exposure Levels That Are as Low as Reasonably Achievable.

$\bullet$

$\bullet$

5. DOEANV OCCUPATIONAL EXPOSURE LIMTTS

a. Exposure Limits for Radiation Workers. The maximum permissible exposure standards for occupational workers are set forth in DOE Order 5480.11 and are implemented at DOE/NV facilities by NV Order 5480.11 (see Figure IV-1).

b. Note that several things have changed: quarterly limits are no longer used, the concept of annual effective dose equivalents has been adopted from International Commission 


\begin{tabular}{|c|c|}
\hline Whole-Body Exposure & $\begin{array}{l}5 \text { rem (annual effective dose } \\
\text { equivalent--external }+ \text { internal) }\end{array}$ \\
\hline Lens of Eye & 15 rem (annual dose equivalent) \\
\hline Extremity Exposure & 50 rem (annual dose equivalent) \\
\hline Skin of Whole Body & 50 rem (annual dose equivalent) \\
\hline Organ or Tissue & 50 rem (annual dose equivalent) \\
\hline $\begin{array}{l}\text { Unborn Child } \\
\text { Entire Gestational Period }\end{array}$ & 0.5 rem (annual dose equivalent) \\
\hline
\end{tabular}

Figure IV-1

Radiation Protection and Measurements 30, and a dose limit has been set for the unborn child of a female worker who has notified her employer in writing that she is pregnant.

c. Exposure Limits for General Site Workers (GSW).

(1) DOE/NV has established administrative exposure guidelines for GSWs who are not provided radiation worker training (see Chapter III). Radiation exposure to GSWs is administratively controlled to levels allowed for the public entering a controlled area (DOE Order 5480.11). These limits are 0.100 rem for whole body, 1.5 rem for the lens of the eye, and 5 rem for extremities, skin, or other tissue.

(2) It is the responsibility of each organization to ensure that their GSWs' exposures are maintained below these administrative limits. If a GSW receives an exposure that exceeds these limits, the employing organization must report the nature of the exposure to HPD. The information shall be reported in the format specified for unusual occurrence reports (UOR) (DOE and NV Orders 5000.3), but shall not be considered a UOR.

d. Additional Guidelines. DOE/NV contractors/users may impose administrative guidelines for radiation workers exposures that are below those specified by DOE and NV Orders 5480.11. Administrative guides are used to ensure that the possible error between dose estimates and the exposures indicated by approved radiation dosimeters do not result in annual effective dose equivalents exceeding the DOE and DOE/NV limits. 


\section{SPECIAL SITUATIONS}

b. Unborn Child. DOE and NV Orders 5480.11 established a dose limit of 0.5 rem for the unborn child of a female RW who has notified her employer in writing that she is pregnant. A female worker who is pregnant, or who suspects she is pregnant, should notify her employer. Upon notification, the employer shall make every effort to limit the female worker's exposure to levels below this limit. If the worker's exposure has already exceeded $0.5 \mathrm{rem}$, then the worker should be assigned work only where additional occupational exposure is unlikely.

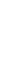

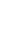




\section{APPENDIX E}

\section{Methods and Calculations for Air}

Quality Environmental Assessment 


\section{E1.0 BASIC EMISSION FACTORS}

The basic emission factors used for the GCP assessment were taken from EPA document AP-42. "Compilation of Air Pollutant Emission Factors." These are given in the following paragraphs.

\section{E1.1 PAD AND ROAD CONSTRUCTION}

For general construction, the particulate emission factor for Heavy Construction Operations (AP-42, Section 11.2.4) was used. This emission factor is:

$$
\mathrm{E}=1.2 \text { tons per acre per month of activity }
$$

This is intended for particulate matter less than $30 \mu \mathrm{m}$ in aerodynamic diameter and was used to represent TSP.

\section{E1.2 UNPAVED ROAD TRAVEL}

The particulate emission factor for unpaved road travel (AP-42, Section 11.2.1) is:

$$
E=k(9)\left(\frac{s}{12}\right)\left(\frac{S}{30}\right)\left(\frac{W}{3}\right)^{0.7}\left(\frac{w}{4}\right)^{0.5}\left(\frac{365-p}{p}\right) \frac{l b}{V M T}
$$

where VMT denotes vehicle miles traveled. Symbols used, and values assumed for this assessment, are:

$$
\begin{aligned}
& \mathbf{k}=0.8 \text { for } \mathrm{TSP} \\
& \mathbf{S}=\quad \text { silt content }=5 \text { percent } \\
& \mathbf{S}=\quad \text { mean vehicle speed }=30 \mathrm{mph} \\
& \mathbf{W}=\quad \text { mean vehicle weight }=0.75 \text { tons } \\
& \mathbf{w}=\quad \text { number of wheels }=4 \\
& \mathbf{p}=\quad \text { number of days per year with precipitation } \geq 0.1 \text { inches }=30
\end{aligned}
$$

With these symbol values, the Unpaved Road Travel emission factor is:

$$
\mathrm{E}=0.68 \mathrm{lb} / \mathrm{VMT} \text { for TSP }
$$

\section{E1.3 EQUIPMENT EXHAUST}

Emission factors were used to estimate diesel-fueled construction equipment emissions of $\mathrm{CO}$ (carbon monoxide), $\mathrm{NO}_{\mathbf{x}}$ (nitrogen oxides), $\mathrm{SO}_{\mathbf{x}}$ (sulfur oxides), and particulates, as TSP. 
These were taken from AP-42 (Section II-7, Heavy Duty Construction Equipment) and are as follows:

\section{Emission Factor \\ (lb/hour)}

\begin{tabular}{|c|c|c|c|c|c|c|}
\hline Pollutant & Dozer & Scraper & Blade & $\begin{array}{l}\text { Water } \\
\text { Truck }\end{array}$ & $\begin{array}{c}\begin{array}{c}\text { Roller/ } \\
\text { Compactor }\end{array} \\
\end{array}$ & $\begin{array}{c}\text { TOTAL } \\
\text { for Equip. } \\
\text { Mixe } \\
\end{array}$ \\
\hline $\mathrm{CO}$ & $1.794^{\circ}$ & 1.257 & 0.151 & $1.794^{a}$ & $0.151^{b}$ & 10.14 \\
\hline $\mathrm{NO}_{\mathrm{x}}$ & $4.166^{a}$ & 3.840 & 0.713 & $4.166^{\circledR}$ & $0.713^{b}$ & 26.48 \\
\hline $\mathrm{SO}_{\mathrm{x}}$ & 0.348 & 0.463 & 0.086 & $0.454^{\mathrm{a}}$ & $0.086^{b}$ & 2.79 \\
\hline TSP & 0.165 & 0.406 & 0.061 & $0.256^{\mathrm{a}}$ & $0.061^{b}$ & 1.84 \\
\hline
\end{tabular}

"As given in AP-42 for "off-highway truck"

b Same emission factor as used for blade

c Two each of dozer, scraper, blade, water truck, and one roller/compactor

\section{E1.4 DIESEL-FUELED INTERNAL COMBUSTION ENGINES}

Emission factors for various pollutants for diesel-fueled stationary sources (generators, pumps, air compressors, eic.) were as given in AP-42 (Section 3.3) for diesel engines. Brake-specific emission factors were used with rated horsepower to provide upper limit estimates, as follows:

\begin{tabular}{lc} 
Pollutant & $\begin{array}{c}\text { Emission } \\
\text { Factor } \\
\text { (g/hp-hour) }\end{array}$ \\
\cline { 2 - 2 } & 3.03 \\
$\mathrm{NO}_{x}$ & 14.0 \\
$\mathrm{SO}_{\mathrm{x}}$ & 0.931 \\
Particulates & 1.0
\end{tabular}

\section{E1.5 WIND EROSION}

The emission factor used for TSP emissions resulting from wind erosion of exposed areas is that given in AP-42 (Section 11.2.3.3) for active storage piles.

$$
E=D\left(\frac{s}{\bar{D}}\right)\left(\frac{365-p}{235}\right)\left(\frac{f}{15}\right) 1 b / \text { day/acre }
$$

Symbols, meanings, and values used are:

$s=$ silt content $=5$ percent

$p=$ number of days per year with precipitation $\geq .01$ inches $=30$

$f=$ percentage of time that unobstructed wind speed exceeds $5.4 \mathrm{~m} / \mathrm{s}(12 \mathrm{mph})=$ 30 percent, based on 5 years of data from Yucca Flat 
With these values:

$$
\mathrm{E}=16.16 \mathrm{lb} / \mathrm{day} / \mathrm{acre}
$$

\section{E2.0 TOTAL EMISSIONS DURING CONSTRUCTION}

\section{E2.1 PAD CONSTRUCTION}

Assume: 1. Pad plus sump area is 43,560 square feet $=1.0$ acres ( 0.405 hectares)

2. Watering provides 50 percent emissions reduction

3. Pad construction takes one month.

Then, for each well site:

$$
\begin{aligned}
& E_{T \alpha}=2\left(\frac{\text { tons }}{\text { acre }- \text { month }}\right) 1 \text { (month) } D \text { (acres) } \frac{50}{100}(\%) \\
& =6 \text { ton TSP }
\end{aligned}
$$

\section{E2.2 ROAD CONSTRUCTION}

Assume: 1. Road width is 40 feet and road construction rate is 2 miles/month ( 0.5 mile/ week), so that the areal road construction rate is 9.7 acres/month.

2. Water during construction provides 50 percent reduction in particulate (TSP) emissions.

Then:

$$
\mathrm{E}_{\mathrm{Tot}}=\mathrm{D}\left(\frac{\text { tons }}{\mathrm{acre}-\text { month }}\right) g \text { (acres) } \underset{\text { Time }}{\text { Construction }} \text { (months) } \frac{50}{100}(\%)
$$

\begin{tabular}{|c|c|c|c|c|}
\hline \multirow[b]{2}{*}{ Site } & \multirow{2}{*}{$\begin{array}{r}\text { Road } \\
\text { Length } \\
\text { (miles) } \\
\end{array}$} & \multirow{2}{*}{$\begin{array}{c}\text { Construction } \\
\text { Time } \\
\text { (months) } \\
\end{array}$} & \multicolumn{2}{|c|}{ Total TSP Emissions (tons) } \\
\hline & & & Uncontrolled & Controlled \\
\hline ER-19-1 & 7.5 & 3.75 & 43.7 & 21.8 \\
\hline ER-EC-2 & 4.1 & 2.05 & 23.9 & 11.9 \\
\hline ER-12-1 & 0.2 & 0.10 & 1.2 & 0.6 \\
\hline ER-9-1 & 3.6 & 1.80 & 21.0 & 10.5 \\
\hline
\end{tabular}

gives the following table of TSP emissions for road construction at each of the four GCP well sites: 


\section{E2.3 UNPAVED ROAD TRAVEL}

Assume: Four vehicle round-trips each workday, for 22 workdays during a 1-month construction period.

Then:

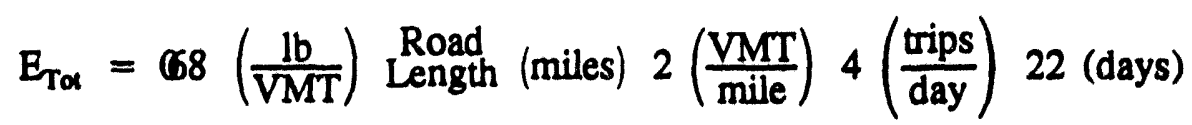

gives the following table of total TSP emissions for unpaved road travel for each site during the 1-month (22 days) construction period:

\begin{tabular}{|c|c|c|c|}
\hline \multirow[b]{2}{*}{ Site } & \multirow{2}{*}{$\begin{array}{c}\text { Road } \\
\text { Length } \\
\text { (miles) } \\
\end{array}$} & \multicolumn{2}{|c|}{ Total TSP Emission } \\
\hline & & (lb) & (tons) \\
\hline ER-19-1 & 7.5 & 898 & 0.45 \\
\hline ER-EC-2 & 4.1 & 491 & 0.25 \\
\hline ER-12-1 & 0.2 & 24 & 0.01 \\
\hline ER-9-1 & 3.6 & 431 & 0.22 \\
\hline
\end{tabular}

\section{E2.4 HEAVY EQUIPMENT EXHAUST EMISSIONS}

\section{E2.4.1 Pad Construction}

Assume: 1. Heavy equipment mix consists of 2 dozers, 2 scrapers, 2 blades, 2 water trucks, and 1 roller/compactor, so that the total emission factor for the complete mix, given in Appendix Section E1.3, is used.

2. Equipment is in use 8 hours/day for 22 days of construction period.

Then:

$$
\mathrm{E}_{\mathrm{Tot}}=\underset{\text { Factor }}{\text { Emission }}\left(\frac{\mathrm{lb}}{\text { hour }}\right) 8\left(\frac{\text { hours }}{\text { day }}\right) 22 \text { (days) } \frac{1}{2,000}\left(\frac{\text { tons }}{\mathrm{lb}}\right)
$$

\begin{tabular}{|c|c|c|c|}
\hline \multirow[b]{2}{*}{ Pollutant } & \multirow{2}{*}{$\begin{array}{c}\text { Emission } \\
\text { Factor } \\
\text { (lb/hour) }\end{array}$} & \multicolumn{2}{|c|}{ Total Emissions } \\
\hline & & (lb) & (tons) \\
\hline $\mathrm{CO}$ & 10.14 & 1,785 & 0.89 \\
\hline $\mathrm{NO}_{x}$ & 26.48 & 4,660 & 2.33 \\
\hline $\mathrm{SO}_{\mathbf{x}}$ & 2.79 & 491 & 0.25 \\
\hline TSP & 1.84 & 324 & 0.16 \\
\hline
\end{tabular}

and emission factors for $\mathrm{CO}, \mathrm{NO}_{\mathbf{x}}, \mathrm{SO}_{\mathrm{x}}$, and TSP given in Section E1.3 yield the following table: 


\section{E2.4.2 Road Construction}

Assume: 1. Same equipment mix as above.

2. Construction rate is 0.1 miles/day ( 0.5 mile/week).

Then:

$$
\mathrm{E}_{\mathrm{Ta}}=\underset{\text { Factor }}{\text { Emission }}\left(\frac{\mathrm{lb}}{\text { hour }}\right) 8\left(\frac{\text { hours }}{\text { day }}\right) \underset{\text { Time }}{\text { Construction }} \text { (days) } \frac{1}{2,000}\left(\frac{\text { tons }}{1 \mathrm{~b}}\right)
$$

and emission factors given in Section E1.3 yield the following table of emissions, by site:

\begin{tabular}{|c|c|c|c|}
\hline \multirow[b]{2}{*}{$\begin{array}{c}\text { Site/Pollutant } \\
\text { (construction time) }\end{array}$} & \multirow{2}{*}{$\begin{array}{c}\text { Emission } \\
\text { Factor } \\
\text { (lb/hour) } \\
\end{array}$} & \multicolumn{2}{|c|}{ Total Emissions } \\
\hline & & (lb) & (tons) \\
\hline $\begin{array}{l}\text { ER-19-1 (75.0 days) } \\
\text { CO } \\
\mathrm{NO}_{\mathrm{x}} \\
\mathrm{SO}_{\mathrm{x}} \\
\mathrm{TSP}\end{array}$ & $\begin{array}{r}10.14 \\
26.48 \\
2.79 \\
1.84\end{array}$ & $\begin{array}{r}6,084 \\
15,888 \\
1,674 \\
1,104\end{array}$ & $\begin{array}{l}3.04 \\
7.94 \\
0.84 \\
0.55\end{array}$ \\
\hline $\begin{array}{l}\text { ER-EC-2 (41.0 days } \\
\text { CO } \\
\mathrm{NO}_{\mathrm{x}} \\
\mathrm{SO}_{\mathrm{x}} \\
\mathrm{TSP}\end{array}$ & $\begin{array}{r}10.14 \\
26.48 \\
2.79 \\
1.84\end{array}$ & $\begin{array}{r}3,326 \\
8,686 \\
916 \\
604\end{array}$ & $\begin{array}{l}1.66 \\
4.34 \\
0.46 \\
0.30\end{array}$ \\
\hline $\begin{array}{l}\text { ER-12-1 (2.0 days) } \\
\text { CO } \\
\mathrm{NO}_{\mathrm{x}} \\
\mathrm{SO}_{\mathrm{x}} \\
\mathrm{TSP}\end{array}$ & $\begin{array}{r}10.14 \\
26.48 \\
2.79 \\
1.84\end{array}$ & $\begin{array}{r}162 \\
424 \\
44 \\
30\end{array}$ & $\begin{array}{l}0.08 \\
0.21 \\
0.02 \\
0.02\end{array}$ \\
\hline ER-9-1 (36.0 days) & & & \\
\hline $\begin{array}{l}\mathrm{CO} \\
\mathrm{NO}_{\mathrm{x}} \\
\mathrm{SO}_{\mathrm{x}} \\
\mathrm{TSP}\end{array}$ & $\begin{array}{r}10.14 \\
26.48 \\
2.79 \\
1.84\end{array}$ & $\begin{array}{r}2,920 \\
7,626 \\
804 \\
530\end{array}$ & $\begin{array}{l}1.46 \\
3.81 \\
0.40 \\
0.27\end{array}$ \\
\hline
\end{tabular}

\section{E2.4.3 Combined Heavy Equipment Exhaust Emissions}

Combining the above emissions from pad construction and road construction gives the following table of total emissions in tons:

\begin{tabular}{|c|c|c|c|c|}
\hline \multirow[b]{2}{*}{ Pollutant } & \\
\hline & ER-19-1 & ER-EC-2 & ER-12-1 & ER-9-1 \\
\hline $\mathrm{CO}$ & 3.9 & 2.5 & 0.9 & 2.3 \\
\hline $\mathrm{NO}_{\mathrm{x}}$ & 10.3 & 6.7 & 2.5 & 6.1 \\
\hline $\mathrm{SO}_{\mathrm{x}}$ & 1.1 & 0.7 & 0.3 & 0.7 \\
\hline TSP & 0.7 & 0.5 & 0.2 & 0.4 \\
\hline
\end{tabular}




\section{E2.5 WIND EROSION}

Assume: 1. Area subject to wind erosinn is 1.0 acres of pad plus sump area, plus road area according to road length.

2. Total time period of one month for pad construction.

Then:

$$
\begin{gathered}
E_{T a t}=106\left(\frac{1 b}{\text { acre }- \text { day }}\right) 30\left(\frac{\text { days }}{\text { month }}\right) 1 \text { (month) } \\
\text { Total (acres) } \frac{1}{2,000}\left(\frac{\text { tons }}{\mathrm{Ib}}\right)
\end{gathered}
$$

with total acres for each site based on road width of 40 feet gives the following table of total wind erosion TSP emissions:

\begin{tabular}{lcccc} 
Site & $\begin{array}{c}\text { Road } \\
\text { Length } \\
\text { (miles) }\end{array}$ & $\begin{array}{c}\text { Road } \\
\text { Area } \\
\text { (acres) }\end{array}$ & $\begin{array}{c}\text { Total } \\
\text { Area } \\
\text { (acres) }\end{array}$ & $\begin{array}{c}\text { TSP } \\
\text { Emissions } \\
\text { (tons) }\end{array}$ \\
\hline ER-19-1 & 7.5 & $\underline{36.36}$ & $\frac{37.36}{9.1}$ & 9.1 \\
ER-EC-2 & 4.1 & 19.88 & 20.88 & 5.1 \\
ER-12-1 & 0.2 & 0.97 & 1.97 & 0.5 \\
ER-9-1 & 3.6 & 17.46 & 18.46 & 4.5
\end{tabular}

\section{E3.0 TOTAL EMISSIONS DURING OPERATIONS}

\section{E3.1 UNPAVED ROAD TRAVEL}

Assume: Ten vehicles per 8-hour shift for 50 workdays ( 25 days of well drilling, 25 days of well testing).

Then:

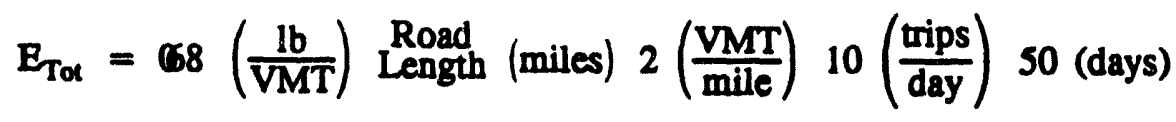

gives the following table of TSP emissions for unpaved road travel during the operational period:

\begin{tabular}{lcrc} 
Site & $\begin{array}{c}\text { Road } \\
\text { Length } \\
\text { (miles) }\end{array}$ & \multicolumn{2}{c}{ Total TSP Emissions } \\
\cline { 4 - 4 } ER-19-1 & 7.5 & $\frac{(\text { lb) }}{\text { (tons) }}$ & $\frac{1.100}{2.55}$ \\
ER-EC-2 & 4.1 & 2,788 & 1.39 \\
ER-12-1 & 0.2 & 136 & 0.07 \\
ER-9-1 & 3.6 & 2,448 & 1.22
\end{tabular}




\section{E3.2 WIND EROSION}

Assume: 1. Area subject to wind erosion is 1.0 acres of pad plus sump area, plus road area according to road length.

2. Operational period is 10 weeks (70 days, or 50 workdays).

Then:

$$
\mathrm{E}_{\text {Ta }}=16.6\left(\frac{1 \mathrm{~b}}{\text { acre }- \text { day }}\right) 70 \text { (days) } \underset{\text { Actes }}{\text { Tacres) }} \frac{1}{2,000}\left(\frac{\text { tons }}{1 b}\right)
$$

and total acres for each site based on a road width of 40 feet gives the following table of wind erosion TSP emissions:

\begin{tabular}{lcccc} 
Site & $\begin{array}{c}\text { Road } \\
\text { Length } \\
\text { (miles) }\end{array}$ & $\begin{array}{c}\text { Road } \\
\text { Area } \\
\text { (acres) }\end{array}$ & $\begin{array}{c}\text { Total } \\
\text { Area } \\
\text { (acres) }\end{array}$ & $\begin{array}{c}\text { TSP } \\
\text { Emissions } \\
\text { (tons) }\end{array}$ \\
\hline ER-19-1 & 7.5 & $\frac{36.36}{37.36}$ & 21.1 \\
ER-EC-2 & 4.1 & 19.88 & 20.88 & 11.8 \\
ER-12-1 & 0.2 & 0.97 & 1.97 & 1.1 \\
ER-9-1 & 3.6 & 17.46 & 18.46 & 10.4
\end{tabular}

\section{E3.3 DIESEL EQUIPMENT}

Assume: 1. The following equipment mix for the drilling portion of the operational phase:

\begin{tabular}{|c|c|c|}
\hline Equipment & Number & $\begin{array}{c}\text { Rated } \\
\text { Horse Power }\end{array}$ \\
\hline Drill Rig & 1 & 530 \\
\hline Air Compressors & 2 & 970 (485 eact \\
\hline Mud Pump & 1 & 485 \\
\hline Sump Pump & 1 & 99 \\
\hline $330 \mathrm{KW}$ Generator & 1 & 485 \\
\hline $\begin{array}{l}40 \mathrm{KW} \text { Generator } \\
\text { TOTAL HORSI }\end{array}$ & 1 & $\frac{80}{2,649}$ \\
\hline
\end{tabular}

2. Continuous full-power operation 24 hours/day for $\mathbf{2 5}$ days (upper limit assumption) for the drilling portion of the operational phase.

Then:

$$
\begin{gathered}
\mathrm{E}_{\mathrm{Ta}}=\underset{\text { Factor }}{\text { Emission }}\left(\frac{\mathrm{g}}{\mathrm{hp}-\text { hour }}\right) 2,649 \text { (hp) } 25 \text { (days) } 24\left(\frac{\text { hours }}{\text { day }}\right) \\
\frac{1}{454}\left(\frac{\mathrm{g}}{\mathrm{lb}}\right) \frac{1}{2,000}\left(\frac{\text { ton }}{\mathrm{lb}}\right)
\end{gathered}
$$


with emission factors given in Section E1.4, gives the following emissions for the drilling portion of the operational phase:

\begin{tabular}{ccc} 
Pollutant & $\begin{array}{c}\text { Emission } \\
\text { Factor } \\
\text { (g/hp-hour) }\end{array}$ & $\begin{array}{c}\text { Total } \\
\text { Emissions } \\
\text { (tons) }\end{array}$ \\
\cline { 3 - 4 } CO & 3.03 & 5.30 \\
$\mathrm{NO}_{\mathrm{x}}$ & 14.00 & 24.51 \\
$\mathrm{SO}_{\mathrm{x}}$ & 0.931 & 1.63 \\
$\mathrm{TSP}$ & 1.00 & 1.75
\end{tabular}

The drilling portion of the operational phase would be followed by 25 days of testing, during which a 300-HP workover rig would be used. For the testing portion of the operational phase,

Assume: A 300-HP diesel engine would be in operation for 25 eight-hour days.

Then:

$$
\begin{aligned}
& E_{T \alpha}=\underset{F a c t o r}{\text { Emission }}\left(\frac{g}{\text { hp }- \text { hour }}\right) 300 \text { (hp) } 25 \text { (days) } 8\left(\frac{\text { hours }}{\text { day }}\right) \\
& \frac{1}{454}\left(\frac{1 b}{8}\right) \frac{1}{2,000}\left(\frac{t o n}{1 b}\right)
\end{aligned}
$$

with the same emission factors as above, gives the following total diesel equipment emissions for

\begin{tabular}{|c|c|c|}
\hline Pollutant & $\begin{array}{c}\text { Emission } \\
\text { Factor } \\
\text { (g/hp-hour) } \\
\end{array}$ & $\begin{array}{c}\text { Total } \\
\text { Emissions } \\
\text { (tons) } \\
\end{array}$ \\
\hline $\mathrm{CO}$ & 3.03 & 0.20 \\
\hline $\mathrm{NO}_{\mathrm{x}}$ & 14.00 & 0.93 \\
\hline $\mathrm{SO}_{x}$ & 0.931 & 0.06 \\
\hline TSP & 1.00 & 0.07 \\
\hline
\end{tabular}
the testing portion of the operational phase:

Combining emissions from the drilling and testing portions of the operational phase gives the following table of total diesel equipment emissions during the operational phase:

\begin{tabular}{cr} 
Pollutant & $\begin{array}{c}\text { Total } \\
\text { Emissions } \\
\text { (tons) }\end{array}$ \\
\cline { 3 - 3 } $\mathrm{CO}$ & 5.50 \\
$\mathrm{NO}_{\mathrm{x}}$ & 25.44 \\
$\mathrm{SO}_{\mathrm{x}}$ & 1.69 \\
$\mathrm{TSP}$ & 1.82
\end{tabular}




\section{EA.0 TOTAL ANNUAL EMISSIONS AFTER COMPLETION OF WELL DRILLING AND TESTING}

Assume: 1. After all operational activities, emissions would be solely particulate emissions from wind erosion.

2. Area subject to wind erosion is 1.0 acres of pad plus sump area, plus road area according to road length.

Then:

$$
E_{\text {Ta }}=166\left(\frac{1 b}{a c r e-d a y}\right) 365 \text { (days) } \underset{\text { Acres }}{\text { Toral }} \text { (acres) } \frac{1}{2,000}\left(\frac{\text { tons }}{1 \mathrm{~b}}\right)
$$

with total acres for each site based on a road width of 40 feet, gives the following table of annual TSP emissions due to wind erosion:

\begin{tabular}{|c|c|c|c|c|}
\hline Site & $\begin{array}{c}\text { Road } \\
\text { Length } \\
\text { (miles) }\end{array}$ & $\begin{array}{c}\text { Road } \\
\text { Area } \\
\text { (acres) }\end{array}$ & $\begin{array}{c}\text { Total } \\
\text { Area } \\
\text { (acres) }\end{array}$ & $\begin{array}{c}\text { TSP } \\
\text { Emissions } \\
\text { (tons) }\end{array}$ \\
\hline ER-19-1 & 7.5 & 36.36 & 37.36 & 110.2 \\
\hline ER-EC-2 & 4.1 & 19.88 & 20.88 & 61.6 \\
\hline ER-12-1 & 0.2 & 0.97 & 1.97 & 5.8 \\
\hline ER-9-1 & 3.6 & 17.46 & 18.46 & 54.4 \\
\hline
\end{tabular}

\section{E5.0 CONCENTRATION ESTIMATES}

\section{E5.1 METHOD}

Contributions to ambient concentrations from GCP activities were estimated with the ISCST model. The ISCST model is a Gaussian plume model for estimating multiple-hour average concentrations from point, area, and volume sources in flat to gently rolling terrain. It is applicable to the GCP assessment because emissions are close to ground level and, in the case of fugitive dust, non-buoyant so that maximum concentrations occur near the source. ISCST uses hourly meteorological data and emission rates and receptor data that include coordinates, elevations, and height above ground for simulated receptors.

For this application, hourly meteorological data from the Desert Rock Weather Service Meteorological Observatory (WSMO) for the complete Calendar Year 1986 were used, with hourly mixing heights based on twice-daily soundings also made at Desert Rock. The Desert Rock WSMO is located near Mercury, at the southern edge of the NTS. Representativeness of Desert Rock data for GCP well sites is variable from site to site and depends upon local exposure. However, for this generic study, one year of Desen Rock data should give a reasonable estimate for 
worst-case conditions that could occur at any specific site, especially for a flat-terrain approximation with maximum concentrations at receptors close to the source.

Simulated receptors were organized in a $2 \mathrm{~km} \times 2 \mathrm{~km}$ Cartesian grid, with a receptor spacing of $100 \mathrm{~m}$. This resulted in a total of 440 receptors extending to $1 \mathrm{~km}$ from the origin in each of the cardinal directions. Receptor elevations were the same as source elevations, i.e., flat terrain was simulated, and each receptor was given a height of $2 \mathrm{~m}$ above ground level in the "breathing zone".

Construction and wind erosion fugitive dust sources were simulated as area sources centered at the grid origin, with an effective emission height of $10 \mathrm{~m}$ above ground level and temperatures of $293^{\circ} \mathrm{K}$ to approximate the ambient temperature. Heavy equipment and diesel-fueled equipment were simulated as combined single point sources with emission heights of $5 \mathrm{~m}$ above ground level and temperatures of $400^{\circ} \mathrm{K}$. Calculations of emission rates for these sources are detailed below.

\section{E5.2 SCENARIOS}

Three scenarios were modeled; two scenarios to estimate maximum short-term (24 hours or less) contributions that could result from construction-phase activities and from operational-phase (well-drilling) activities, and one scenario to estimate maximum annual average contributions resulting from wind erosion of exposed surfaces.

\section{E5.2.1 Construction Phase}

Three sources were simulated for the construction phase:

1. Construction Dust - simulated as an area source with dimensions $69.7 \mathrm{~m}$ by $69.7 \mathrm{~m}(1.2$ acres, 0.5 hectares) for the pad plus sump pit area ( 1.0 acres) and nearby access road area ( 0.2 acres). This was meant to represent maximum adjacent the total area under construction on any given day. The emission rate for this source in $\mathrm{g} / \mathrm{m}^{2} / \mathrm{sec}$, with watering for 50 percent control efficiency, was estimated from the basic emission factor for construction activities (Equation 1) averaged over 22 eight-hour days per month during the construction period as follows.

$$
\begin{aligned}
Q= & R\left(\frac{\text { tons }}{\text { acre }- \text { month }}\right) \frac{1}{22}\left(\frac{\text { months }}{\text { day }}\right) R \text { (acres) } \frac{1}{8}\left(\frac{\text { days }}{\text { hour }}\right) 2,000\left(\frac{\mathrm{lb}}{\text { ton }}\right) \\
& 454\left(\frac{g}{\mathrm{lb}}\right) \frac{1}{3,600}\left(\frac{\text { hour }}{\mathrm{sec}}\right) \frac{50}{100}(\%) \frac{1}{4,856}\left(\frac{1}{\mathrm{~m}^{2}}\right)=2 \times 10^{-4} \mathrm{~g} / \mathrm{m}^{2} / \mathrm{sec}
\end{aligned}
$$

This emission rate was assumed to occur during the hours of 0800 to 1700 , and was zero otherwise. 
2. Heavy Equipment Exhaust - emissions from 2 dozers, 2 scrapers, 2 blades, 2 water trucks, and 1 roller/compactor were simulated as a single point source at the grid origin. The emission rate for this source, in $\mathrm{g} / \mathrm{sec}$, was calculated by:

$$
Q=\underset{\text { Factor }}{\text { Emission }}\left(\frac{\mathrm{lb}}{\text { hour }}\right) 454\left(\frac{\mathrm{g}}{\mathrm{lb}}\right) \frac{1}{3.600}\left(\frac{\text { hour }}{\mathrm{sec}}\right)
$$

With combined emission factors given in Section E1.3, resulting emission rates for this source were as follows:

\begin{tabular}{|c|c|c|}
\hline Pollutant & $\begin{array}{c}\text { Emission } \\
\text { Factor } \\
\text { (lb/hour) } \\
\end{array}$ & $\begin{array}{c}\text { Emission } \\
\text { Rate } \\
(\mathrm{g} / \mathrm{sec}) \\
\end{array}$ \\
\hline $\mathrm{CO}$ & 10.14 & 1.28 \\
\hline $\mathrm{NO}_{\mathrm{x}}$ & 26.48 & 3.34 \\
\hline $\mathrm{SO}_{\mathrm{x}}$ & 2.79 & 0.35 \\
\hline TSP & 1.84 & 0.23 \\
\hline
\end{tabular}

These emission rates were assumed to occur during the hours 0800 to 1700 , and were zero otherwise.

3. Wind Erosion - simulated as the same size area source as the Construction Dust source. The TSP emission rate, in $\mathrm{g} / \mathrm{m}^{2} / \mathrm{sec}$, was calculated by averaging the daily emission factor given in Section E1.5 over 24 hours per day, as follows:

$$
\begin{aligned}
Q= & 166\left(\frac{\mathrm{lb}}{\text { acre }- \text { day }}\right) \frac{1}{24}\left(\frac{\text { days }}{\text { hour }}\right) \frac{1}{3,600}\left(\frac{\text { bours }}{\mathrm{sec}}\right) 454\left(\frac{\mathrm{g}}{\mathrm{lb}}\right) \\
& \text { D (acres) } \frac{1}{4,856}\left(\frac{1}{\mathrm{~m}^{2}}\right)=2 \times 10^{-5} \mathrm{~g} / \mathrm{m}^{2} / \mathrm{sec}
\end{aligned}
$$

\section{E5.2.2 Operational Phase}

During the operational phase, there would be no construction dust. A single point source was used in this scenario to represent combined emissions from diesel equipment with total power rating of $2,164 \mathrm{hp}$, the same as the mix given in Section $\mathrm{E} 3.3$ but with only one air compressor. For upper-limit estimates, it was assumed that this equipment is in continuous full power operation 24 hours per day during the well drilling portion of the operational phase. The resulting point source emission rates, in $\mathrm{g} / \mathrm{sec}$, were estimated from:

$$
Q=\underset{\text { Factor }}{\text { Emission }}\left(\frac{\mathrm{g}}{\mathrm{hp}-\text { hour }}\right) 2,164(\mathrm{hp}) \frac{1}{3,600}\left(\frac{\text { hour }}{\mathrm{sec}}\right)
$$

With diesel-fueled equipment emission factors given in Section E1.4, the resulting point source emission rates were as follows: 


$\begin{array}{ccc}\text { Pollutant } & \begin{array}{c}\text { Emission } \\ \text { Factor } \\ \text { (g/hp-hour) }\end{array} & \begin{array}{c}\text { Emission } \\ \text { Rate } \\ (\mathrm{g} / \mathrm{sec})\end{array} \\ \mathrm{CO} & 3.03 & 1.82 \\ \mathrm{NO}_{\mathrm{x}} & 14.00 & 8.42 \\ \mathrm{SO}_{\mathrm{x}} & 0.931 & 0.56 \\ \mathrm{TSP} & 1.00 & 0.60\end{array}$

\section{E5.2.3 Annual Wind Erosion}

The hourly emission rate used to estimate anmual average TSP contributions from wind erosion was based on a representative exposed area of 1.2 acres. The resulting emission rate, in $\mathrm{g} / \mathrm{m}^{2} / \mathrm{sec}$, was estimated as:

$$
\begin{aligned}
Q= & 166\left(\frac{1 \mathrm{~b}}{\text { acre }- \text { day }}\right) \frac{1}{24}\left(\frac{\text { days }}{\text { hour }}\right) \frac{1}{3,600}\left(\frac{g}{\mathrm{lb}}\right) \\
& 454\left(\frac{\mathrm{g}}{\mathrm{Ib}}\right) \text { D (acres) } \frac{1}{4,856}\left(\frac{1}{\mathrm{~m}^{2}}\right)=21 \times 10^{-5} \mathrm{~g} / \mathrm{m}^{2} / \mathrm{sec}
\end{aligned}
$$

\section{E5.3 RESULTS}

Results from ISCST modeling of the above scenarios are given in the following tables. 
Maximum Short-Term Contributions for Construction Phase

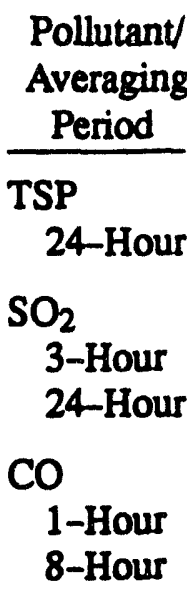

Pollutant/

Averaging
Contribution

$\left(\mu \mathrm{g} / \mathrm{m}^{3}\right)$

138

452

100

4,960

1,092
Receptor Coordinates

(m) (m)

$-100 \quad-100$

$100 \quad 0$

1000

$100 \quad 0$

$100 \quad 0$

Maximum Short-Term Contributions for Operational Phase (Well-Drilling)

\begin{tabular}{|c|c|c|c|}
\hline \multirow{2}{*}{$\begin{array}{c}\text { Pollutant/ } \\
\text { Averaging } \\
\text { Period } \\
\end{array}$} & \multirow[b]{2}{*}{$\begin{array}{c}\text { Contribution } \\
\left(\mu g / \mathrm{m}^{3}\right) \\
\end{array}$} & \multicolumn{2}{|c|}{ Receptor Coordinates } \\
\hline & & $\begin{array}{c}x \\
(m) \\
\end{array}$ & $\begin{array}{c}y \\
(m) \\
\end{array}$ \\
\hline $\begin{array}{l}\text { TSP } \\
\text { 24-Hour }\end{array}$ & 162 & 100 & 0 \\
\hline $\begin{array}{l}\mathrm{SO}_{2} \\
3 \text {-Hour } \\
\text { 24-Hour }\end{array}$ & $\begin{array}{l}810 \\
151\end{array}$ & $\begin{array}{r}-100 \\
100\end{array}$ & $\begin{array}{r}100 \\
0\end{array}$ \\
\hline $\mathrm{CO}$ & & & \\
\hline $\begin{array}{l}\text { 1-Hour } \\
\text { 8-Hour }\end{array}$ & $\begin{array}{l}6,042 \\
1,152\end{array}$ & $\begin{array}{r}-100 \\
0\end{array}$ & $\begin{array}{r}0 \\
-100\end{array}$ \\
\hline
\end{tabular}

Maximum Annual Average TSP Concentration

(Wind Erosion)

Pollutant/

Averaging

Period

TSP

24-Hour
Contribution

$\left(\mu \mathrm{g} / \mathrm{m}^{3}\right)$

2.4 $\frac{\text { Receptor Coordinates }}{\mathrm{x}}$

(m) (m)

$-100 \quad-100$ 


\title{
NEVADA OPERATIONS OFFICE
}

\section{GROUNDWATER CHARACTERIZATION PROJECT MITIGATION ACTION PLAN}

\author{
December 1, 1993 Revision
}

\section{Introduction}

The Department of Energy, through its Nevada Operations Office (DOE/NV), proposed the Groundwater Characterization Project (GCP) to characterize the groundwater flow system of the Nevada Test Site (NTS) by drilling and monitoring roughly 100 (90 to 120) deep wells. The GCP was implemented in Fiscal Year 1992 (FY 92) and drilling activities will last approximately 9 to 10 years, producing 6 to 17 wells per year. Groundwater monitoring commences at the completion of each well and continues through the life of the project. DOE/NV has direct control of the GCP and IT Corporation provides environmental support services. IT Corporation and Desert Research Institute (DRI), in conjunction with a working group composed of representatives from the US Geological Survey, and the Lawrence Livermore and Los Alamos National Laboratories supply the scientific expertise and technical guidance for the project.

The DOE/NV's policy is to make environmental preservation and restoration an integral part of all its activities. The alternatives and environmental effects of this project were analyzed in an environmental assessment (EA) (DOE/EA-0532). Because this project is, of necessity, an iterative process, with each phase being dependent upon findings derived from the preceding phases, exact locations have not been chosen for wells to be installed in the later stages of this project. Consequently, the EA analyzed geographical groupings of wells in the context of what resources may be encountered within known geographic areas. The EA identified potential impacts to biological and cultural resources. It also developed the means to identify and avoid potential impacts, or to mitigate them to insignificant levels. Due to the reliance of this project on effective and well implemented mitigation measures to ensure insignificant environmental effects, DOE has prepared this Mitigation Action Plan in accordance with the DOE NEPA regulations (10 CFR Part 1021). The EA contains detailed information regarding resources present, potential adverse environmental effects, and the mitigation measures necessary to ameliorate these effects. These details are not repeated in this plan, but are incorporated by reference.

\section{Responsibility}

Overall responsibility for the environmental and safety integrity of this project lies with DOE/NV. The Environmental Protection Division (EPD) provides advice and recommendations on technical and regulatory issues relating to environmental protection and compliance. The Nevada Test Site Office (NTSO) is responsible for the day-to-day operational aspects at NTS, while each contractor organization is responsible for discharging its particular duties and functions. The GCP Project Manager (PM) is on the staff of the 
Environmental Restoration Division (ERD), a unit within DOE/NV's Assistant Manager for Environmental Restoration and Waste Management (AMEM) organization. The Division is responsible for assisting the $P M$ in identifying the environmental requirements which must be met for each site or activity. The PM is responsible for timely identification of proposed well locations. ERD and EPD staffs are responsible for determining which preactivity surveys are required and for scheduling these surveys. EPD staff will direct DRI (cultural resources) and EG\&G (biological resources) to conduct the surveys and write the reports. ERD personnel will coordinate with project scientists, archaeologists and biologists to ensure avoidance of conflicts with important resources wherever possible. Where complete avoidance is not possible, ERD will consult appropriate sources and determine what actions are necessary to comply with agreements with the State Historic Preservation Officer (SHPO) or with the U.S. Fish and Wildlife Service (FWS). ERD will include these requirements in the Criteria Letters which authorize NTSO to commence work on the projects.

ERD will be responsible for ensuring that project biological surveys are current. Currency in biological surveys is governed by the specific resources at risk, their mobility, and the likelihood of their invasion of the site. This time frame will be established by ERD in consultation with EG\&G biologists. ERD and EPD will conduct periodic field surveillances to evaluate the implementation and effectiveness of the mitigation measures. ERD will write an annual report which summarizes the GCP activities for the reporting period and analyzes the results of various monitoring and surveillance activities pertaining to the GCP. EPD will conduct surveillances to determine overall compliance with environmental and permit requirements. Reynolds Electrical and Engineering Company (REECo) Environmental Compliance Office (ECO) conducts inspections of activities for compliance with permit and other legal requirements. Quality assurance reviews are performed periodically by the Quality Assurance staff to evaluate adherence to established procedures and orders.

\section{Reporting}

ERD will be responsible for writing an annual report which will be distributed by ERD to all participating organizations and to the Assistant Secretaries for Environmental Restoration and Waste Management and for Environment, Safety and Health at DOE Headquarters. This report will summarize GCP activities during the previous year including the total acreage disturbed by the GCP and the results of monitoring and surveillances. The report will also provide an assessment of the effectiveness of mitigation measures taken during the previous year. If mitigation measures are found by ERD to be ineffective, then revisions or studies necessary to make them effective will be outlined. The report will also assess whether any mitigation measures are no longer warranted due to their ineffectiveness or to changed conditions. Changes necessitated by new or revised programmatic, interagency or other agreements will be planned and outlined in the report. 


\section{Mitigation Actions and Effectiveness Monitoring Criteria}

Mitigation for purposes of this Mitigation Action Plan includes procedures to avoid or offset adverse effects on plant and animal species of concern, historic and prehistoric cultural resources, and Native American traditional cultural resources, including sacred sites.

\section{Biological Resources (EA Sec. 4.6)}

Vegetation (EA Sec.4.6.1)

Areas of previous disturbance will be utilized whenever possible unless the PM judges that would create greater damage. Surface disturbance will be minimized as much as possible for road and pad construction. Reclamation will be conducted where feasible and will include reestablishment of productive native vegetation.

Biological preactivity surveys will identify unique plants such as cacti, yuccas and Joshua trees. Such plants will be flagged in the field and mapped, as is done with sensitive species. Recommendations will be made in the preactivity survey reports with the intent to preserve the plants if possible.

\section{Wildlife (EA Sec.4.6.2)}

Features such as predator burrows will be identified through the process of preactivity surveys and reports. Instructions will be put into criteria letters to avoid or protect these features whenever it is possible to do so and still accomplish the GCP scientific objectives. Preactivity survey reports will be reviewed for selected drill sites to determine if these features were present and if they were protected during construction and operations. The measure will be successful if an identified feature was protected as directed in the criteria letter.

Sensitive Species (EA Sec. 4.6.3)

\section{Candidate Species}

There are a number of plant species that are candidates for listing under the Endangered Species Act (ESA), that may occur on or near the proposed well sites. Although candidate species are not formally protected under the ESA, DOE policy specifies that preactivity surveys be performed on all proposed construction sites or areas of surface disturbance in the event that these species may become listed in the future. Each survey will be conducted by qualified professionals. Surveys will be made to ensure 100 percent coverage of the project area itself, plus a suitable buffer, the size of which is dependant on the nature of the proposed activity. The intent of the buffer is twofold; first, it allows repositioning of the disturbed area if a conflict is found in the original area and, second, it allows for contingency planning to avoid adverse effects on significant resources in the buffer zone. 
Locations of all sensitive plant habitats will be flagged in the field; the survey report will include mapped and descriptive locations as well as recommendations for protection. If a proposed location is expected to be in close proximity to a population falling in this category, biologists would accompany GCP personnel to aid in efficiently locating the site so as to avoid or minimize impacts.

All preactivity survey reports will be reviewed by the ERD staff to ensure that the Criteria Letters, which are sent to NTSO to authorize project starts and identify the requirements and constraints bounding the project, contain all appropriate mitigation requirements. Preactivity survey reports will be consulted and field inspections will be conducted by ERD on a periodic basis to determine if the area of disturbance has been confined to the area approved and staked and if there have been effects within the buffer zone. These measures will be judged effective if the majority of the identified plants have been saved or if no candidate species plants have been lost.

Threatened Species

\section{Desert Tortoise}

Desert tortoises are found throughout the southern one-third of the NTS. The abundance of desert tortoises on the NTS is low to very low relative to other areas within this species' range in southern Nevada.

A Biological Assessment (BA) of the Effects of Activities of the U. S. Department of Energy Nevada Field Office on the threatened desert tortoise has been prepared by DOE and submitted to the FWS for formal Section 7 consultation under the Endangered Species Act. This BA includes most ongoing and planned activities that will occur on the NTS through fiscal year 1995 that may impact desert tortoises, including the GCP. A Biological Opinion (BO) was received from the FWS in May 1992. In that Opinion, a "no jeopardy" determination was made by the FWS i.e., that the proposed action will not jeopardize the continued existence of a threatened or endangered species or its habitat.

No wells are expected to be drilled within tortoise habitat until 1996. Thus either an extension of the present BO or a new BO covering the activities subsequent to FY 1995 may apply. This Mitigation Action Plan will be revised to include specific tortoise protective measures, if any, included in the applicable BO.

\section{Historic and Cultural Resources (EA Sec. 4.7)}

Historic and cultural resources are managed and protected by different procedures and agreements depending upon their location. Areas on Pahute and Rainier Mesas are covered by a Programmatic Agreement (PA) among DOE/NV, the Nevada State Historic Preservation Officer (SHPO), and the Advisory Council on Historic Preservation (ACHP). A PA has been consummated between the Yucca Mountain Project Office (YMPO) and 
the ACHP to cover YMPO site characterization activities. For off-NTS locations, coordination is required with the Bureau of Land Management (BLM) on public lands, and the BLM and Air Force on USAF withdrawn lands. Survey reports and data will be provided to the BLM and USAF as appropriate.

In response to the mesa PA requirements, a Long Range Study Plan (LRSP) for the mesas was prepared. The LRSP identifies sample units within which data recovery is required if any activity is proposed which may affect the unit's cultural resources. The PA also requires that surveys be conducted to find and protect historic resources which may occur outside of the sample units.

For non-mesa areas, cultural resource surveys would be completed and evaluations will be made to determine whether or not the site(s) is (are) potentially eligible for the National Register of Historic Places. If eligible, the first priority for mitigation would be avoidance. If avoidance is not possible, then data recovery would be required to mitigate the effect. DOE will coordinate with the SHPO in regard to the survey, the eligibility determination and the data recovery plan.

On off-NTS locations, preactivity surveys will be done to identify the nature and extent of cultural resources present. Appropriate site-specific mitigation measures will be developed in coordination with the land managing agency and the SHPO. These measures will specify avoidance of cultural resource sites as a first priority.

ERD and EPD will ensure that surveys are completed in areas where they are required. In data recovery sample units, ERD and EPD will ensure that data recovery is accomplished. ERD receives copies of the survey reports and recommendations and will specify in Criteria Letters what protection or mitigation measures will be implemented. No letter will be issued authorizing the start of activities that may affect the resource until all appropriate mitigation measures such as data recovery have been completed in the areas affected.

EPD will review its correspondence files, its lists of completed preactivity survey reports, and its SHPO coordination records to determine if the appropriate compliance procedures have been adhered to. These would include coordination with the SHPO and ACHP and the transmission of required reports to the agencies. Where either listed or eligible National Register of Historic Places sites are involved, EPD will ensure that an evaluation is conducted to determine if there has been an effect. These mitigation measures will be judged successful if coordination has been done and if there has not been a significant effect on the site. For locations in off-NTS areas, review will be done to determine if preactivity surveys and reports have been completed, and if proper coordination with the BLM and SHPO have been completed. If data recovery has been done, then a review of why the site was not avoided will be completed. Selected buffer zones will monitored to determine if an impact has occurred to sites in the buffer. These measures will be judged successful if proper coordination and consultation have been completed or if data recovery was 
conducted for reasons which are supportable either as technical or scientific requirements of the GCP. If no more than minor effects in the buffer zone occurred, then these measures will be judged successful. ERD, in conjunction with EPD, will be responsible for conducting the evaluation using contractor support for the field evaluation. 
. 